\title{
NAZAR İYAT
}

\section{Touching the Point: Mu'ayyadzāda 'Abd Al-Rahmmān Efendi's Treatise on Juz' Alladhì Lā Yatajazza': An Analysis, Critical Edition, and Translation*}

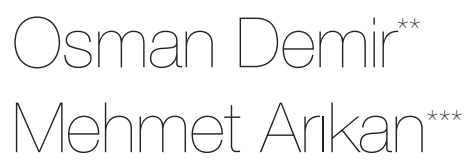

\begin{abstract}
This article provides the analysis, translation, and critical edition (tahquĩ) of Mu'ayyadzāda 'Abd al-Raḥmān Efendi's (d. 922/1516) treatise on al-juz' alladhì lā yatajazza' (Treatise on the indivisible part), which is important in the debates of atomism in the history of Islam. If the subject and the method of the risāla is taken into consideration, one can regard it as a continuation of the tradition of the Sharh alMawāqif glosses. After a brief discussion in the article's introduction related to the importance of the work and its topic, the copies of the manuscripts that contributed to this critical edition process, as well as the risāla's ownership, will be presented. The section on content analysis is divided mainly into three parts. The first one (a) summarizes the problem of contiguity (tamāss) faced by the author to inform the readers of its background. The following sections that focuses directly on the risāla's content is (b) an overview of the eighty geometrical proofs set by the author to cancel the idea of contiguity's survival in time (baqä altamāss) in the Avicennian concept, and (c) focusing on the "well-known doubt" (al-shubhat al-mashhüra), which examines the time-instant relationship in the context of how the sphere touches the surface. The article's analytical section ends with the conclusion and the bibliography, including the critical edition, based upon the four copies of the risäla and its translation.
\end{abstract}

Key Words: Mu'ayyadzāda 'Abd al-Rahmmān Efendi, Atomism, Hylomorphism, Theology, Islamic Philosophy, Ottoman Intellectual Thought, Problem of Contiguity, Time and Instant Relationship.

\footnotetext{
* We express our gratitude to M. Zahit Tiryaki, Ali Aslan, and Selman Sucu, all of whom helped compare the treatise's different copies, and to Muhammed Ali Koca, who read the entire edited text and shared his suggestions with us, and to the anonymous referees who contributed to the treatise with their proposals.

** Assoc. Prof. Ankara Hacı Bayram Veli University Polatlı Divinity Faculty \& University of Bonn, Alexander von Humboldt Kolleg for Intellectual History. Correspondence: demirosman1974@gmail.com

*** Res. Assist., İstanbul Medeniyet University, Department of History of Sciences.Correspondence: mehmet280@gmail.com
} 


\section{Introduction}

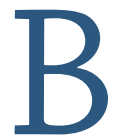

eginning from the first period before al-Ghazālī, the mutakallimūn's understanding of nature was largely represented by the theory of al-jawhar al-fard (single atom). Accordingly, the universe consists of parts (juz' alladhi lā yatajazza') that cannot be divided and attributes ( $a^{\prime} r a \bar{d}$ ) inhered on them, and the association of these things forms the body and the material world. These similar, non-renewable, and homogenous parts, none of which have a mental existence, have an assumed place (hayyiz), surfaces, and volumes (masāha), although they have no dimensions and primary qualities. One part joins the other parts to form the line, the lines are combined to form the surface, and the overlapping of the two surfaces forms a finite and limited body divided in terms of length, width, and depth. In this respect, it is assumed that physical elements such as time, space, movement, distance, and direction come together at the conjunction of the parts. These parts are, first and foremost, created by the direct creation of a God from nothing, but also continue to exist by His constant creation of the matter contained in a substance. At this time, the mutakallimūn did not solve just the problems that emerged while struggling with dualist and materialist trends and then with the philosophers in the framework of the relationship of God-universe, but they also explained many of the creedal subjects, including prophethood, human deeds, and corporeal resurrection in the afterlife, in a way that was compatible with the views of revelation. ${ }^{1}$

By the end of the first period, the interest in the theory of al-jawhar al-fard seems to have lost its influence; however, a new atomist model was built during the period that began with Fakhr al-Dīn al-Rāzī (d. 606/1210). In this new model, the concept of the part, which was at the core of the theory, also underwent a certain transformation. The idea of representing the part by a geometrical point, which had been the case during the first period, was now supported by philosophical knowledge and ontology and became a part of the search for existence. This theory was further fortified by assimilating some of the features of the theory of matter and form. While the issues related to theoretical physics were discussed in detail within the jawhar and a'räḍ chapters, the science of kalām strengthened its scientific identity even further. The adoption of results and debates that emerged

1 Alnoor Dhanani, The Physical Theory of Kalām: Atoms, Space and Void in Basrian Mu'tazilì Theology (Leiden: Brill, 1994). Munā Aḥmad Muhammad Abū Zayd, al-Tasawwur al-Dharrī fì al-Fikr al-Falsafī al-Islāmī (Beirut: al-Mu’assasāt al-Jāmi'iyya, 1994). Mehmet Bulğen, Kelam Atomculuğu ve Modern Kozmoloji (Ankara: Türkiye Diyanet Vakfı, 2015). Shlomo Pines, İslâm Atomculuğu, trans. Osman Demir (Istanbul: Klasik Yayınları, 2017). 
with al-Rāzī's philosophical criticism of the period's important names underwent different conceptual transformations and problems during this process. ${ }^{2}$ As a result, independent treatises were written in order to solve the new problems that arose. Therefore, this treatise should be seen as a continuation of that process.

Sharh al-Mawāqif is one of the strongest opuses that contains theoretical physics among the kalām works. Its matters were subjected to various glossaries afterward. Even though the super-commentators (muhashshī) were more likely to concentrate on the chapter of general matters (al-umūr al-'ämma), some of the points in the jawhar and a'räd chapters were also interesting. Therefore, some works contained mutual subjects, concepts, and references. The topics were examined discursively in voluminous works in the chapter on physics, after which scrutinized independent articles and problems began to crystallize gradually. Mu'ayyadzāda's (d. 922/1516) $)^{3}$ treatise, which we are analyzing here, is a critical edition, translation and analyze is a part of the literature devoted to the studies of atomism, taking into account the methodology and the frame of its reference. An author begins treatise with a quotation from al-Mawāqif, investigates the proof of contiguity that the mutakallimūn and falāsifa used to prove their own theories and the extended engaged issues such as time, space and distant in a structure both propose to overcome the existing problems and moving from the historical accumulation. ${ }^{4}$

Al-İjì's definition of body can be given an example of that transformation: "The object is an entity consisting of al-jawhar al-fard, which has space and dimension and also accepts the division." 'Adūd al-Dīn al-İjī, Kitāb al-Mawāqif (with Sharḥ al-Mawāqif) ed. 'Abd al-Raḥmān 'Umayra, 1-3 (Beirut: Dār al-Jìl, 1417/1997), 2, 315. Also see Osman Demir, "Îcî Kelâmında Fizik," İslâm İlim ve Fikir Geleneğinde Adudüddin el-Îcî, ed. Eşref Altaş (Istanbul: İSAM Yayınları 2017), 333-84.

3 To obtain general knowledge about Mu'ayyadzāda's life, Taşköprīzāde Aḥmad Efendi, al-Shaqā’iq alNu'māniyya fì 'Ulamā' al-Dawlat al-'Uthmāniyya (Beirut: Dār al-Kitāb al-'Arabī, 1395/1975), 176-79. Mahmūd b. Sulaymān al-Kafawī, Katāỉbu A'Tām al-Ahyār min Fuqahā'i Madhhab al-Nu'mān al-Mukhtār, ed. Saffet Köse, Murat Şimşek, Hasan Özer, Huzeyfe Çeker, and Güneş Öztürk (Istanbul: Maktabat alIrshād, 1438/2017), 4, 419-24. İsmail Hakkı Uzunçarşıll, Osmanlı Tarihi (Ankara: Türk Tarih Kurumu Basımevi, 1949), 2, 657-60. M. Tayyib Gökbilgin, "Müeyyed-zâde”, İA, 8, 786-90. Hasan Aksoy, "Müeyyedzâde Abdurrrahman Efendi," DİA, 31, 485-86. Ahmet İnanır, "Müeyyedzâde Abdurrahman Efendi'nin Hayatı ve Osmanlı Hukuk Geleneğindeki Yeri," Uluslararası Amasya Âlimleri Sempozyumu Bildiriler Kitabı, ed. Şuayip Özdemir and Ayşegül Gün (Ankara: Amasya Üniversitesi İlahiyat Fakültesi, 2017), 1, 339-47.

4 Mu'ayyadzāda wrote three Hāshiya on Sharh al-Mawāqif. The first one is dedicated to Bayezid II, namely, Hâshiya 'alā Sharh al-Mawāqif. A master thesis was completed on this treatise, which deals with the divine attributes. See Moulay el-Hassen el-Hafīdī, "Müeyyedzâde b. Ali'nin el-Havâşîalâ Şerhi'l-Mevâkıf Adlı Eserinin Kelamdaki Önemi” (Master's thesis, Çanakkale Onsekiz Mart Üniversitesi, 2014). The brief information will be given forward in the footnote 41 about the second treatise which is discussing the problem of shubhat al-'ammā. It will be published within the framework of a project that is currently underway. See Osman Demir, "Tracing the School of al-Dawānī in Ottoman Lands: Mu'ayyadzāde 'Abd al-Raḥmān's Natural Theology in Comparison with His Master Jalāl al-Dīn al al-Dawānī,” University 


\section{A. The Text: Can we really refer to two different treatises for Mu'ayyadzāda?}

In his Kashf al-ẓunūn, one of the classical bibliographical sources, Kātib Çelebi (d. 1067/1657) mentions two works of Mu'ayyadzāda that coincide with the subject of the treatise being discussed here: the "Risālatun fi-l-juz' alladhì lā yatajazza"'5 and the "Risālatun fi-l-kurat al-mudahraja," respectively. ${ }^{6}$ Kātib Çelebi provided no additional explanation on the first one, but he did provide extra sentences for the second: "There [in this treatise], he has collected strange books, some of which none of his contemporaries ever heard of [i.e., that were unknown to them], let

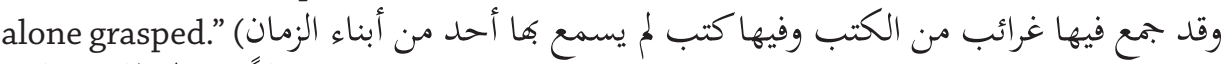
Yet when we examine the text we have published as a critical edition, we detect that the treatise is not as indicated by Kātib Çelebi, and does not contain excerpts from the books that were unknown in his time. In this case, it is probable that Mu'ayyadzāda might have authored another treatise in which he discussed the subject of "rolling sphere."

However, when we inspect the information on Mu'ayyadzāda given by Taşköprīzāde Aḥmad Efendi (d. 968/1561) in his biographical dictionary al-Shaqa’iq al-nu'māniyya, the source of the problem becomes clear. At the end of the chapter he devotes to Mu'ayyadzāda, he gives information about the latter's works and shares some of his comments. The last work that Taşköprīzāde mentions is a treatise entitled Risālatun fi tahqià al-kurat al-mudahraja. After mentioning its name, he wrote on the books collected by Mu'ayyadzāda and the library he created: "He [Mu'ayyadzāda] has collected strange books, some of which none of his contemporaries had ever heard of, let alone grasped. I heard that his library consisted of seven thousand volumes, except for the duplicated ones."7 Therefore, it appears that Kātib Çelebi's information on the second treatise was caused by a mistake in the manuscript he consulted as a source, or by a misunderstanding due to his own negligence.

of Bonn, Alexander von Humboldt Kolleg for Islamicate Intellectual History. The third one is about the indivisible part (al-juz' alladhì lā yatajazza'), which is our topic here. On this occasion, we are much obliged to Judith Pfeiffer for her encouragement and contributions in the formation and execution of that project. For a symposium paper that introduces this specific treatise, see Osman Demir, "Amasyalı Bir Âlimin Atomculuk İncelemeleri: Müeyyedzâde ve Cüz Risalesi," Uluslararası Amasya Âlimleri Sempozyumu Bildiriler Kitabı, ed. Şuayip Özdemir and Ayşegül Gün (Amasya: Amasya Üniversitesi, 2017), 1, 491-500.

7 Taşköprīzāde, al-Shaqā’iq, 179. 
Besides, the sources of the period such as Mahmūd al-Kafawi (d. 990/1582) ${ }^{8}$ and Taşköprizzāde refer to Mu'ayyadzāda as having written "a treatise on the rolling sphere," but do not mention any work by him on "the indivisible part." In one of the manuscripts we have received (i.e., the fifth copy), the treatise was named "Risāla-i Kura-i Mudahraja." As can be understood from the author's expressions, one can conclude that the major text of our subject is a [long] gloss written on the topic of "the indivisible part" in Sharh al-Mawäqif that some scholars refer to as "The indivisible part" and others as "The rolling sphere."

So far, our research has located eight copies of this work. First of all, the copyists must have experienced great difficulty because the topic is a delicate subject that touches many disciplines and because the use of similar expressions / interpretations is very common. This situation causes a lot of errors in manuscripts and greatly reduces the number of copies that can be considered when preparing the text's critical edition. We mention them here in terms of how important they were to preparing the critical edition.

1. Süleymaniye Library, Carullah Efendi Section, MS 1341, 108b-113b. This is a collection of glosses written mostly on Sharh al-Mawāqif. Mu'ayyadzāda's glosses on the subjects of "Juz'un lā yatajazza" and "al-shubhat al-'āmma" were copied in a consecutive manner. According to the colophon of the "al-shubhat al-āmma" treatise, the copying of the treatises was completed at the end of Dhū al-qa'da 901 (i.e., August 1494). Due to the fact that it is both the oldest and contains the fewest errors, this copy is accepted as the most reliable one and is indicated by the letter $\mathrm{P}$.

2. Süleymaniye Library, Fatih Section MS 5414, 31b-38b. The fourth treatise of this collection, which is composed of eight small or large pieces, is the "juz'un lā yatajazza" that we have considered as a source for our criticaledition. The expressions on the flyleaf (wiqāya page), on the manuscript's first page (zahriyya page), and on the treatise's first page (31b) indicate that this manuscript clearly belongs to Mu'ayyadzāda. Even though the date of copying is not clear, it is a faithful / reliable copy. Therefore, we used it and denoted it by the letter $\boldsymbol{Z}$.

3. Escorial Library, Ms. Árabe 236. Three glosses of Mu'ayyadzāda on the Mawāqif are consecutively located between the pages of $69 \mathrm{~b}$ and $100 \mathrm{~b}$. On both the manuscript's opening page (1a) and the page where the relevant glosses begin 
(69a), the relationshipof the treatises to Mu'ayyadzāda was clearly stated. According to the data given on page 69a, the glosses were copied from the author's autograph manuscript and passed thorugh the muqäbala (collation) process. But despite this positive statement, it contains more errors than the [first] copy, which serves as the basis of our critical edition. In addition, the expression "sallamahū Allāh," which appears in the "minhu" records on the margin, suggests that the copy was written while the author was alive. However, no data is given about the date of copying. The section "juz'un lā yatajazza," the subject of our critical edition, is located between pages $85 \mathrm{a}$ and $93 \mathrm{~b}$ in the MS and indicated by the letter $J$.

4. Süleymaniye Library, Şehid Ali Paşa Section, MS 2829, 31a-33b. Since the title "Ajwibat al-'Idhārī" was written at the beginning of the treatise, this work was attributed to Molla 'Idhārī (d. 901/1496) in the catalog records. On the other hand, this work seems to be confused with Molla 'Idhārī's answers to the treatise of al-Sab' al-shidād written by Molla Luṭī (d. 900/1495), which comes immediately after the first. Finally, on a different line, the accurate record / name was added to the beginning of the original Ajwiba. Considering the mistakes in this copy, which has no date of copying, it is understood that it was in the same branch with the copy of Carullah MS 1341. For these reasons, we did not consider it as a source for our critical edition.

5. Süleymaniye Library, Süleymaniye Section, MS 1049, 52a-57a. Although the date of copying (947/1540-41) and the name of copyist (Pīr Aḥmad Rāhī) are certain, we did not consider this copy as a source for our critical edition because of the problematic issues in its text. On the treatise's opening page (52a) is the title "Risāla-i kura-i mudahraja."

6. Köprülü Library, Fazıl Ahmed Paşa Section MS 1596, 169a-177b. The same collection contains the treatise written by Mu'ayyadzāda on the subject "alShubhat al-āmma." This copy is indicated in our critical edition by the letter ك.

7. Beyazıt Manuscript Library, Veliyüddin Efendi Section, MS 3263, 177b-183a. It is stated in the colophon that this treatise belongs to Mu'ayyadzāda and that its copying was completed on Ramadan 4, 941 (March 9, 1535. Because it is an extremely problematic copy, we did not consider it as a source for our critical edition.

8. Bursa İnebey Manuscript Library, Hüseyin Çelebi Section, MS 629. The treatise is located between pages $21 \mathrm{~b}$ and $27 \mathrm{~b}$ of this collection. 


\section{B. Content}

\section{The Problem of Contiguity in Kalām}

According to the mutakallimūn who defend the theory that the body is made of atoms, those pieces that have eternal existence must come together to form a material object and the physical world. Otherwise, the composition of a three-dimensional concrete body and a world made up by these elements from dimensionless, non-extended, and homogenous pieces would be impossible. Thus, an object's existence was first explained by carrying of the parts that were firstly identified by the point but then coincided with it to the accident of combination ( $t a^{\prime} l i f$ ) It was also assumed that this combination formed no integral integrity but that it was, in a discrete manner, in line with the axioms of discontinuity geometry. Thus, the combination of a body that has width, length, and height from the dimensionless part, explained in first place; and then the problem of space and continuity caused by atomic physics, the atom, and environment relationship; and finally the phenomenon of diversity in objects and many issues concerned with the direction, extension, volume, quantity, and quiddity were analyzed and found to be compatible with theological acceptance. ${ }^{9}$

There is no apparent difference between words such as ta'lïf, i'tilāf, tamāss, mumāssa, tarkīb, mujāwara, ijtimā' indimām, and mulāqāt in the early sources. However, when defining the body, it was preferable to use ta'lif and i'tiläf in order to explain the combination of parts. In this respect, they took precaution as regards the possibility of infinite division by defining "combination" as the absence of one part between two other parts, and assumed that a place or a vacuum was occupied by the middle part. If the parts were combined in a way that allowed no gaps between them, then there were cases such as adjacent, adhesion, contiguity, and combination. It is also stated that without the contribution of this accident, the object's separation (tafrīq) would not be in question. ${ }^{10}$ In this context, all of the Atomculuğu, 17-20.

10 For a description of the attribute of combination in the science of kalām, see al-Juwaynī, al-Shämil fi Usūl al-Dīn, ed. 'Alī Sāmi al-Nashshār, Suhayr Muhammad Mukhtār, Fā'iz al-Badr 'Awn (Alexandria: Munsha'āt al-Ma'ārif, 1969); Ibn Mattawayh, al-Tadhkira fî Ahkām al-Jawāhir wa-l-A'rād, ed. Daniel Gimaret (Cairo: Ma'had al-'Ilm al-Faransī, 2009), 1, 289-90; al-Taftāzānî, Sharh al-Maqūṣid (Beirut: 'Ālām al-Kutub, 1998), 3, 10-11; al-İjī, al-Mawāqif, 2, 205-14; Kâdî Abdülcebbâr, Nedensellik Kitabr: Kitâbü't-Tevlîd min Kitâbi'l-Muğnî, tran. Osman Demir (Istanbul: Klasik Yayınları, 2015), 108. For Ibn Sinnā's usage of "combination" and "separation of the body" to refute an atom, see Ibn Sīnā, Kitāb al- 
following issues focused on details: the number of the combinations' attributes that constitute the finite object, the combination's need for a second part or place, the combinations' homogeneous nature and its oppositeness, the combinations' types and conditions, the combination's location in the body, ta'lifs effects on the body's characteristics (especially in terms of its volume and shape), the part's status before the combination, $t a^{\prime} l i f$ s solution to the problem of interpenetration (tadākhul), the casual relationship between adjacent and ta'lif and, more particularly, the troubles caused by the middle part assumed by the conjunction of two parts. ${ }^{11}$

Al-Naẓāām's (d. 231/845) investigations allowed mutakallimūn to review contradictory aspects of their allegations concerning the defenders of an indivisible part in the early period and thus to deelop a more coherent theory. In this respect, the logical and philosophical evidence from the Greek sources was used to prove the part as well as answer the opposing allegations. This situation, first identified in the debate between Abū al-Hudhayl (d. 235/849-50 [?]) and al-Nażām, created important chapters in the works of the muta'äkhirūn period, and the secondary topics discussed during the first period began to be examined in independent treatises. In this context, contiguity, one of the strongest pieces of evidence of the al-jawhar al-fard, was verified by arguments both for and against. In the first period, the concept of tamāss (or mumāssa) was used mostly to express a combination of parts; however, it later became an important proposition of the body's definition,

Shifä', al-Ṭabī'iyyāt I: al-Simâ' al-Ṭabīìn, ed. Said Zāyed (Qum: Menshūrāt Āyatallāh al-Uzmā al-Mar'āshī al-Naj'î, 1409), 185.

11 For the part required for combination and its location, see al-Ash'arī, Maqālāt al-Islâmiyyīn wa-l-Ikhtilāf al-Mușallin, ed. Hellmut Ritter (Wiesbaden: Franz Steiner Verlag, 1963), 302-03, 317; Ibn Mattawayh, al-Tadhkira, 1, 71-74; Ibn Fūrak, Mujarrad Maqālāt al-Sheikh Abu al-Hasan al-Ash'arī, ed. Daniel Gimaret (Beirut: Dār al-Mashriq, 1987), 212-13. For the issue of the middle part between two parts in contact, see Ibn Hazm, al-Fașl fi-l-Milal wa-l-Ahwā' wa-l-Niḥal, ed. 'Abd al-Raḥmān 'Umayra and Muḥammad Ibrāhīm Nuṣayr (Beirut: Dār al-Jīl, 1996/1416), 5, 224-25; al-Nīsābūrī, al-Masā’il fi-l-Khilāf bayna alBașriyyīn wa-l-Baghdādiyyīn, ed. Ma'n Ziyāda and Riḍwān al-Sayyid (Beirut: Ma'had Inmā‘ al-Arabī, 1979), 47-55, 96; Ibn Mattawayh, al-Tadhkira, 1, 72-74; Eşref Altaş, "Fahreddin er-Râzî̀nin el-Cevherü'lFerd Adlı Risalesinin Tahkiki ve Tahlili," Nazariyat İslâm Felsefe ve Bilim Tarihi Araştırmaları Dergisi 2, no. 3 (Ekim 2015): 142-46 (We would like to thank Eşref Altaş for sharing with us a draft Turkish translation of this treatise). For the conflicts between al-Jubbā'îs judgements of combination, see al-Juwaynī, al-Shāmil, 471-78; al-Nîsābūrī, al-Masā'il, 96-100; al-Jurjānî, Sharḥ al-Mawāqif, ed. 'Abd al-Raḥmān 'Umayra (Beirut: Dār al-Jīl, 1417/1997), 2, 215-17. About the types of combinations, see Ibn Mattawayh, al-Tadhkira, 1, 293-97. For the causal relationship among combination, adjacent, and the natural tendency/impetus (i'timād), which are originated deeds, and related discussions, see Kādi Abdülcebbâr, Nedensellik Kitabı, 52-65, 167-73. For the study that examines the debates between the Basrians around the formation of bodies from atoms and the attribute of combination in the center of Ibn Mattawayh, see Dhanani, The Physical Theory, 90-95, 148-60. 
including the problems contained by the idea of interpenetration. ${ }^{12}$ Thus contiguity, which explains the atom's effect on forming the material world, was both the strongest and the most criticized aspect of atomism.

As a matter of fact, the contribution of those elements that have nodimension or boundary of their own, and thus form a dimensional body by contacting them, is an issue that al-Nazzām criticized and found impossible in the first place. ${ }^{13} \mathrm{Ibn}$ Hazm (d. 456/1064), the other important opponent of the atomism during the first period, specified when he was presenting the evidence of junction contained within the claims of those who proved the part, that following two finite and limited parts each other, finally indicates the existence of the intermediary part, which ultimately led to the possibility of infinite division. ${ }^{14}$

The evidence of contiguity was also very effective for the philosophers, who believed that the material world consists of matter and form, both of which allow estimative division, an assertion that could be used against the atomists. Ibn Sinna (d. 428/1037), who found the infinite division of an assumed point in many places to be more appropriate for the correct imagination, criticized those who claimed that a body was formed by the contiguity of finite parts based upon their contention that the middle part prevented contact with the parts on the various sides. ${ }^{15}$ According to him, the contiguity of actual undivided parts requires contact with other parts in the middle, and other middle parts are formed in the assumption. Thus, as a logical consequence of these never-ending contacts, the potential infinite divisions may occur in the estimation. That is, the middle (häjib) of the three parts forming the

For example, Ibn Sīnā focuses on concepts such as succession, contiguity, duplication, inclusion, concatenation, mediation, edge, accompaniment, and singularity while examining the objects. See Ibn

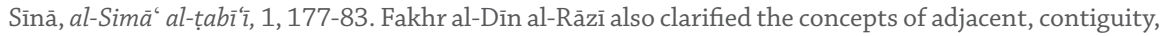
interpenetration, and encounter concerning with the al-jawhar al-fard. See Fakhr al-Dīn al-Rāzī, Sharh 'Uyūn al-Hikma (Tehran: Mu’assasāt al-Ṣādiq, 1415), 2, 101-05.

13 For a review of the debate between al-Nazzām and Abū al-Hudhayl and al-Nażām's criticism of atomism, see Mehmet Bulğen, Klasik İslâm Düşüncesinde Atomculuk Eleştirileri (Istanbul: MÜ İlahiyat Fakültesi Yayınları, 2017), 79ff.

14 Ibn Hazm, al-Fașl, 5, 224-25.

15 Ibn Sīnā, al-Ishārāt wa-l-Tanbīhāt, ed. Sulaymān Dunyā (Egypt: Dār al-Ma'ārif, nd.) 2, 152-57; Ibn Sīnā, Kitāb al-Najāt, ed. Mājid Fakhrī (Beirut: Manshūrāt al-Āfāq al-Jadīda, 1982) 139-40; Ibn Sīnā, 'Uyūn al-Hịma, ed. 'Abd al-Raḥmān al-Badawī (Beirut: Dār al-Qalam 1980), 24-26. In return, the mutakallimūn carried that debate into this medium part and tried to prove that its division was not a logical necessity; see. Ibn Mattawayh, al-Tadhkira, I, 89-90; al-Rāzì, Sharh al-'Uyūn, 2, 102, 105; alRāzī, Al-Mabāhịith al-Mashriqiyya fī 'Ilm al-Ilāhiyyāt wa-l-Ṭabī'iyyāt, ed. M. Mu'tasim-Billāh al-Baghdādī (Beirut: Dār al-Kitāb al-'Arabī, 1990), 2, 19-21; al-Rāzì, al-Mațālib al-'Āliya min 'Ilm al-Ilāhī, ed. Aḥmad Hijāzī al-Sakkā (Beirut: Dār al-Kitāb al-'Arabī), 1987, 4, 53-54; 85-86; 96-97; al-Rāzī, "Cevher-i Ferd," 144-45; al-Jurjānī, Sharh al-Mawāqif, 2, 347-48. 
line that prevents the contiguity of the two sides (tarafayn). In this case, the middle part must make contact with the parts on different edges in order to prevent them from touching each other. Thus, the middle part may be logically - but not actually - divided. Ibn Sinnā found no evidence of the combination used by the atomists to form the object that could serve as an admissible premise; for this reason, he tried to refute them by proving it can be used in the opposite direction. ${ }^{16}$

Although Fakhr al-Dìn al-Rāzī did not accept contiguity as a strong proof for denying atomism, he did take it seriously in his works. ${ }^{17}$ While reviewing in his atomistic research all of the evidence produced for contiguity, he also stood on the evidence of rolling sphere upon which Mu'ayyadzāda centered his argument. According to this, the advocates of jawhar al-fard saw a sphere that contacted a simple object at a single point to transit the surface through successive points as evidence that a line consisted of indivisible points. Al-Rāzì replied by denying the intermediacy of moments to contiguity and their actual existences on the grounds that the point exists either in state of rest or can be apprehended by thinking of the moments. Contiguity at the moment of movement occurs due to the curved line's tangency to the flat surface, not because the contact point in the sphere touches the points in the objects. ${ }^{18}$ He explained that an encounter place (tangent) of a real sphere faced with a flat surface would not be divided by the help of geometrical evidence and responded to the objections. ${ }^{19}$ After the sphere returns to complete the circle on the surface to prove its jawhar, it encounters a point; however, the other point either disappears or there is no other point between the two points forming the contiguity. Essentially, the line is formed by the point at the first time of the encounter, and thus the line consists of a combination of two points, the surface consists of lines, and the object consists of surfaces. Al-Rāzì examined and rejected the contradictions (munāqaza) implied by the denials of the atom and their use to prove infinite division. ${ }^{20}$ in many philosophical works. For example, see Aqkirmānī, Iqlīl al-Tarājim (Istanbul: Dār al-Ṭıāaāt alÂmira, H.1266), 8.

19 Al-Rāzĩ uses Euclid's theorems to prove that the encounter place will not be divided and answers the objections to this evidence. See “Cevherü'l-Ferd," 124-27; al-Mațālib, 4, 47-52; al-Mabāḥith, 2, 34-41.

20 For the mutakallimūn's criticism of the evidence of contiguity, see al-Rāzī, "Cevherü'l-Ferd," 115-16. To practice of mutakallimūn the evidence of contiguity and encounter, see al-Rāzī, "Cevherü'l-Ferd," 14247; al-Rāzì, al-Mațālib, 4, 85-88. 
After al-Rāzī, voluminous works reviewed the matter in a similar systematic manner when studying the rational, logical, and geometrical evidence for al-jawhar al-fard and prime matter (al-hayūlā) Although these books often approached the issue by means of al-Rāzìss methods and proofs, different approaches were exhibited when the contents and compositions were taken into consideration. The mutakallimūn mostly tried to defend atomism; however, due to a certain degree of disagreement they sometimes avoided a definite conviction on atomism. Thus they continued to propose solutions to the subtle issues mentioned during the first period. In this context, the issue of contiguity was at the top of the evidence they were applying to the natural inquiries of the muhaqqiqūn, who followed philosophical and theological methods. The mutakallimün continued to use the evidence of the "rolling sphere" examined by Mu'ayyadzāda in line with the solution of atomist physics, especially in proving the indivisible part. ${ }^{21}$

\section{Cancelling the Perpetuity of Contiguity in Time}

Mu'ayyadzāda begins the treatise with the proof of the rolling sphere (al-kurat almutaharrika) used by al-Ijji to prove the existence of the indivisible part. Accordingly, the invisibility of a point of a real sphere, which is tangent to a flat surface, is an important proof of the undivided part's existence. This is so because if it is happening in one direction, then this point's division will form the surface; if it is in a multiple direction, then it will form the surface. Both possibilities will disqualify the sphere from being a real sphere. In addition, the rolling of the sphere in contact with all of these points proves the existence of undivided parts. ${ }^{22}$ Thus, encountering a sphere that moves both in both a circular and a linear fashion simultaneously with a flat surface that does not accept a division guarantees the two shapes and the relationship between them. Otherwise, the points that are divided forever will eliminate the boundary of geometric shapes and objects, meaning that you will not be able to assume a real sphere or surface.

21 For the proofs of the part (juz') including the evidence of contiguity and the rolling sphere, see Shams al-Dīn al-Samarqandī, al-Ṣaḥāif al-Ilāhiyya, ed. Aḥmad 'Abd al-Raḥmān Sharīf (Kuwait: Maktabat alFalāh, 1985), 262-67; al-Āmidī, Abkār al-Afkār, ed. Aḥmad Muhammad Mahdī (Cairo: Dār al-Kutub, 2004), 3, 55-64; el-Urmawî, Sirāj al-Dīn. "Mațāli al-Anwār," ed. Hasan Akkanat. "Kadı Siraceddin elÜrmevi ve Metaliu'l-Envar (tahkik, çeviri, inceleme)," Hasan Akkanat. Doctoral Dissertation, Ankara Üniversitesi, 2006, 1, 230-36. Al-Taftāzānī, Sharḥ al-Maqāṣid, 3, 32. Although Shams al-Dīn alSamarqandi mentions the pieces of evidences such as the point and movement used to prove the atom, he does not include any other evidence of contiguity, including the rolling sphere. See Mațāli al-Anzāar (Istanbul: Shirkat-i 'Ilmiyya, 1305/1887), 242-48.

For the relevant paragraph, see al-İjī, al-Mawāqif, 2, 331-32. See edited text in this article, pp.162 
Mu'ayyadzāda subsequently records that by narrating from the relevant chapter's commentary, Ibn Sinā responded by assuming that a sphere that is tangent in one point to the flat surface will come into contact at another point with a divided time and a divided movement. ${ }^{23}$ Thus, he agrees to the imagination of a piece (point) in the estimation and its infinite division and states that the sphere and the surface are combined with the line, not with the adjacent points, in accordance with the sensory signal. ${ }^{24} \mathrm{He}$ also presents the objection that, in such a case, an absurd result will emerge, such as a sphere touching the surface at two points and at the same time, saying that the first point of contiguity will be completely eliminated when the sphere touches the second point. Therefore, the sphere contacts the surface with a line in the condition of movement and with a single point in the state of rest. However, the actual time in which this contact with the point is realized is only in the estimation, because it is impossible to think of an actual time without thinking of an actual instant that has no actual existence. Thus, Ibn Sīnā rejects the mutakallimūn's claim that the instant in which a sphere meets with a surface is a point, for, according to him, you do not need the transition to move from one point to an adjacent point, and from one instant to another adjacent instant, for that would eliminate the need for the sphere or a surface, apart from encountering points, and the line from these points does not even have to occur. ${ }^{25}$

Thus Mu'ayyadzāda tries to reveal the problem primarily by specifying two current approaches to contiguity. He rejects the second view, the idea that the touch point does not change with the change of the time (baqā' al-tamāss), and provides eight geometric proofs for its cancellation. ${ }^{26}$

23 Mu'ayyadzāda translates this reply from al-Jurjānī. See Sharḥ al-Mawāqif, 2, 340-41.

24 See Ibn Sīnā, al-Simā'al-Ṭabììi, I, 201-02; Ibn Sīnā, al-Ishārāt, 166-67; Ibn Sīnā, al-Najāt, 147.

25 Ibn Sīnā, al-Simā'al-Tabìì î, 1, 303-04. See edited text in this article, pp.162

26 The ijāzatnāma which was given by al-Dawānī, shows that Mu'ayyadzāda received a serious mathematics education. See Judith Pfeiffer, “Teaching the Learned: Jalāl al-Dīn el-Dawwāni’s Ijāza to Mu'ayyadzāda Abd al-Rahmān Efendi and the Circulation of Knowledge between Fars and the Ottoman Empire at the Turn of the Sixteenth Century," The Heritage of Arabo-Islamic Learning: Studies Presented to Wadad Kadi, ed. Maurice A. Pomerantz and Aram Shanin (Leiden and Boston: Brill, 2015 [2016]), 309-11. His scribe Nasīr al-Dīn al-Ṭusī's compilation (taḥrîr) of Euclid by making some notes on the edge of the pages also shows his level and concern for that topic. For a related copy, see Nasīr al-Dīn al-Ṭūsì, Taḥrīr Uqlìdis fi-l-Ușūl al-Handasa wa-l-Hisāab, Beyazıd Devlet, Veliyyüddin Efendi 2304. 
The first argument (figs. 2 and 3) is taken from Theodosius ${ }^{27}$ (160-100 вСЕ), Kitāb al-Ukar (Sphaerica). ${ }^{28}$ Accordingly, when we draw perpendicular ('amūd) to form the diameter of the sphere from its tangent point to the surface, in the time of the continuity of the assumed contiguity, this diameter must either move or stop. In the first case, the movement of the sphere requires that this pole be part of a second pole that will occur as a result of its rolling (see Fig. 3). The fact that a right angle is part of another right angle is impossible in terms of the part-whole relationship. In the second probability the diameter stops, which means that the sphere also stops and a contradiction (khulf [reductio ad absurdum]) occurs, because in the first case the sphere is assumed to be rounding, and that possibility could also be refuted.

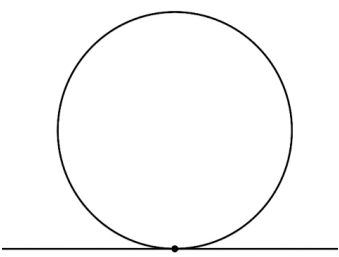

Figure 1. The sphere touches the surface at only one point

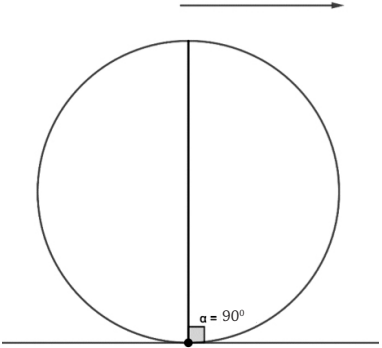

Figure 2. The first position of the sphere: The diameter is perpendicular to the surface at the tangent point

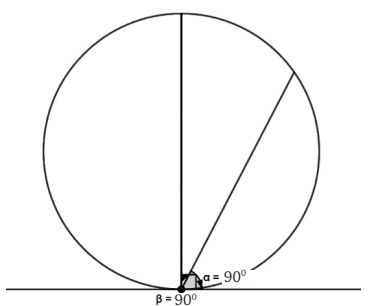

Figure 3. The second position: With the motion of the sphere the first right angle becomes the part of newly formed right angle.

The second argument benefits from the work of Autolykos (360-290 вСЕ), namely, al-Kurat al-Mutaharrika. ${ }^{29}$ Hence, when the sphere rounded a tour with a constant velocity (mu'tadil), each point on its surface draws parallel and proportional arcs to each other at the same time (Fig. 4). If the contact continues at some point, as is claimed, the rate of an arch in which the tour of the sphere

Nasīr al-Dīn al-Ṭūsī, after revealing the project of the tahrīrāt, prepared the texts entitled tahrīr, which replaced the original translations by preserving the classical names of the books and authors. Therefore, the references of Mu'ayyadzāda in the first and second arguments in the classical sources appear in texts known al-Ṭūsīs al-Mutawassițāt. Due to the fact that it has a possesion record, the copy of Tahrirr al-Mutawassițāt that we have and was used by Mu'ayyadzāda is now located in the Süleymaniye Library Ayasofya Collection, MS 2760.

28 A related theorem is the fourth figure of Tahrìr al-Ukar's first article. See Nasīr al-Dīn al-Ṭūsī, "Tahrīr al-Ukar li-Thāwudhūsyus," in Majmū' al-Rasā’il (Hyderabad: Mațbāat Dā'irat al-Ma'ārif al-'Uthmāniyya, 1358), 4.

29 A related theorem is the second figure of Tahrīr al-Kurat al-Mutaharrika. See Nasīr al-Dīn al-Ṭūsī, “Taḥrīr al-Kurat al-Mutaharrika li-Awțūlūqus," in Majmū' al-Rasā'il (Hyderabad: Mațbā'at Dā'irat alMa'ārif al-'Uthmāniyya, 1358), 3. 
transits in that point, for instance in an hour, should be smaller than the rate at which another point transits at the same time. So, the sphere in the tangent point is not removed from the touch position, but continues to revolve at other points as a requirement for the contiguity's continuation. This continuation of each tangent point by stopping for a while- the sphere will necessarily come into contact with the surface at one point at a time - results in the break off of the sphere, which is also clearly invalid.

The third evidence suggests that if the contact's continuity is accepted in time, then the touchpoint will not be separated from its position for as long as the contact continues. Yes, there is actually a point that does not change its position in a rotating sphere. But this particular point can only be the polar points of a sphere that revolves around its own axis. However, our assumption is that the moving sphere is rolling, as opposed to rotating, around its own axis. Therefore, if the assumption is accepted, a contradiction emerges: The sphere both rolls and does not roll (i.e., it revolves) around its own axis at the same time.

In the fourth argument, a large circle is drawn on a sphere passing through its two touchpoints (A and B), and it is assumed that the sphere moves on it and on the straight line on the surface (Fig. 4). Continuing the contiguity at the first point (A) continuously up to the second point (B) will reveal the following possibilities: (i) If the second contact occurs at a point other than the arc between the two points, the sphere will contact with the surface at more than one point; (ii) If the second contact occurs on the aforementioned arc, either (i.i) this arc between two points coincided with the straight line on the surface - so that it touches the surface at every point - which was assumed to be tangent only at one point; (i. ii) if the arc and the straight line do not overlap with each other, it is necessary to acknowledge that the sphere is either (i.ii.iii) a leap (țafra) movement in order to form the second contact, or (i.ii) that the sphere does not roll over this circle. All of these assumptions contradict the first assumption.

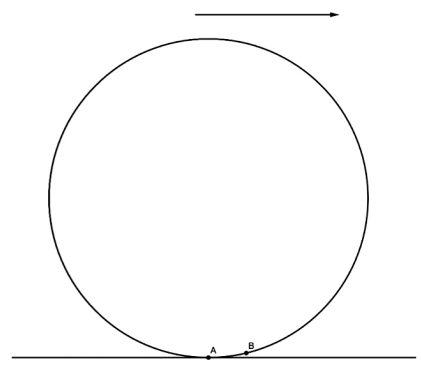

Figure 4. Point $(\mathrm{A})$ is currently in contact with the surface, and point (B) will come into contact with the rounding of the sphere 
The fifth evidence indicates that each point between the two assumed touchpoints on the arc mentioned in the previous argument (Fig. 4) is closer to the surface than the second contact point. When we handle this set of points, a point that is closer to the first tangent point is closer to the surface than a point that is farther away from it. In this case, if the closer point does not reach the surface, then the farther point also does not reach the surface. As a result, since there is no point in the arc that occurs between the two points (A and B) that does not come into contact with the surface, it is impossible for the contiguity to happen with points that do not follow each other and the continuity of the contact at some point. In other words, the tangent points must have changed as time passed, and these points must be points that follow each other.

The sixth argument is based on the assumption that two touchpoints formed an arc and a hypothesis of a circle (Fig. 4), as in the previous two arguments, and the postulate that the touchpoints were not removed from their positions. If we assume that the touchpoints are not separated from their positions, then they must complete the exact return of the points between them before they can complete a full rotation. But as the fifth argument revealed, it is impossible to complete distant points before close points can complete the movement. Hence, a contradiction emerges here.

The seventh argument is based on the smallest angle evidence included in Euclid's (third century BCE) Elements. As proved in the fifteen shape/theorem of the three articles of the Elements, the angle formed between a circle and a straight line touching it is is the smallest possible narrow-angle. ${ }^{30}$ One potential result of this theory is that smallest narrow-angle formed between the sphere's perimeter and the line on the surface does not accept a distance that will occur in the aperture. The contact point's continuity, along with the sphere's movement, requires a distance from the aperture of that angle and hence a smaller new angle. This also reveals a contradiction.

In the eighth argument, the contact with the first point where the sphere is tangent to the surface continues until contact is made with the second point. If it is accepted that the moment is eliminated, then three alternatives, all of which are invalid, appear: (i) If there is a single point between the first contact point and the surface, then the three points must come in succession, including the surface, the sphere, and the point between them. (ii) If there is more than one point between 
the two touchpoints, then the sphere must transit a certain amount of distance. This is impossible because the distance, time, and movement should be proportional to each other. (iii) The absence of distance between the tangent points means that these two points are coincident points, which requires that the contact has not yet been interrupted at the first point. The assumption is that when contact with the second point occurs, it is assumed that the first point is eliminated. This is a contradiction.

Mu'ayyadzāda invalidates with these arguments by claiming that it is possible to assume a cross-section in which a rolling sphere has been touched at this time. Accordingly, no crossing section is thought to be constant at the time of movement between the points that are imagined to be touched by a sphere on the surface. It is a factual reality that the sphere moves on a flat surface by touching points that are lined up to follow each other and appear repeatedly after they disappear, one after another. Otherwise, it becomes difficult to defend contrary possibilities because they will cause many logical contradictions, as explained above.

\section{The Well-Known Doubt: The Movement of the Sphere on the Surface}

After canceling the idea of a perpetual of the contiguity in time in a philosophical sense, Mu'ayyadzāda continues the treatise with the subject of the well-known doubt (al-shubha al-mashhüra), which is the main reason why he wrote this text. This issue, which responds to the question of how a sphere that moves on a flat surface passes a certain distance, is important because it distinguishes the theological and philosophical perspectives on nature. The philosophers argue that the sphere reaches a certain distance by passing the points that are assumpted to be infinite in the mind and the constant time between them, whereas the mutakallimūn claim that each point where the sphere touches the surface also creates the ends of distance and that the sphere reaches a limit by contacting these points (i.e., moments and ends). Both theories discussed the concerned issues related to theoretical physics, such as movement, time, distance, and space around this core problem, in the context of their metaphysical principles and opinions about the universe. ${ }^{31}$

Mu'ayyadzāda briefly summarizes this well-known doubt/objection.

31 It's been long discussed whether is the touch of the sphere to the flat by point or line and the connection of this incident with the theories of time and movement. See Ibn Sīnā, al-Simä'al-Ṭabīì , 1, 201; el-Rāzī, "el-Cevherü'l-ferd," 127. Also see al-Rāzì, al-Mațālì, 6, 34; al-Āmidī, Abkār al-Afkār, 3, 61-64; Akkanat, "Kadı Siraceddin el-Ürmevi," 234-236. 
The sphere that moves on a flat surface and crosses it from one end to the other, and every assumed point that it contacts between the beginning and the end, also creates a boundary of the sphere's distance. As long as this sphere continues to move, it cannot remain at the border for more than a moment. Since the form of the movement is mediating between the beginning and the final points, there is neither a "before" nor "after" for the moments/limits that the mover travels through. ${ }^{32}$

This objection responds to the question of how the movement, which is a continuous state, crosses the parts that form the specific distance (i.e., instant, border, and end) and is considered finite and limited in the external world. It also discusses the relationship of continuity and discontinuity around the spatial movement. ${ }^{33}$

In order to grasp this issue, Mu'yyadzāda says that you first need to know the types of occurrences (hușūl). According to this, the falāsifa divided husṣūl into three parts: gradual, non-gradual/momentary, and temporal. There is a compound identity (huwiyya) for gradual ḥușūl like a movement, whereas momentary huușūl occurs only in a moment or in a moment with time. Temporal husụul, which is the vehicle between the two, has no abilty to overlap with time and distance. This means the movement's existence not only at the time or at the end of the distance, but at all assumpted times. ${ }^{34}$ Accordingly, the arrival (wușūl) of the sphere to a limit is temporal in the sense of momentary hușūl, or should be either gradual or momentary, according to the aforementioned classification. Since gradual husșūl requires the the limits of the distances be separated, and momentary hușūl whether at the moment or in time or only in time - is contradictory, both are false. ${ }^{35}$

33 The existence quality of the rest between the two linear lines subjected in the risāla, and also a relation of motion as a flowing state to the ends/boundaries of the distance it passed, has been discussed in different headings in the theological and philosophical works. After mentioning the famous evidence that philosophers adopted and used to prove the state of rest between the two movements, al-Tūsi speaks about Ibn Sīnā's and al-Rāzì's criticism of it and then proposes a solution through the types of occurrence (ḥuṣūl). See Nasīr al-Dīn al-Ṭūsī, Sharḥ al-Ishārāt wa-l-Tanbīhāt (Egypt: Dār al-Ma'ārif, nd.) 3, 154-59. Also see al-Jurjānī, Sharḥ al-Mawāqif, 2, 228. Quṭb al-Dīn al-Rāzì also discusses the same topic in detail. See Quṭb al-Dîn al-Rhāzî, al-Muhākamāt, ed. Karīm Faizā (Qum: Matbū'āt-i Dīnī, 1383/2004), 3, 200-09. If the topic of risāla is taken into consideration, Mu'ayyadzāda expresses an objection that the mutakallimūn directed to this famous evidence. For a detached risāla discussing this issue according to the example of rolling sphere, see Sinān Pasha, Jawāb Sinān Pasha 'an 'I'tirāẹ alQasțallānī fỉ Bahth al-Juz' Alladhī lā Yatajazza', Süleymaniye Library, Hasan Hüsnü Paşa 600, 92a.

According to Mu'ayyadzāda, al-Jurjānī called "momentary (daf ì $)$ hușūl" reaching sphere to one of the boundaries of distance, but al-Ṭūsì devoted momentary ḥuṣūl in the first part and classified temporal ḥuṣūl as "realized at this time and at the end of the time" and "realized only in time without the end of the time." For the momentary and gradually hușūl in al-Jurjānī, see al-Jurjānī, Sharh al-Mawāqif, 2, 226-28; For the types of husūūl in al-Ṭūsī, see Sharḥ al-Ishārāt, 3, 160-61. For the types of ḥușūl, see Quțb al-Dīn al-Rāzī, al-Muhākamāt, 3, 20-211. 
Mu'ayyadzāda needs to make an additional statement to clarify this view. Accordingly, it may be thought that the movement occurred either during the time of rest or the time of movement as a rational possibility. The first case contradicts the assumption; however, its occurrence during the time of rest reveals three options: This movement can occur (i) either to a boundary (end), (ii) or in a boundary (at a moment), (iii), or from a boundary (from beginning). If the movement is always toward the end, then the moving object will never reach that border, which is contrary to the assumption. If the movement is on a boundary, then it requires a division of the moment towards its extension. It is also incorrect to claim that the movement has a starting boundary, because the quality of intermediacy prevents it from getting together with the attribute of location (kawn) ${ }^{36}$ at this border. In this case, as gradual huușūl requires the division of the boundary and momentary husșūl requires the succession of the moment, it will be more accurate to explain contiguity according to temporal hussūl. ${ }^{37}$ Since movement is the sum of the occurrences of the moments that arrive (wasșil) constantly to some place and perishes ( $z \bar{a} \hat{i} l)$ from there, namely, they are absent and existent in relation with the contact, the sphere's arrival at some point through movement is in time and its cessation is in the moment. Thus, time is only perceived by continuity, and moment by the interruption of movement (i.e., discontinuity is also stated).

According to Mu'ayyadzāda, if it is taken into consideration that the points crossed by the rolling sphere between the movement's beginning and end also constitute the boundaries of the distance transmitted, then the contiguity's existence is the sphere's arrival (wuṣūl) to that border, and its lack is the destruction (zawāl) of its existence on that border by moving toward another border. Thus, movement makes a temporal contribution by prioritizing the ends, moments, and points without

probabilities: (i) At this time, if nothing else can move on this border, the moving object will stop here, contrary to the assumption. (ii) When movement is on another boundary, the parts of the movement and its boundaries are combined in the external world.

36 Movement, which was an intermediary between the beginning and the end, is the sum of the momentary occurrence in this sense. Because the atomists say that movement is made up of consecutive nonbreaking occurrences, movement consists of a succession of undivided assumed location (hayyiz) and the sum of the moments. For example, see al-Rāzì, al-Mabāhith, 1, 671. In this direction, the attribute of location (kawn) is described as the sudden emergence of something out of nothing (daf'atan wāhida) not gradually. See Al-Āmidī, al-Mubīn fì Sharḥ al-Ma'ānī al-Alfāz al-Hukamā' wa-l-Mutakallimīn, ed. Ḥasan Mahsūd al-Shāfī (Cairo: Maktabat al-Wahba, 1413/1993), 100.

37 Mu'ayyadzāda declares there is no need to argue about these concepts because philosophers also defined momentary hụșūl, which is a cessation of arrival occurrence on a border of the distance, as a temporal ḥuṣül. See edited text pp. 166 
conjoining any kawn at the boundary of the distance. This happens in time, not during the uppermost moment of the assumed occurrence. At this time and point, to assume the part and the moment, the movement and the arrival that exists at the same point must be eliminated in such a way that the part will combine with another moment at another boundary. Every point that comes together with the contiguity means here also the lack of contact at the first point, and thus the sphere transits between two points by touching the moments in time. Since the first touch, which requires distance and time have certain boundaries in time of motion of the sphere is not continuous, it is also explained that contact is in conjunction with temporal movement and does not need to be continuous in the time of gradual motion. ${ }^{38}$

Mu'ayyadzāda also states that there is no need to claim the existence of a definite distance ( $b u^{\prime} d$ ) between the points and the sphere's surface apart from the touch point, as philosophers did. Previously, Ibn Sinnā's view that the first contact remains until the second touch (baqā' al-tamāss) was invalidated by several geometrical proofs. The assumed time is also part of the time when the contact is destroyed, as it is limited by the instantaneous occurrence of both touches. Therefore, being the touch in that imaginary point ensures that the first contact does not continue and disappear at the same time. According to him, this explanation also ends the confusion about movement in terms of intermediation as well as the subject of the distance at a border. ${ }^{39}$

In fact, there is no movement at the beginning and at the boundaries of the distance, for if there were, it would be possible to reach this limit without moving in the first place. Since movement is a mediator between the beginning and the end, in fact, what is meant by movement is arrival and departure. But because movement is identified by time and not the moment, the line comes to mind once more. The occurrence of movement is not at the end of the distance but at the time of departure, for there is no determined moment for its occurrence in the time of movement. For this reason, the infinite number of boundaries and ends

39 Mu'ayyadzāda attributes that confusion to "some virtuous persons (fädịil)." In fact, many scholars dealt with the same issue. See al-Rāzī, al-Mabāhiith, 1, 674-75; al-Rāzī, al-Mațālỉb, 6, 32-34; al-Jurjānī, Sharḥ al-Mawāqif, II, 226-28. Abū al-Barakāt al-Baghdādī, Kitāb al-Mu'tabar (Hyderabad: Dā'irat alMa'ārif al-'Othmāniyya, 1357), 2, 30-34. Dāwūd al-Qayșarī also records that Ibn Sīnā and al-Ṭūsī were hesitant about continuity between the renewed momentary motion and the flowing temporal one. See al-Qayșarī, Nihāyat al-Bayān fì Dirāyat al-Zamān, ed. Mehmet Bayrakdar (Kayseri: Kayseri Belediyesi Yayınları, 1997), 168. Al-Qayșarī indicates that there is not a real, but rather an estimative, continuity between the two movements. See al-Qayșarī, Nihāyat al-Bayān, 49. See also the theory of time in al-Qayșarī: Osman Demir, "Dâvûd el-Kayserî̀nin Tasavvuf Metafiziğinde Zaman," Osmanlida İlm-i Tasavvuf, ed. Ercan Alkan and Osman Sacid Arı (Istanbul: İSAR Yayınları, 2018), 431-48. 
can be considered rationally, between each boundary and its endings, which are assumed in time. Movement takes place across all of these boundaries by means of conjoining time and admitting infinite division. Also, there is no exact limit for the distance that overlaps with time and movement and admits division.

After canceling the endurance of the contiguity in time and explaining his opinion on the relationship of movement and rest by agreeing to temporal occurrence, Mu'ayyadzāda comes to the main topic (mațlūb) and begins to explain how the sphere rolls on the flat surface. He eliminates three options that have no effect on this subject before specifying his preference, as follows:

i. Contiguity does not occur via the succession and regularity of the points that renew and expire constantly one after another, because accepting this requires successive points and moments to follow each other. Even one of them is enough to prove the part's external presence.

ii. Contiguity does not occur by the perpetuity of the essence of the flowing point, for its identity continues from the beginning of the roll to the end. The point is not moving by its essence, and this impossibility is understood from the contact point on the surface more than the sphere. ${ }^{40}$

iii. Contiguity does not occur by two stable lines, one of which is linear and the other of which is circular, and their parts are together. Because there is no line in the sphere or on the surface, contiguity cannot make them appear. The thing that provides contiguity is the same as before and after the contact. And in any case, there is an actual line in the middle. ${ }^{41}$

After eliminating these possibilities, Mu'ayyadzāda concludes that the sphere comes into contact with the surface with to lines and the part's of this line doesn't encounter with each other at the same time (ghayr al-qārr). In other words, if it causes movement then there is no prior or post contact. If the rolling of the sphere is a thing that has no actual parts, its pieces do not come together, continuous and single in the nafs al-amr (fact of matter). The thing that provides contact is similar: A line whose parts do not meet each other. ${ }^{42}$

40 Here, Mu'ayyadzāda is referring to the al-shubhāt al-'ämma debates and the treatise written on this topic. Several copies of this treatise address the question of whether something that moves does so across a certain distance constantly through a single space or multiple spaces? For example, see Mu'ayyadzāda, Fī al-Shubhat al-'Āmma, Köprülü 1596, 142-147. This topic has also been discussed by al-Jurjānī and has its own literature. For the relevant chapter, see al-Jurjānī, Sharh al-Mawāqif, 2, 244-45.

41 See edited text pp. 169-170

42 See edited text pp. 170 
Thus, Mu'ayyadzāda solved the problem of admitting actual infinite parts that presumably this contiguity can lead it by stressing that contiguity caused by a line also proved the point's external existence by applying the categeory of nafs al-amr, ${ }^{43}$ which was used in the ontology of mathematical proof. He states that this claim is not a denial of the part, as was thought. However, Ibn Sinnā, who explained the spheres contiguity with an extended point (line), did this in order to reject the idea of the part. In accordance with his acceptance that both movement and time are continuous and have no starting parts, he argued that there is no first part for the contiguity, which is moving and in a continuous state. He contends that a sphere in a state of motion contacts the surface with a real line, but that touching it with a point that has no actual body only takes place in the imagination (wahm) ${ }^{44}$

In return, Mu'ayyadzāda finds it sufficient that the realization of momentary touch, whether or not this instant exists in the external world, in nafs al-amr to prove the point, and like this the realization in the time of movement to prove the line. For him, estimating time and movement is not going to damage this idea. In addition, the ambiguity (ishkāl) of the infinity of an actual-existing point in the rational assumption is out of the question for each line that has assume infinite points on it. Because wahm cannot comprehend infinite situations, the intellect ('aql) comprehends the infinite points between these two lines in a universal and encompassing way. This assumption does not mean that they come out of potentiality and into actuality. For this reason, since the contact at the moment is the reason for the external point, based on the intellectual assumption that the moments can be infinite, the point in the external existence may be infinite. Thus, the contiguity that was imagined as finite in external and infinite in wahm can be explained by means of the category of nafs al-amr. ${ }^{45}$

43 The concept of nafs al-amr seems to have been invented during the process that started with Sayyid Sharif al-Jurjānī in the fifteenth to explain that mathematical models can give true knowledge about reality even though they were assumed to be estimative and to satisfy the need of guaranteeing the existence of mathematical entities via independent ontological-epistemological principles. Fazloğlu, İhsan, "Between Reality and Mentality: Fifteenth Century Mathematics and Natural Philosophy Reconsidered”, Nazariyat Journal for the History of Islamic Philosophy and Sciences 1, no. 1 (November 2014): 1-39.

44 Mu'ayyadzāda finds two disabilities in Ibn Sīnā’s solution of contiguity with the line, which al-Rāzī and al-Jurjānī had pointed out earlier. The first one is that this kind of discontinuous situation is not reasonable, otherwise the movement (i.e., time and transition) needs to be reasonable; however, Ibn Sinā refuted this. Second, as the sphere touches the line during the movement, it also touches every instant assumed in that time. This leads to assume the touch is not with the line, but with the instant. See edited text pp. 171 
Mu'ayyadzāda draws attention to the fact that the main debate is the point's external existence. ${ }^{46}$ While the philosophers agreed that the present point was in the assumption, the mutakallimūn, accordng to their view on the material world to an existing point in the external, wanted to avoid an impossible situation, such as the touch of two lines with a thing that did not exist. Thus, all of them took care to prove the point's ontological existence, which is the focus of the theory of al-jawhar al-fard. Mu'ayyadzāda indicates that the current and most appropriate situation for contiguincy is that the essences of the objects are divided in directions (line and surface). Thus, the reality of the point is proved by congruity to nafs al-amr, the reality of the line is proved by movement and touch, and the contiguity that depends on the two points' existence is also revealed with the line.

Mu'ayyadzāda records that contiguity, which is a constant thing in nafs al-amr, is more appropriate with the momentary occurrence being in the line and does not require an interpenetration (tadākhul). Accordingly the surface, which is an object, attaches the whole body (i.e., not just all or some parts of it), and only spreading (sarayān) in two directions does not require the object and the surface to be divided into directions. He also assumes that something can be contact another just because it is just an object, not because of the parts or some specific part of it. It is also the contiguity of surfaces with lines and the contiguity of lines with points. And, in fact, it needs an argument to prove otherwise. The mind's determination of some of the body's aspects in a sensory signal does not prevent contiguity to attach to the body, because an object spreads in some directions in the sensory signal like the ends. ${ }^{47}$

According to Muayyadzāda, one cannot deny (man) the opinion that the permanence of the surface will require endless surfaces or that the surfaces must end on a substantial surface (jawharī) that essentially exists. Yet, what the surface is attached to (ma'rū that it will eventually have to assume a part that is divided here, that it ultimately ends on the surface divided into two directions. This surface will either last forever (yatasalsal) or end on a surface that exists with the latest substantial surface. It is not possible to imagine similar things on the line and the point. As a vehicle of contiguity, it is also wrong to refer to a body, a part of it, or an entity that exists 
in the external world with a body. The vehicle of contiguity assumes that the body has a surface. If there is no surface, contiguity cannot be attached to the body in any way. Like this, two lines come into contact with a point and two surfaces with a line. In that case, it is not difficult to comprehend the body as characterized in the nafs al-amr with conceptual entities or our thinking of some situations in the body in a way that overlapped the nafs al-amr, to ensure that the current conditions are attached to the body. ${ }^{48}$ Then, contiguity is not an external entity but rather a peculiar relation of positional beings. If this were not the case, then all of these contradictory things could not be attached to the objects at the same time.

Therefore, it is wrong to say that the reason for the contiguity should be outside; if this is expressed, it is also necessary to say that the reason for the contraposition (muhāadhāt) must also be outside. It is assumed that the alignment of two things is realized in the ends (ațräf), such as contiguity, but not like this. According to Mu'ayyadzāda, scholars such as Ibn Sīnā, Quṭb al-Dīn al-Rāzī (d. 766/1365) and al-Jurjānī (d. 816/1413), expressed the same opinion with different phrases and implied that the meaning of the actuality of the thing that provides the contiguity is the entification (ta'ayyun) and distinction (tamayyuz) of reason to that touch. For instance, al-Jurjānī stressed that there is necessarily one direction condition in a body whose extension ends in one-direction, and also there is necessarily one direction condition in a surface whose extension ends in one-direction. ${ }^{49}$ Quțb al-Din stated that the differentiation of the attributes does not require external divisions in the body and that the meaning of the actuality is more general than the existence of external beings. In addition, Quțb al-Dīn strengthens his claim by citing the view of Fakhr al-Dīn al-Rāzì: "The contiguity of the celestial spheres of every star with the celestial sphere of Atlas occurs at a certain point and assumed boundaries, and that this point is not external." ${ }^{50} \mathrm{Ibn}$ Sinna argued that the limits in compound bodies are potential, which is, in fact, the case of contact. ${ }^{51}$ When these

Mu'ayyadzāda gives following examples to prove the assumption of something that is permanent in nafs al-amr in the external; i) the attachment of light to Earth for being in the face of bright bodies and ii) connection of different colors and lights to the adjacent body because of our imagination of them on objects according to true estimation.

49 See al-Jurjānī, Hāāshiya 'alā Sharḥ al-Tajrīd, Hekimoğlu Ali Paşa 833, 220.

50 See Quțb al-Dīn al-Rāzī, al-Muḥākamāt, 3, 199. In the chapter where Quțb al-Din al-Rāzī is quoted, Fakhr al-Dīn al-Rāzì confutes Ibn Sinnā's argument that there must be a rest on the air between the rising and descending movements of the stone which is used as astronomical evidence to prove the succession of the instants. Accordingly, the Zuhal sphere touches the sphere of fixed stars with a single point that occurs at indivisible instant, because the presence of the time of rest between these two moments interrupts the spheres' movement. See al-Rāzī, al-Mațālib, VI, 44-45. 
people said the contact point actually exists, they meant its intellectual existence and its effectiveness at the moment of estimation. ${ }^{52}$

After these footsteps, according to Mu'ayyadzāda, contact occurs in reality when the sphere's surface makes contact with the flat surface. Therefore, two points are appointed on the sphere and on the smooth surface (ta'ayyun). As the sphere rolls over the surface, it continues to touch these two surfaces. Due to this movement, a smooth circular line in the sphere as well as a straight line on the smooth surface become appointed and distinguished. At any given moment assumed in that time, two points appointed from this line, because it is not possible to imagine two instants without time between them or two points without a line between them. The status of the sphere and the surface is like that before the contact. As time and movement are continuous, we think of the two lines (i.e., the surface) and not the successive points at the moment of rolling. ${ }^{53}$

Mu'ayyadzāda believes that this answer is appropriate for Ibn Sīnā, who claimed that the sphere had come into contact with the surface on line at the time of movement. However, it is necessary to think that this line is in the estimation and not in the external, because what provide contiguity ( $m \bar{a}$ bihì al-tamāss) are the ends, and contact is unthinkable without considering them. ${ }^{54}$ Thus, it is understood that Ibn Sinā's view about the actual time, which the contiguity realized by the point, is only in the estimation. And therefore the context of the word (siyāq) requires that the contiguity must be with the line in the nafs al-amr and with the point in the estimation. But a serious study also requires the contact of the two surfaces at the time to be like the contiguity in the instant. However, the fact of contiguity's occurrence with two lines at time will require the line to be at this specific time. But this is absurd. In this case, he states that three possibilities arise, as follows:

i) Momentary contiguity is completely rejected both in reality and in estimation. ii) The occurrence of contiguity in two points on a surface is canceled on the grounds that it requires the realization of infinite points. iii) The occurrence of contiguity with two lines has no reality in the instant and therefore is accepted invalid on account of the fact that this necessitates contact with the non-existent. iv) It is said that contiguity will be realized in two surfaces. With this final statement, the desired demand (mațlüb) is proven and there is no need to prove the two lines for contact in time.

54 According to Mu'ayyadzāda, the word " $b \bar{a}$ " in the phrase "mā bihī al-tamāss" is for causality, not for the connection (șila). Contiguity also attributes to its reason through the expansion of meaning (tawassu) as though it is used the phrase "mā bihì al-muhädhät" about the assumed ends. 


\section{Conclusion}

In this treatise, Mu'ayyadzāda sought to solve the evidence of contiguity that was commonly used in the direction of proof and refutation of the indivisible part and the well-known problems that arose and have been discussed for a long time, such as the relation of movement to space, the time-instant relationship, and accessing the rest between two linear movements by taking into account the current claims and objections. In this respect, he first canceled the Avicennian idea of the perpetuity of contiguity between two points by using geometrical proofs. Subsequently, he adopted temporal occurrence between a momentary occurrence taken by the mutakallimün and a gradual occurrence taken by the faläsifa in terms of time and movement. In this regard, after reviewing the current opinions, he concluded that the moving sphere has come into contact with a discontinuous line to the surface between the opinions that claim that the contact is a point and a continuous line and explained the problems that it has caused. As far as we can identify, his reference to the category of nafs al-amr to clarify contiguity can be seen as a new model of explaining the solution of the "well-known doubt".

In the part where he canceled the perpetuity of contiguity, Mu'ayyadzāda used a strong reference frame by attributing to ancient authors such as Theodosius, Autholycus, and Euclides and explaining the form of contiguity accourding to the major names of theoretical thought such as Ibn Sīnā, Fakhr al-Dīn al-Rāzī, al-İjī, alJurjānī, Quṭb al-Dīn al-Rāzī, and Nașīr al-Dīn al-Ṭūsī. While presenting his claims in the logic of the debate (al-man'wa-l-nakd), he interpreted the ideas confirming his basic thesis either directly or in the direction of his allegations. As it focused on the theoretical and subtle problems reflected in the natural field, it is necessary to seriously follow up the issues, evidences, and concepts that it handled from the works of the referenced authors.

The treatise is also important to demonstrate the level of debate on atomism and hylomorpfism during the sixteenth century, intellectual accumulation, and the method of verification. All of this needs to be analyzed in many respects. In this regard, the author, who maintains the claims of a mutakallimün façade to a certain extent, has also used philosophical objects to develop an opposing argument as well as to create a new model that melds them into their views. In order to make his natural theory even more clear, it will be necessary to publish the treatise of "the common doubt" (al-shubhät al-ämma) that examines the space-movement relationship as complementary. 


\section{NAZARIYAT}

\section{Bibliograpy}

Aqkirmānī, Mahmad b. Hamīd Mustafā. Iqlīl al-Tarājim. Istanbul: Dāru al-Ṭibā‘āt al-'Āmira, 1266.

Aksoy, Hasan. “Müeyyedzâde Abdurrrahman Efendi”, DİA, 31, 485-86.

Altaş, Eşref. "Fahreddin er-Râzînin el-Cevherü'l-Ferd Adlı Risalesinin Tahkiki ve Tahlili," Nazariyat: İslâm Felsefe ve Bilim Tarihi Araştırmaları Dergisi 2/3 (Ekim 2015), 142-46.

Al-Āmidī, Sayf al-Dīn. Al-Mubīn fī Sharḥ al-Ma'ānī al-Alfäz al-Hukamā' wa-l-Mutakallimīn, ed. Hasan Mahsūd al-Shafĩ. Cairo: Maktabat al-Wahba, 1413/1993.

, Abkār al-Afkār, ed. Aḥmad Muhamammad Mahdī. Cairo: Dār al-Kutub, 2004.

Al-Baghdādī, Abū al-Barakāt. Kitāb al-Mu'tabar. Hyderabad: Dā’irat al-Ma'ārif al- 'Uthmāniyya, 1357.

Bulğen, Mehmet. Kelam Atomculuğu ve Modern Kozmoloji. Ankara: Türkiye Diyanet Vakfı, 2015.

, Klasik İslâm Düşüncesinde Atomculuk Eleştirileri. Istanbul: MÜ İlahiyat Fakültesi Yayınları, 2017.

Al-Jurjānī, Sayyid Sharīf. Sharḥ al-Mawāqif, ed. 'Abd al-Raḥmān Umayra. Beirut: Dār al-Jīl, 1417/1997. , Hāshiya 'alā Sharḥ al-Tajrīd. Hekimoğlu Ali Paşa 833.

Al-Juwaynī, Imām al-Ḥaramayn. Al-Shāmil fỉ Ușūl al-Dīn, ed. 'Alī Sāmi al-Nashshār, Suhayr Muhammad Mukhtār, and Fā’iz al-Badr 'Awn. Alexandria: Munsha'āt al-Ma'ārif, 1969.

Dāwūd al-Qayșarī, Nihāyat al-Bayān fì Dirāyat al-Zamān, ed. Mehmet Bayrakdar. Kayseri: Kayseri Belediyesi Yayınları, 1997.

Demir, Osman. "Dâvud el-Kayserînin Tasavvuf Metafiziğinde Zaman." Osmanli’da İlm-i Tasavvuf, ed. Ercan Alkan-Osman Sacid Arı, 431-48. Istanbul: İSAR Yayınları, 2018.

"Îcî Kelamında Fizik." İslâm İlim ve Fikir Geleneğinde Adudüddin el-Îcî, ed. Eşref Altaş, 333-84. Istanbul: İSAM Yayınları, 2017.

“Amasyalı Bir Alimin Atomculuk İncelemeleri: Müeyyedzâde ve Cüz Risalesi.” Uluslararası Amasya Alimleri Sempozyumu Bildiriler Kitabı, ed. Şuayip Özdemir and Ayşegül Gün, I, 491-500. Ankara: Amasya Üniversitesi İlahiyat Fakültesi, 2017.

Dhanani, Alnoor. The Physical Theory of Kalam, Atoms, Space and Vacuum in Basrian Mu'tazila Theology. Leiden: Brill, 1994.

Abū Zayd and Munā Aḥmad Muhammad. Al-Tasawwur al-Dharrī fỉ al-Fikr al-Falsafí al-Islāmī. Beirut: al-Mu'assasāt al-Jāmi'iyya, 1994.

Al-Ash‘arī, Abū al-Ḥasan. Maqālāt al-Islāmiyyīn wa-l-Ikhtilāf al-Mușallīn, ed. Hellmut Ritter. Wiesbaden: Franz Steiner Verlag, 1963.

Fazlığlu, İhsan, "Between Reality and Mentality: Fifteenth-Century Mathematics and Natural Philosophy Reconsidered." Nazariyat Journal for the History of Islamic Philosophy and Sciences 1, no. 1 (November 2014): 1-39.

Gökbilgin, M. Tayyib. “Müeyyed-zâde”, İA, 8, 786-90.

El-Hafidi, Moulay el-Hassen. “Müeyyedzâde b. Ali’nin el-Havâşî alâ Şerhi'l-Mevâkıf Adlı Eserinin Kelamdaki Önemi.” Yüksek lisans tezi, Çanakkale Onsekiz Mart Üniversitesi, 2014.

Ibn Fūrak, Mujarrad Maquāāt al-Shaykh Abū al-Hasan al-Ash'arī, ed. Daniel Gimaret. Beirut: Dār al-Mashriq, 1987.

Ibn Hazm. Al-Fașl fi-l-Milal wa-l-Ahwä' wa-l-Niḥal, ed. 'Abd al-Raḥmān 'Umayra and Muhammad Ibrāhīm Nusayr. Beirut: Dār al-Jīl, 1996/1416.

Ibn Mattawayh. Al-Tadhkira fî Aḥkām al-Jawāhir wa-l-A'rāḍ, ed. Daniel Gimaret. Cairo: Ma'had al-'Ilm al-Faransī, 2009.

Ibn Sīnā. Al-Ishārāt wa-l-Tanbīhāt, ed. Sulaymān Dunyā. Egypt: Dār al-Ma‘ārif, n.d.

, Kitāb al-Najāt, ed. Mājit Fakhrī. Beirut: Manshūrāt al-Āfāq al-Jadīda, 1982.

, Kitāb al-Shifã', al-Ṭabīinyyāt I: al-Simâ' al-Ṭabīî̀, ed. Said Zāyed. Qum: Menshūrāt Āyatallāh al-Uzmā alMar'āshī al-Najī, 1409. 
, 'Uyūn al-Hịkma, ed. 'Abd al-Raḥmān al-Badawī. Beirut: Dār al-Qalam 1980.

Al-İjī, 'Aḍud al-Dīn. Kitāb al-Mawāqif (with Sharḥ al-Mawāqif), ed. 'Abd al-Raḥmān 'Umayra, 1-3. Beirut: Dār al-Jīl, $1417 / 1997$.

İnanır, Ahmet. "Müeyyedzâde Abdurrahman Efendi'nin Hayatı ve Osmanlı Hukuk Geleneğindeki Yeri," Uluslararası Amasya Âlimleri Sempozyumu Bildiriler Kitabı, ed. Şuayip Özdemir ve Ayşegül Gün, 1, 339-47. Ankara: Amasya Üniversitesi İlahiyat Fakültesi, 2017.

Al-Ișfahānī, Shams al-Dīn, Mațāli‘ al-Anẓār. Istanbul: Shirkat-i ‘Ilmiyya, 1305/1887.

Kâdî Abdülcebbâr. Nedensellik Kitabr: Kitâbü't-Tevlîd min Kitâbi'l-Muğnî, tran. Osman Demir. Istanbul: Klasik Yayınları, 2015.

Kātib Celebi. Khasf al-Zunūn 'an Asāmī al-Kutub wa al-Funūn, ed. M. Şerefettin Yaltkaya. Ankara: Milli Eğitim Bakanlığı, 1941.

al-Kafawī, Maḥmūd b. Sulaymān. Katā'ib A'lām al-Ahyār min Fuqahā’i Madhhab al-Nu'mān al-Mukhtār, ed. Saffet Köse, Murat Şimşek, Hasan Özer, Huzeyfe Çeker, and Güneş Öztürk. Istanbul: Maktabat al-Irshād, 1438/2017.

al-Quțb al-Dīn al-Rāzī. al-Muhākamāt bayna Sharḥay al-Ishārāt. ed. Karīm Faizā. Qum: Matbū‘āt-i Dīnī, 1383/2004.

Muayyadzāda, Abd al-Raḥmān Efendi. Fī al-Shubhat al-ĀĀmma. Süleymaniye Library, Köprülü 1596, 142a-147a.

Al-Nīsābūrī. Al-Masā’il fì al-Khilāf bayna al-Bașriyyīn wa al-Baghdādiyyīn, ed. Ma‘n Ziyāda and Rıdvān al-Sayyid. Beirut: Ma'had Inmā' al-`Arabī, 1979.

Pfeiffer, Judith. "Teaching the Learned: Jalāl al-Dīn el-Dawwāni’s Ijāza to Mu'ayyadzāda Abd al-Rahmān Efendi and the Circulation of Knowledge Between Fars and Ottoman Empire at the Turn of the Sixteenth Century." The Heritage of Arabo-Islamic Learning: Studies Presented to Wadad Kadi, ed. Maurice A. Pomerantz and Aram Shanin, 309-11. Leiden \& Boston: Brill, 2015 [2016].

Pines, Shlomo. İslâm Atomculuğu. Tran. Osman Demir. Istanbul: Klasik Yayınları, 2017.

Al-Rāzī, Fakhr al-Dīn. al-Mațālib al-Āliya min 'Ilm al-Ilāhī, ed. Aḥmad Hijāzì al-Sakkā. Beirut: Dār al-Kitāb al-Arabī, 1987.

, Al-Mabāḥith al-Mashriqiyya fì 'Ilm al-Ilāhiyyāt wa al-Tabī'iyyāt, ed. M. Mu'tasim-Billāh al-Baghdādī. Beirut: Dār al-Kitāb al-'Arabī, 1990.

, Sharh al-'Uyūn al-Hikma. Tehran: Mu’assasat al-Ṣādiq, 1415.

al-Samarqandī, Shams al-Dīn. al-Saḥa’if al-Ilāhiyya, ed. Aḥmad 'Abd al-Raḥmān Sharīf. Kuwait: Maktabat al-Falāh, 1985.

Sinān Pasha. Jawābu Sinān Pasha an 'I'tirāḍ al-Qasțallānī fì Bahth al-juz' alladhī lā Yatajazza'. Süleymaniye Library, Hasan Hüsnü Paşa 600, 92a.

al-Ṭūsī, Nașīr al-Dīn. Sharh al-Ishārāt wa al-Tanbīhāt, ed. Sulaymān Dunyā. Egypt: Dār al-Ma'arif, n.d.

, "Taḥrīr al-Ukar li-Thāwudhūsyus”, in Majmū'al-Rasẩil (Hyderabad: Mațbā'at Dā’irat al-Ma'ārif al-'Uthmāniууа, $1358 \mathrm{AH}$.

, "Taḥrīr al-Kurat al-Mutaḥarrika li-Awtūlūqus," in Majmū'al-Rasā'il (Hyderabad: Mațbāatat Dā'irat al-Ma'ārif al-'Uthmāniyya, 1358 AH.

, Tahrîru Usûli'l-hendese ve'l-hisâb: Eukleides'in Elemanlar Kitabının Tahriri, prep. İhsan Fazlıoğlu, Istanbul: İstanbul Yazma Eserler Kurumu Başkanlığı, 2012.

, Tahrīr Uqlìdis fi-l-Ușūl al-Handasa wa-l-ḥisāb, Beyazıd Devlet Library, Veliyyüddin Efendi MS 2304.

Taşköprīzāde Aḥmad Efendi. al-Shaqã’iq al-Nu'māniyya fì 'Ulamã’ al-Dawlat al-'Uthmāniyya. Beirut: Dār al-Kitāb al'Arabī, 1395/1975

al-Taftāzānî, Sa'd al-Dīn, Sharḥ al-Maqāsid. Beirut: 'Ālam al-Kutub, 1998.

el-Urmawî, Sirāj al-Dīn. "Mațāli‘ al-Anwār," ed. Hasan Akkanat. "Kadı Siraceddin el-Ürmevi ve Metaliu'l-Envar I (tahkik, çeviri, inceleme)," Hasan Akkanat. Doctoral Dissertation, Ankara Üniversitesi, 2006.

Uzunçarşılı, İsmail Hakkı. Osmanlı Tarihi, 2, 657-60. Ankara: Türk Tarih Kurumu Basımevi, 1949. 


\section{Critical Edition}

$$
\begin{aligned}
& \text { / [ • اظ] بسم اللهّ الرحمن الرحيم } \\
& \text { وبه نستعين }
\end{aligned}
$$

قال صاحب المواقف في بحث الجزء الذي لا يتجزّأ: (انفرض كرةً تُمّسّ سطحًا مستويا فما به

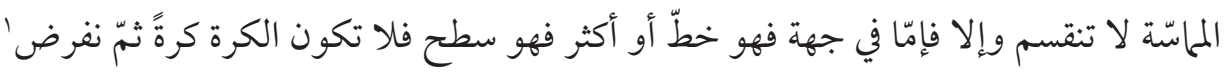

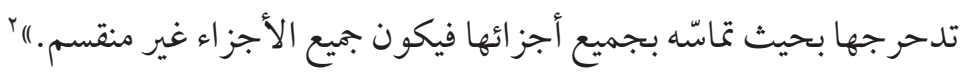
وقال الشارح المحقّق العلّامة أحسن بّ إكر امه في دار المُقامة:

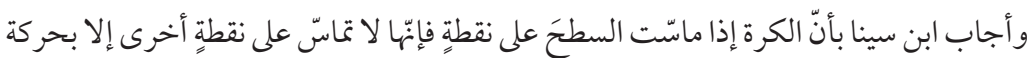

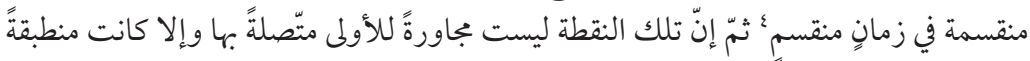

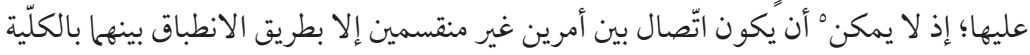

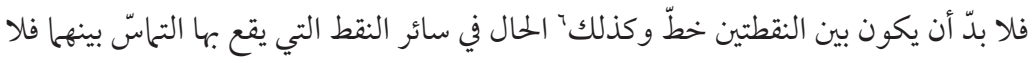

$$
\text { يكون محيط الكرة ولا السطح المستوي مركّبا من نقطِ متتالية. }
$$

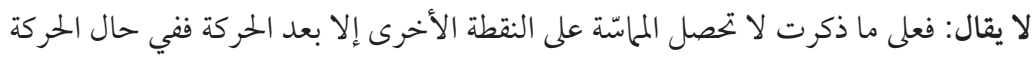

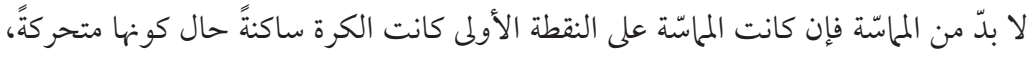

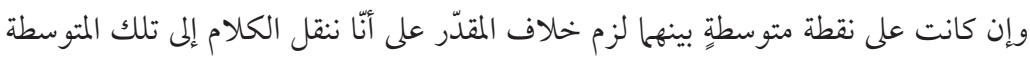

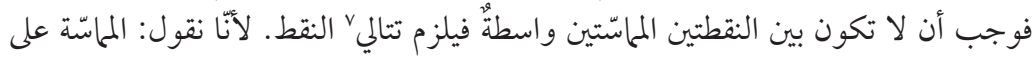

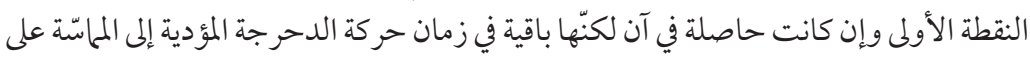

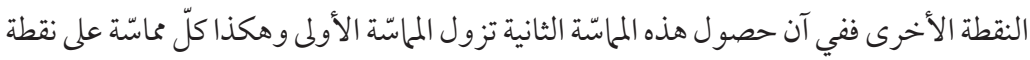

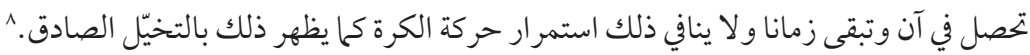

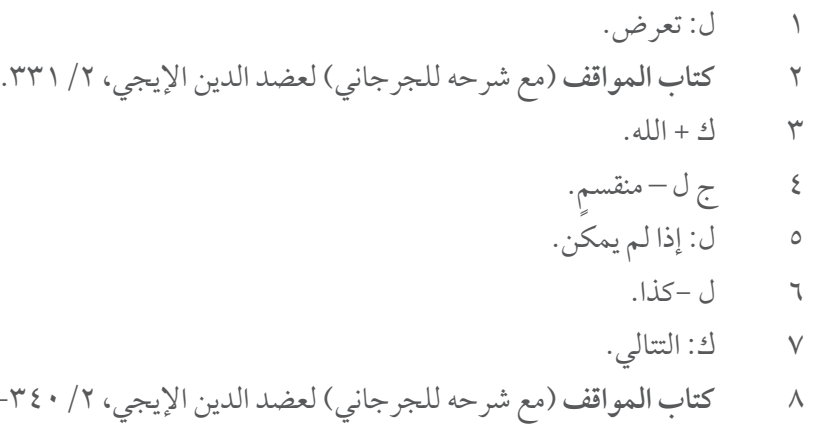




\section{أقول: بقاء التماسّ بنقطة ما زمانًا باطل بوجوه:}

الأوّل: برهن في أوّل 'ا كتاب الأكر على أنّه إذا ماسّت كرةٌ سطحًا مستويًا فالقطر الخارج من

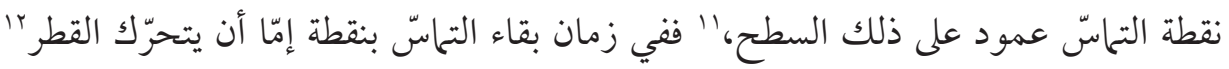

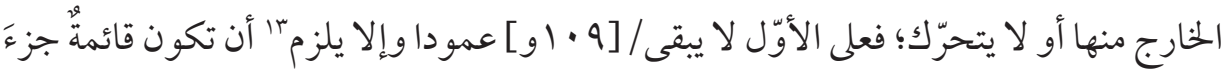

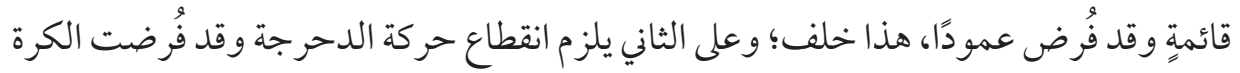
متدحرجة، هذا خلف أيضًا.

الثاني: برهن في الكرة المتحرّكة على \&' أنّه إذا دارت الكرة دورانًا معتدلًا قطعت جميعُ النقط التي

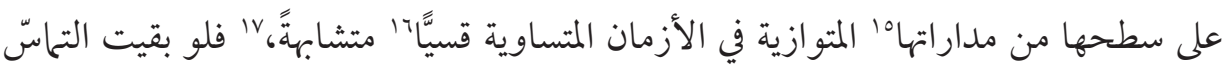

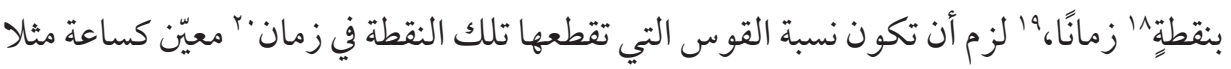

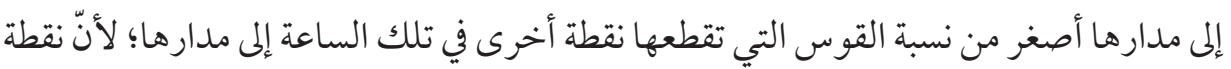

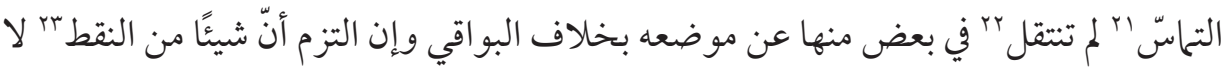

\section{9 \\ 1.}

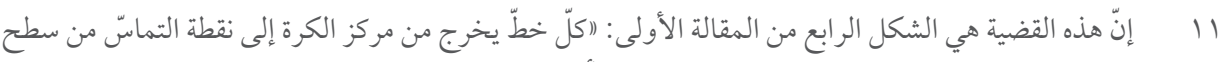

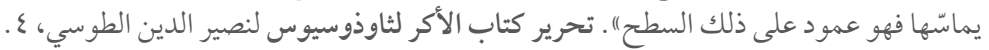

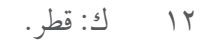

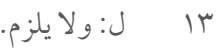
إ: 10 $\quad$ ك: 10

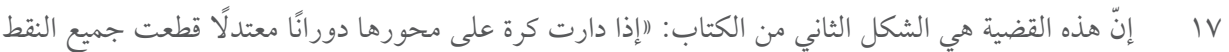

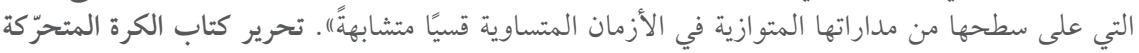

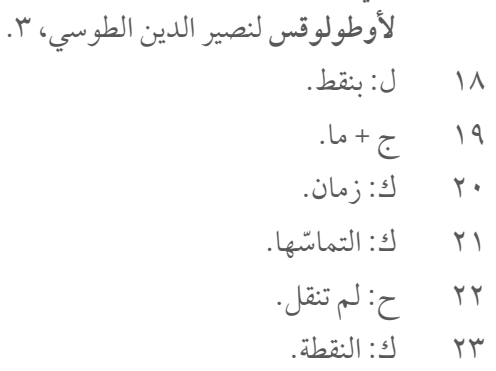




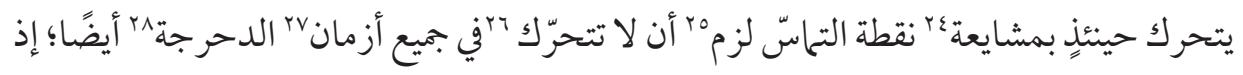

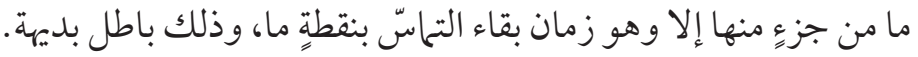

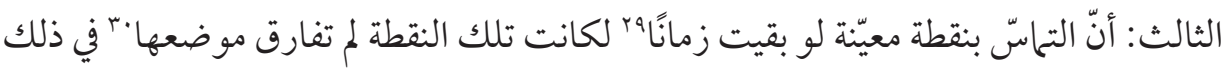

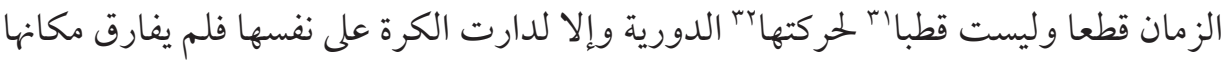

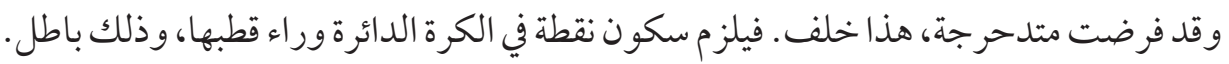
الر ابع: نرسم دائرةً عظيمةً على الكرة تمرّ بنقطتي التماسّ، ثمّ نفرض حركة الكرة عليها وعلى

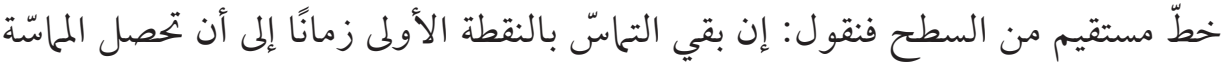

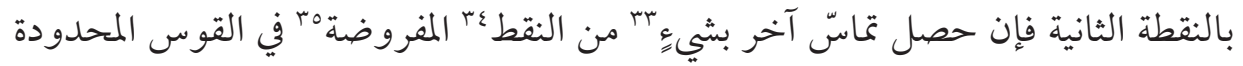

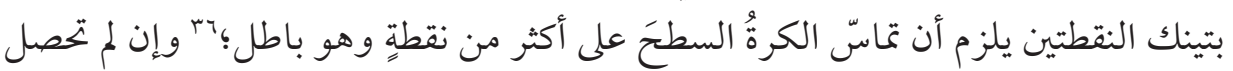

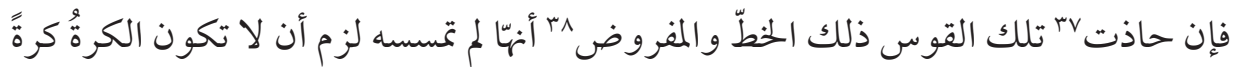

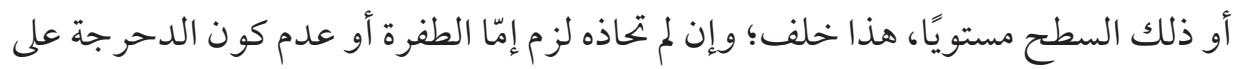

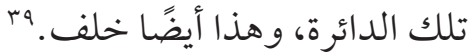

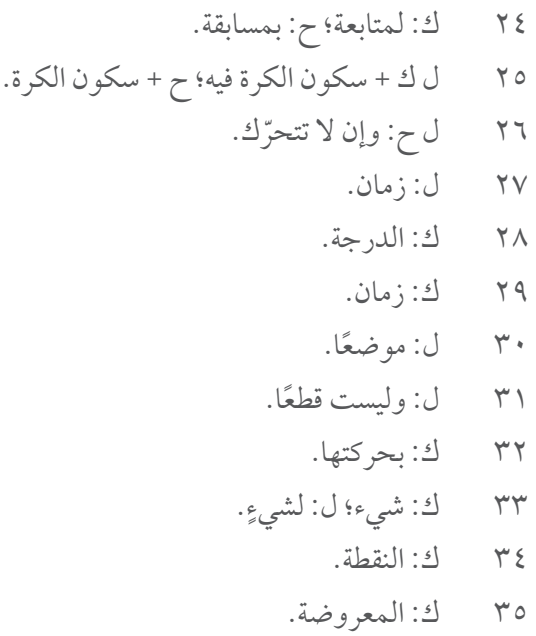

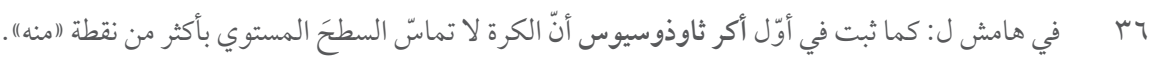

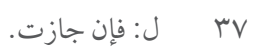

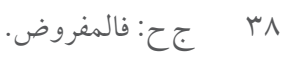

هץ في هامش ل: وهو مبرهن عليه عندنا تركنا ذكره مخافة التطويل (منه)". 
كلّ نقطة تفرض بين نقطتي التهاسّ في القوس المحدودة بهها. فهي أقرب إلى السطح من

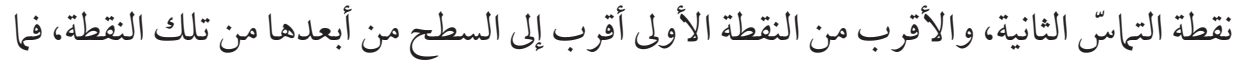

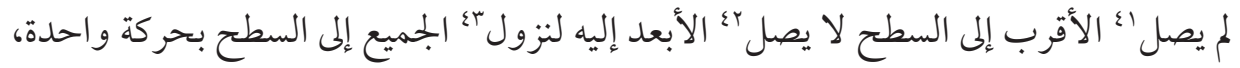
فلا تبقى نقطة في تلك القوس لا تماسّ السطح، فلا يمكن أن يكون التحاسّ بنقاط غير متتالية

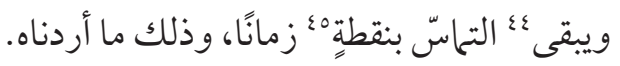

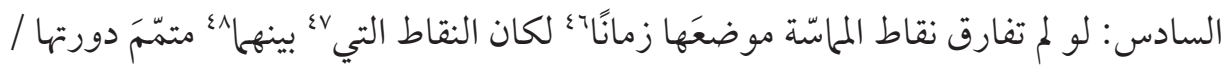

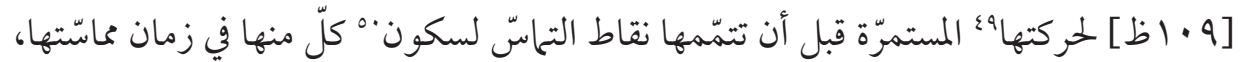

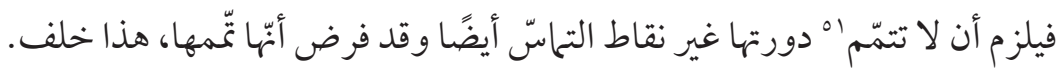
السابع: الزاوية التي تحدث بين منطقة الكرة وبين الخطّ المستقيم الذي على السطح لا تقبل

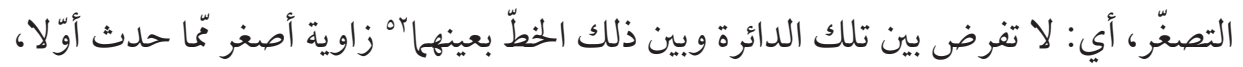

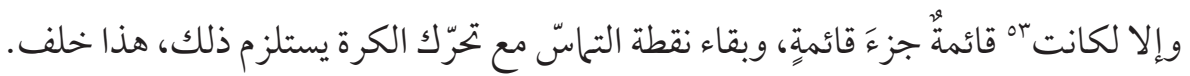
الثامن: لو بقي التحاسّ بالنقطة الأولى إلى عه أن يحصل التهاسّ بالثانية ثمّ زال في آن التحاسّ بالثانية

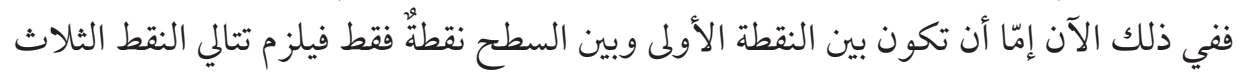

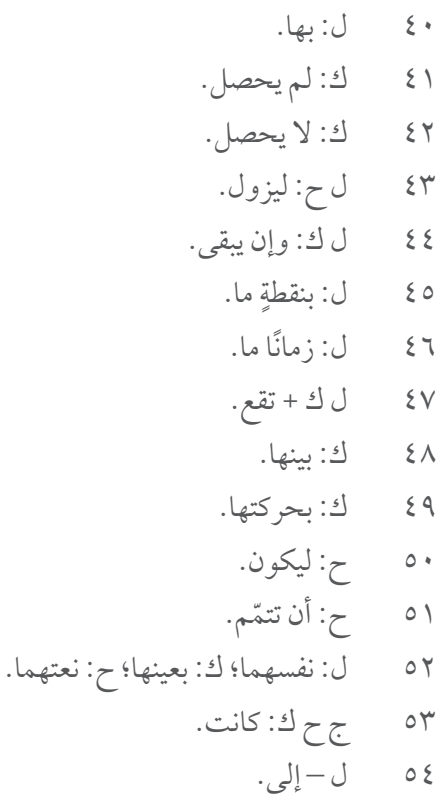




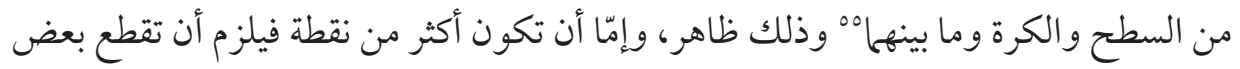

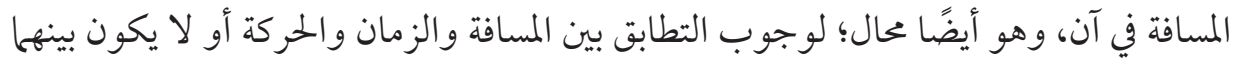

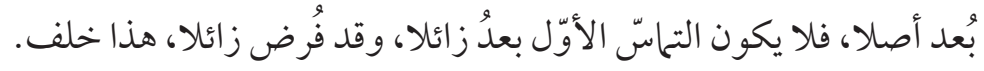

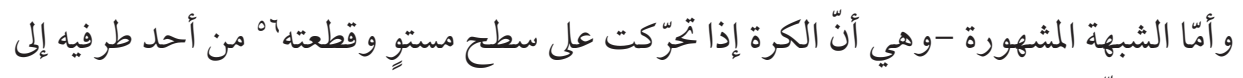

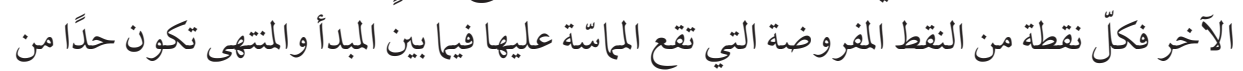

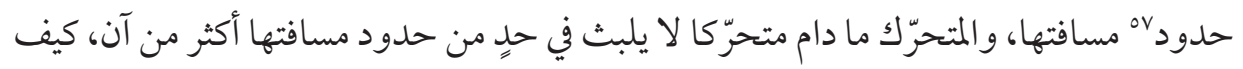

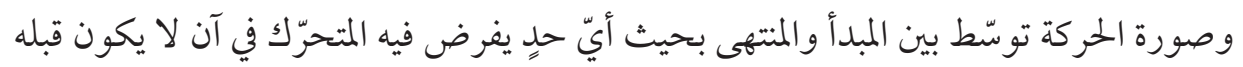

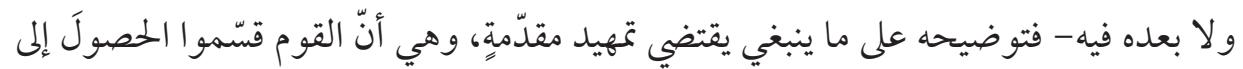

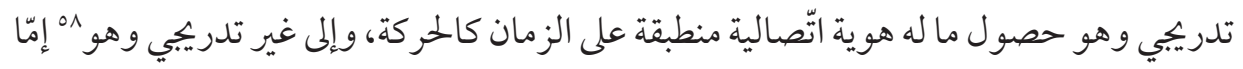

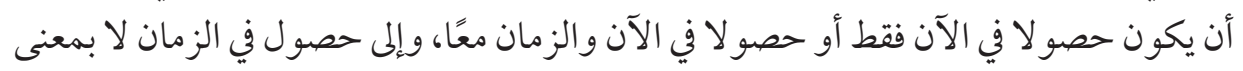

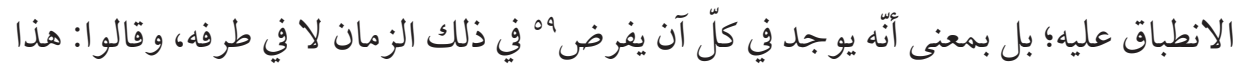

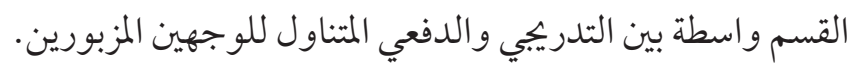

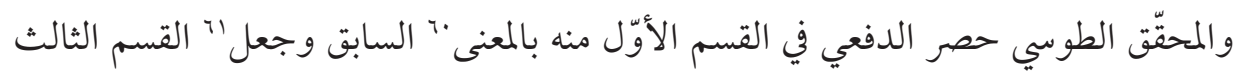

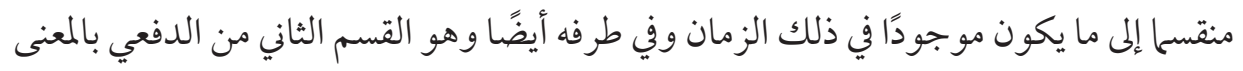

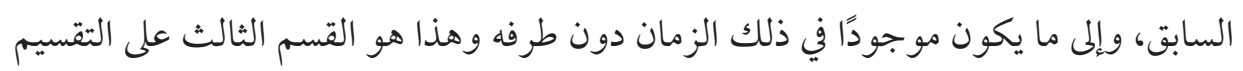

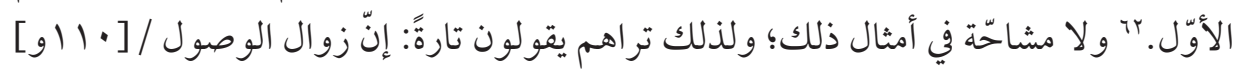

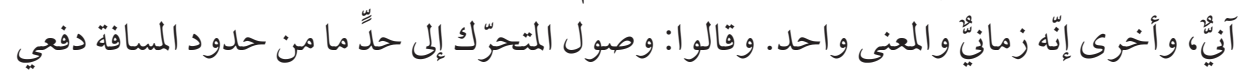

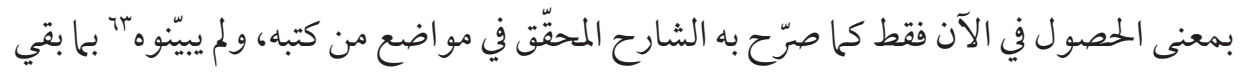

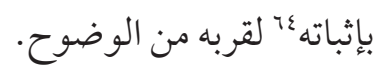

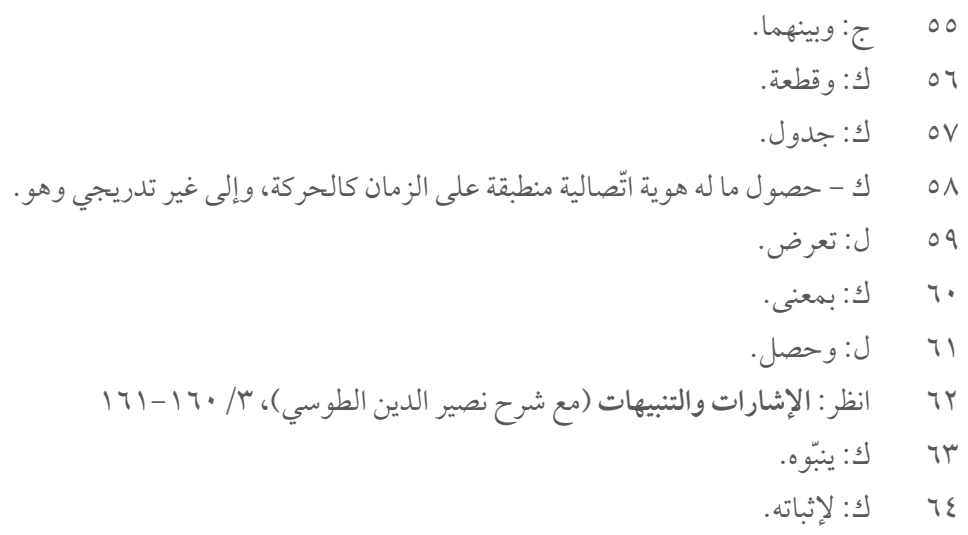




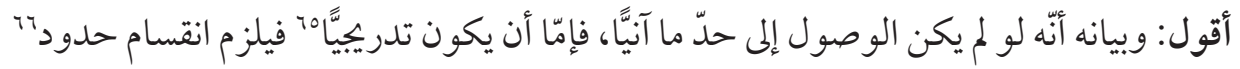

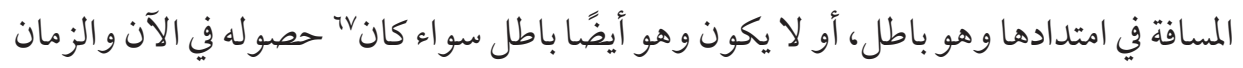

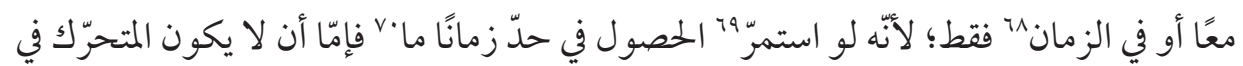

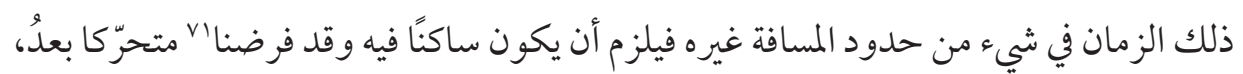

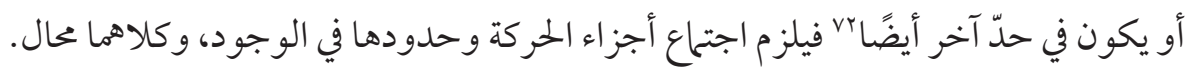

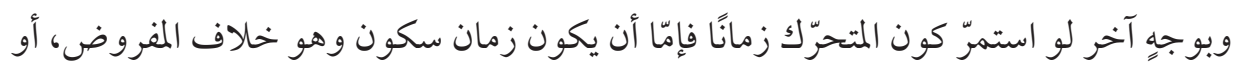

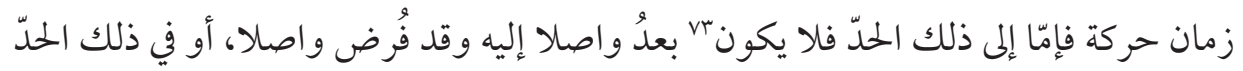

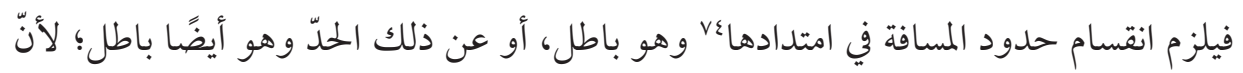

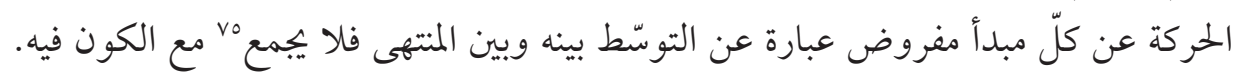

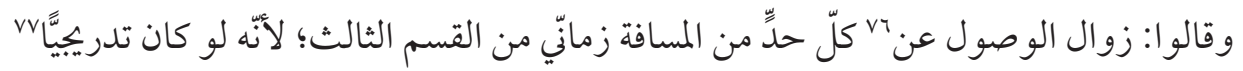

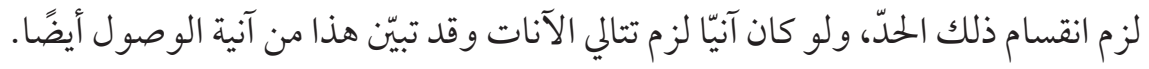
إذا تمهّد هذا فنقول: إذا تدحرجت الكرة على سطح مستوِ فكلّ نقطة من نقاط التحاسّ الواقع بين

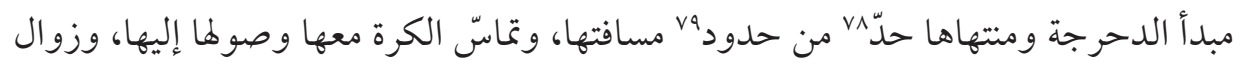

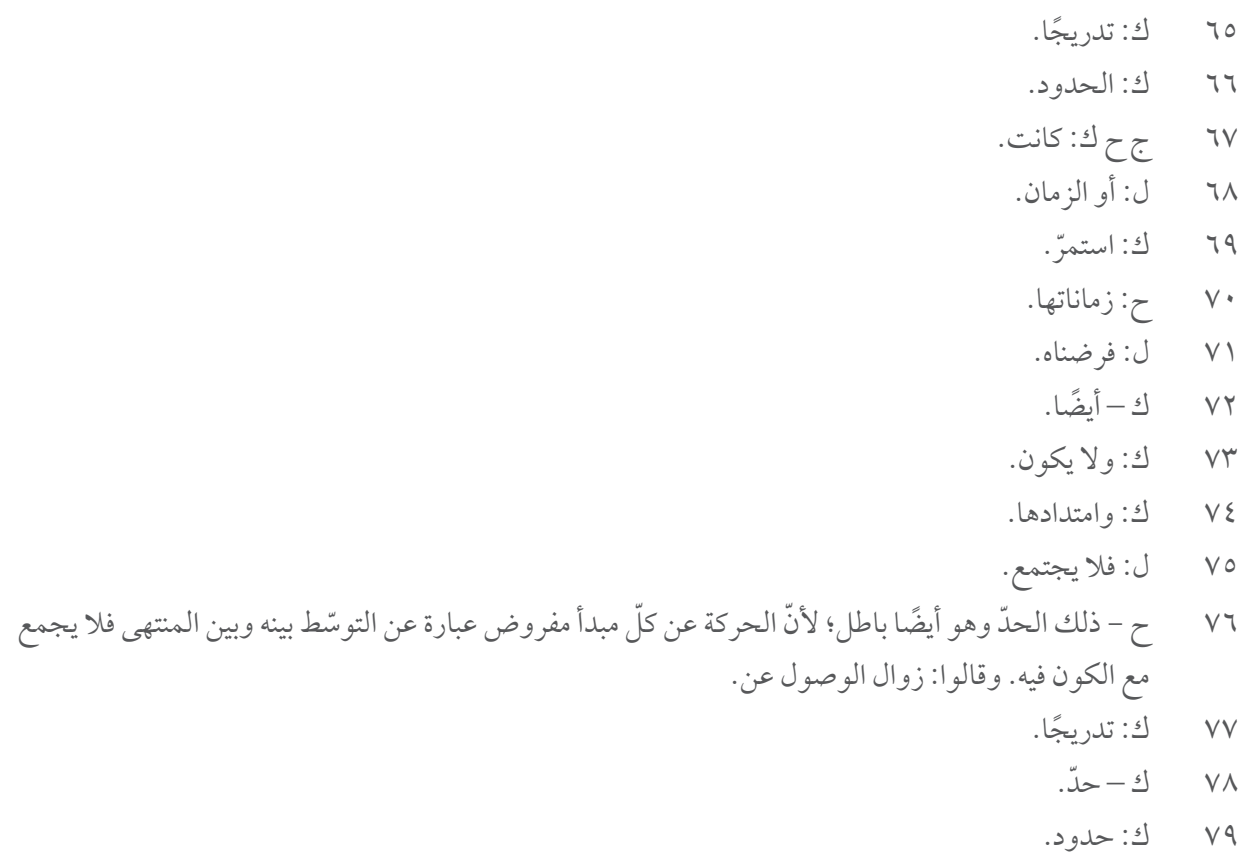




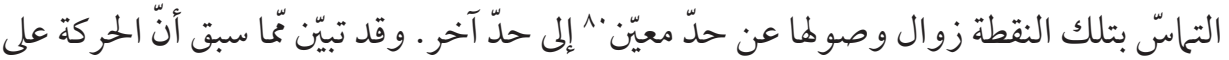

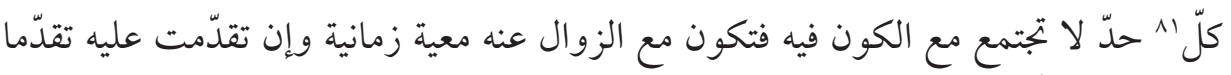

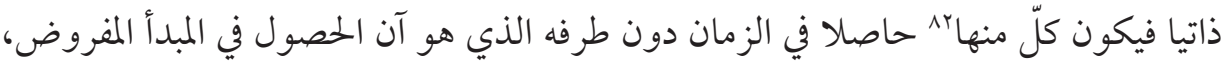

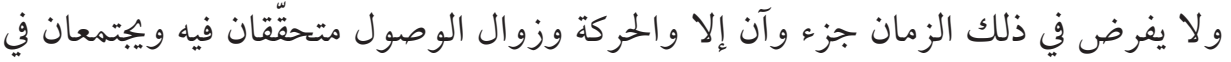

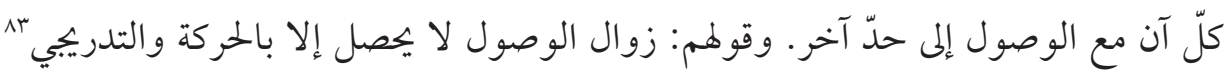

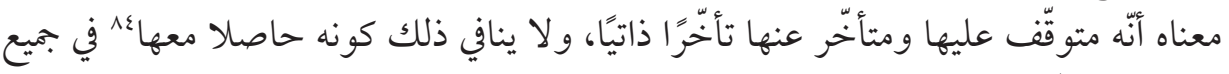

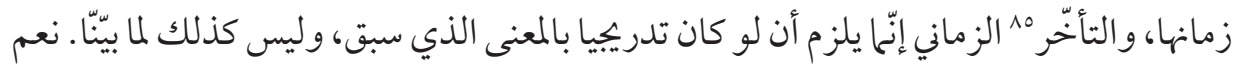

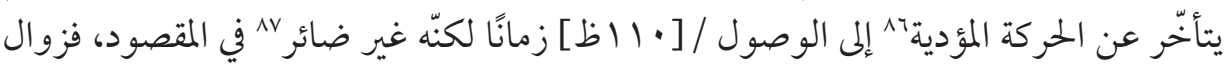

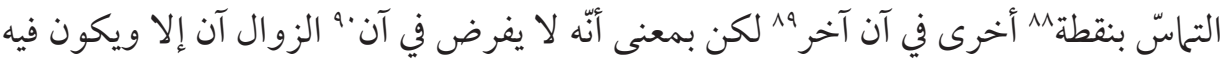

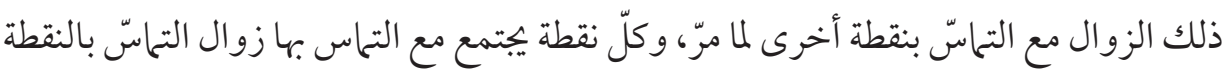

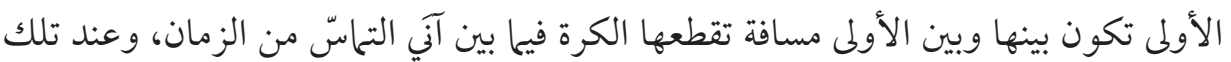

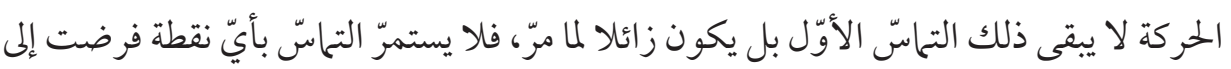

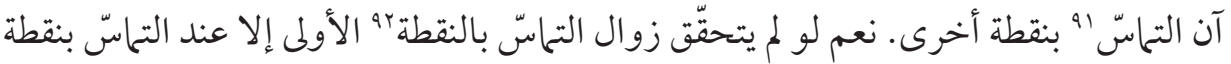

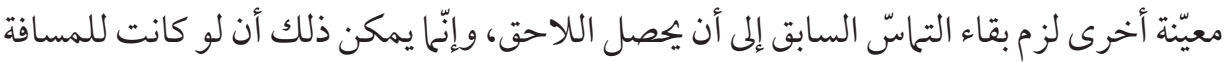

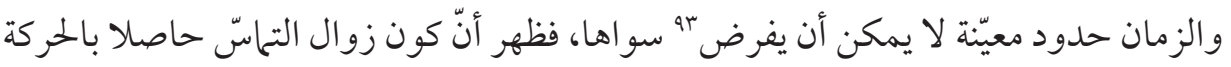

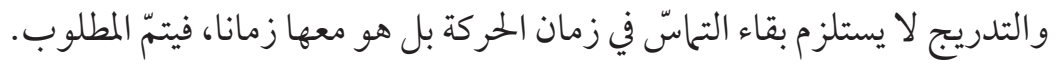

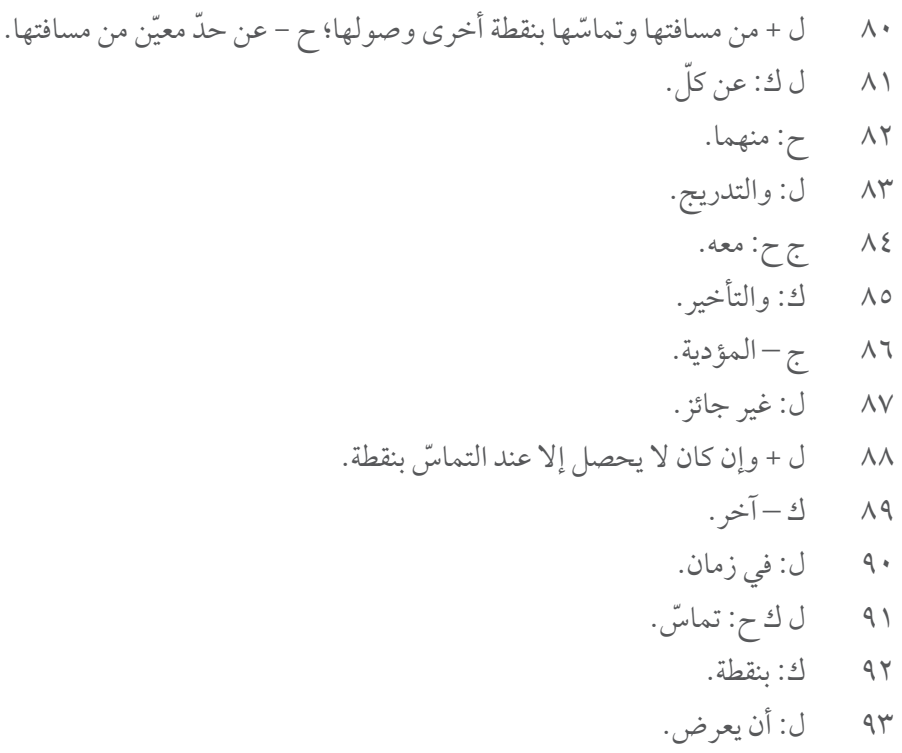


أقول: وبهذا يندفع ما يتوهّمَّه من أنّ كلّ نقطة تفرض

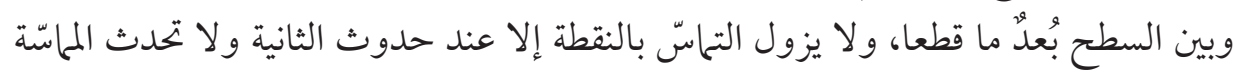

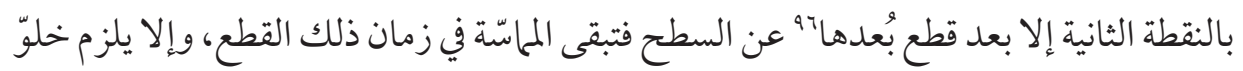

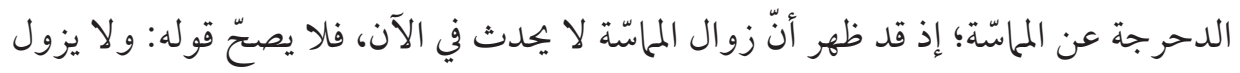

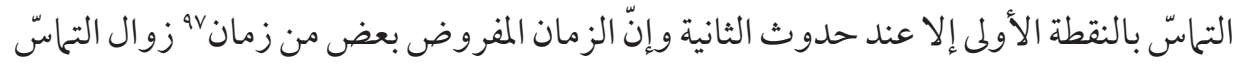

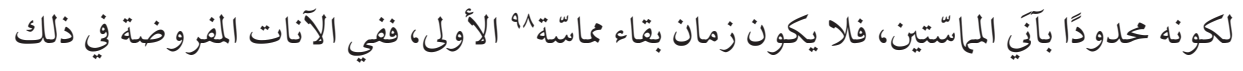

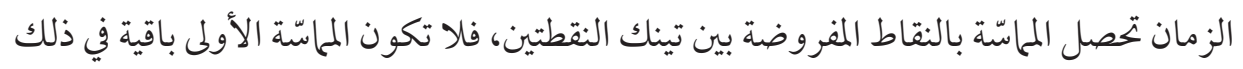

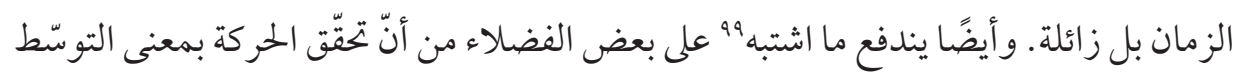

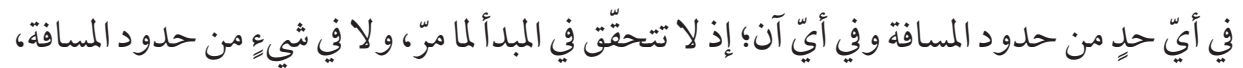

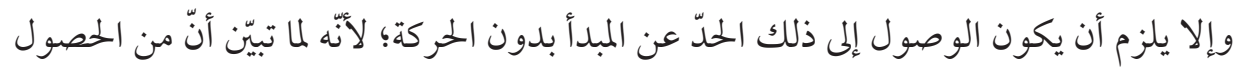

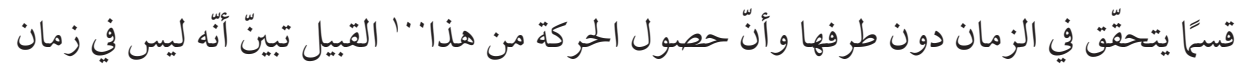

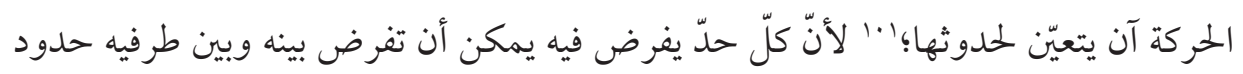

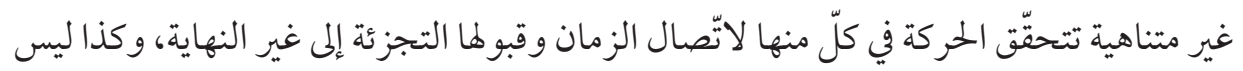

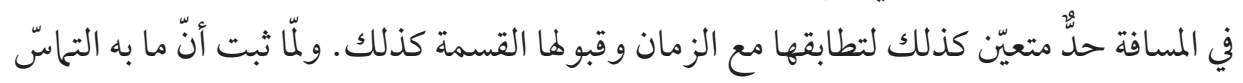

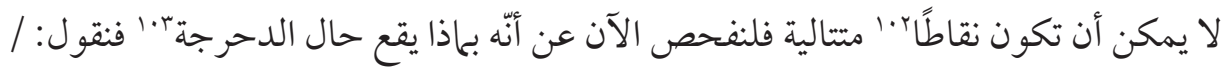

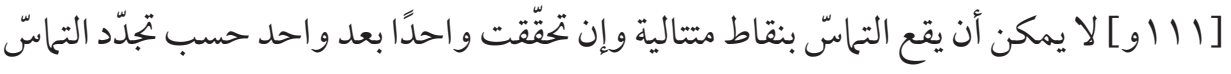

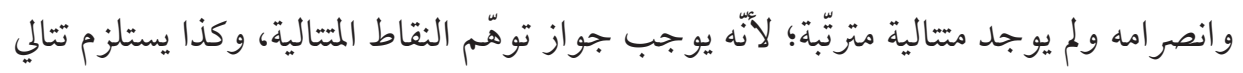

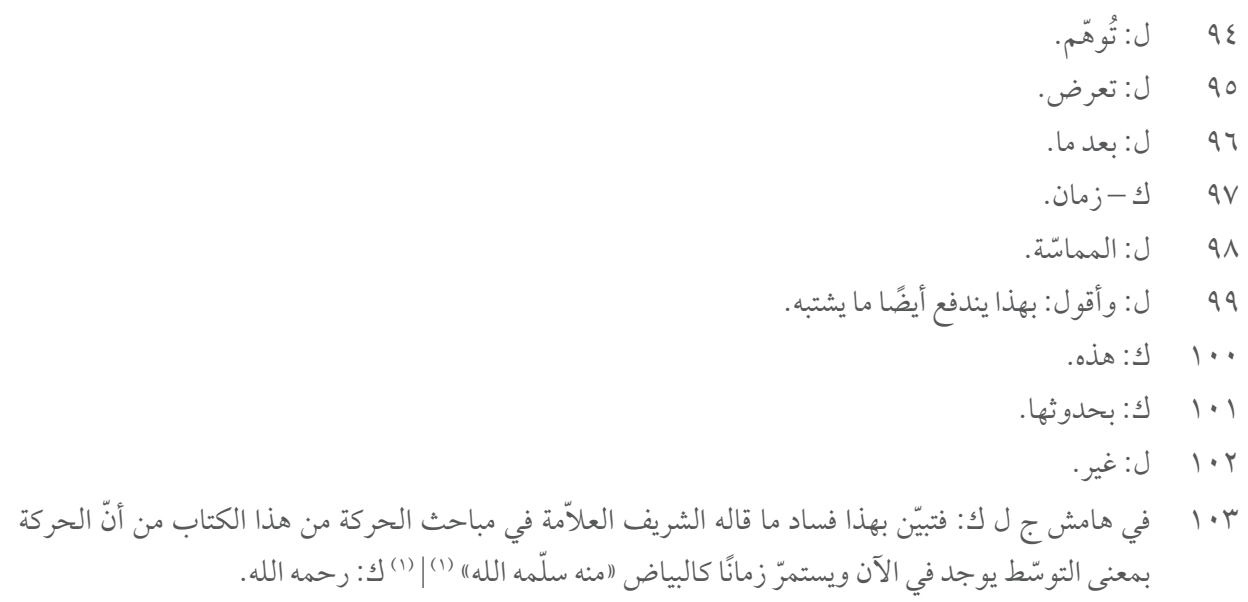


الآنات، وكلّ منهها كافٍ في إثبات الجزء ولا أن يقع مع نقطة سيّالة شخصيته ؛ُ مستمرّة من أوّل

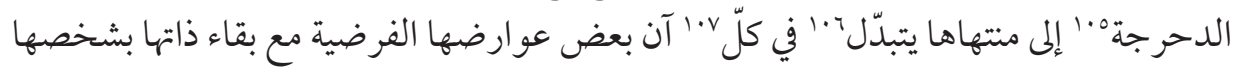

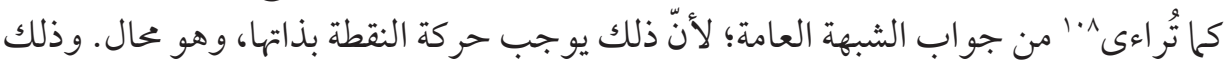

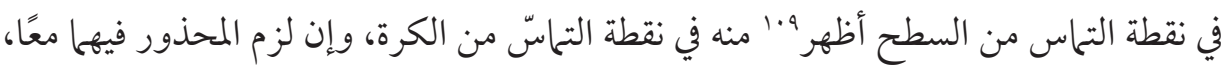

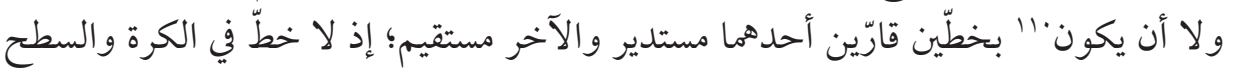

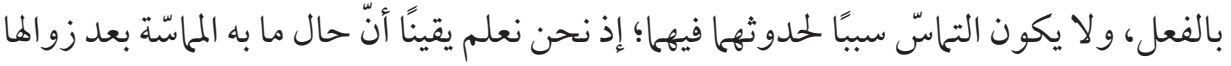

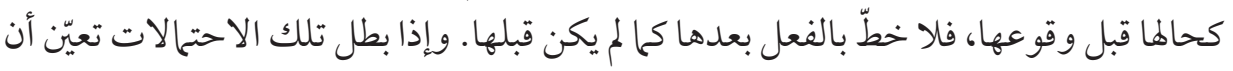

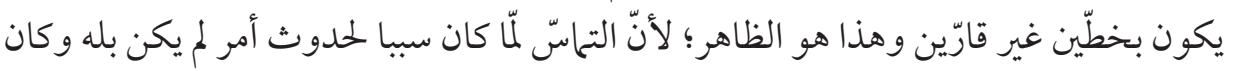

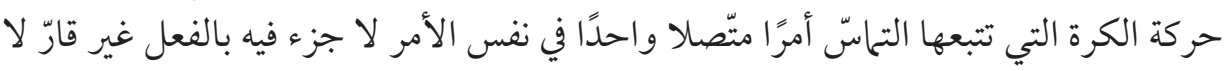

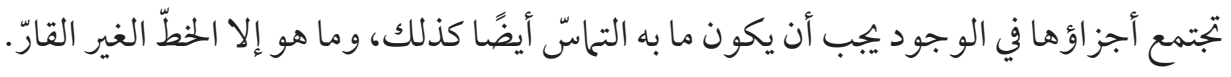
و الشيخ أورد في الشفاء فصلا طويل '" الذيل لإثبات أنّ الحركة والزمان متّصلان ليس لهما أوّل

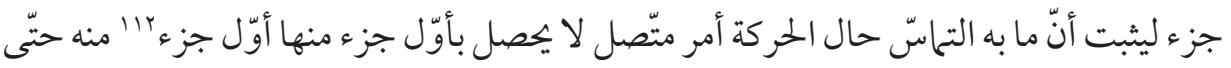
يكون نقطة، و كان ذلك بعد أن قال:

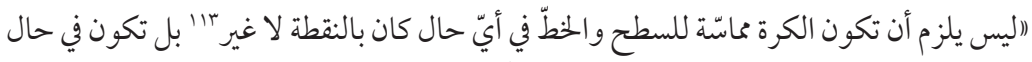

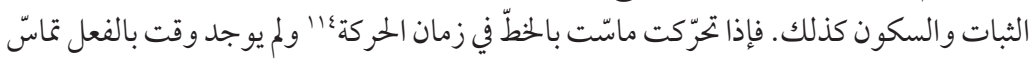

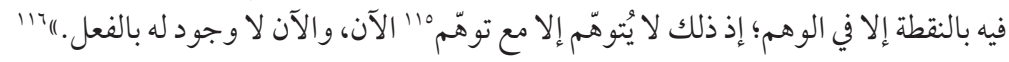

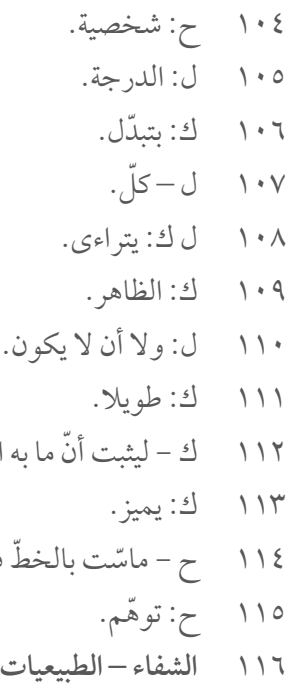


ولا يتو هّمنّ أنّ هذا الجو اب إنّما يتأتّى بعد انتفاء الجزءء، وليس الكلام إلا فيه؛ لأنّه يكفي الحكيم

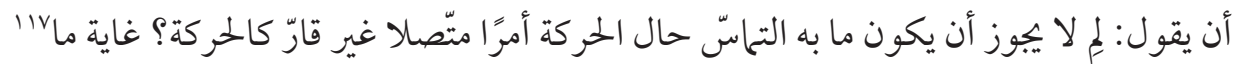

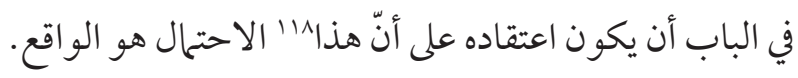

$$
\begin{aligned}
& \text { أقول: في هذا الجواب إشكالان. }
\end{aligned}
$$

الأوّل: أنّ وجود مثل هذا الأمر الغير القارّ غير معقول كما بيّه الشريف المحقّق أخذا من كلام

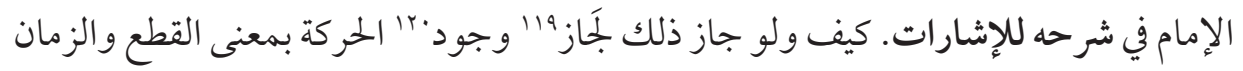

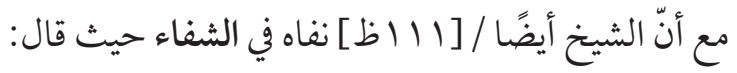

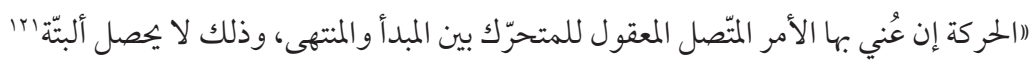

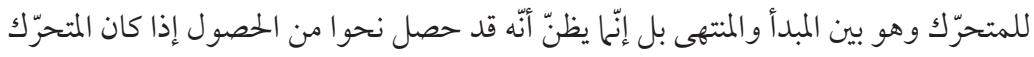

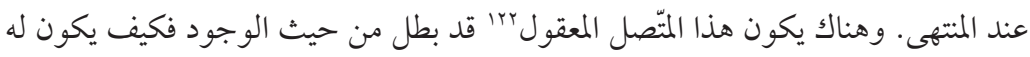

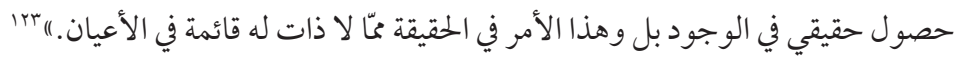

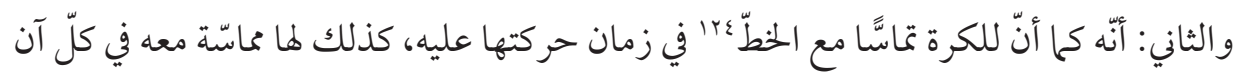

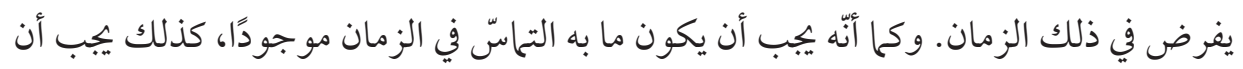

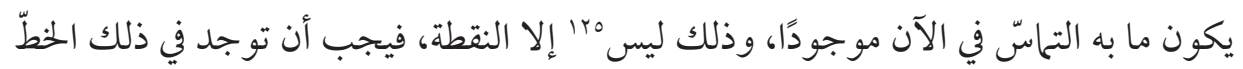

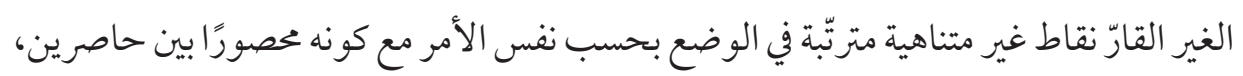
وذلك محال متتالية كانت أو لا.

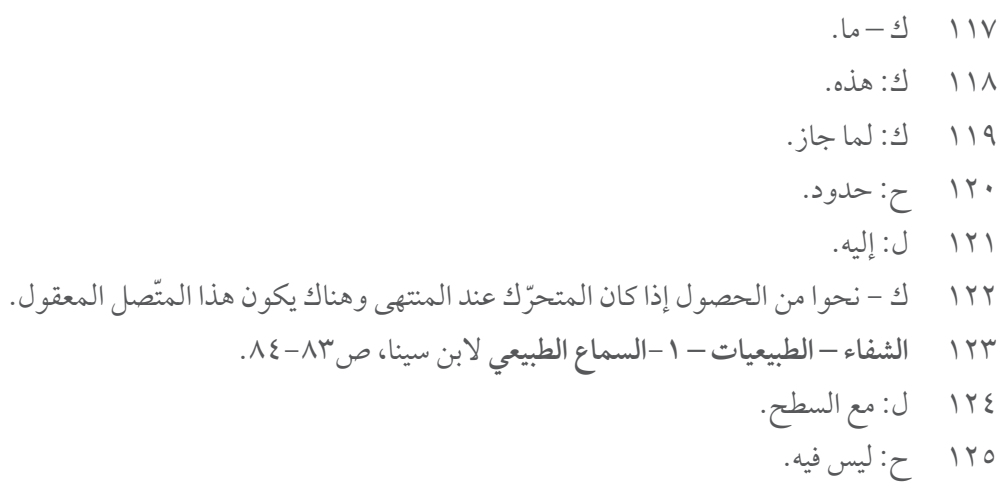


قوله: (الم يكن ألبّة وقت بالفعل يهاسّ فيه بالنقطة إلا في الوهم؛؛ إذ ذلك لا يُتوهّم إلا مع توهّم

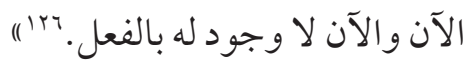

قلت: وقوع التهاسّ في الآن بحسب نفس الأمر كافٍ في إثبات تلك النقطة، سواء كان الآن

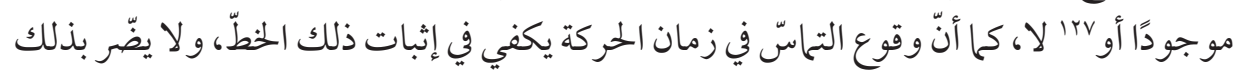
كون الزمان أو الحركةمبا موهومًا.

لايُقال: مثل هذا الإشكال وارد على خطّهُ 1 يمكن أن تفرض فيه نقاط غير متناهية. قلت: الوهم لا يقدر على استحضار ‘rا أمور غير متناهية فيكون ما يخرج بسببه من القوّة إلى الفعل

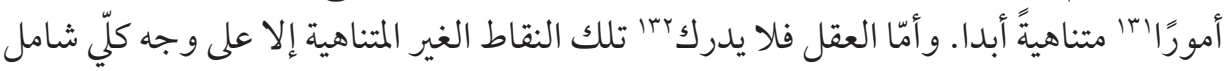

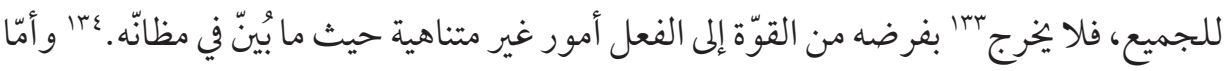

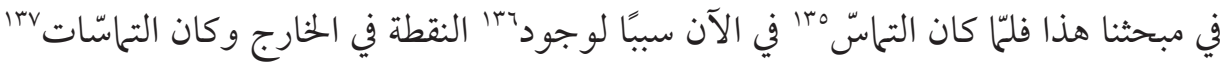

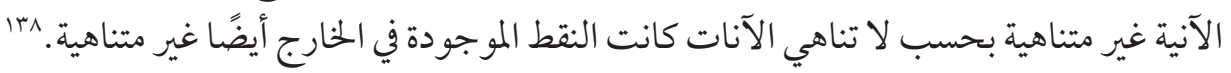
أقول: الجو اب الحقّ الذي لا عَيد هَ" عنه يقتضي تمهيد مقدّمة هي أنّ مبنى هذا الدليل وكثير من

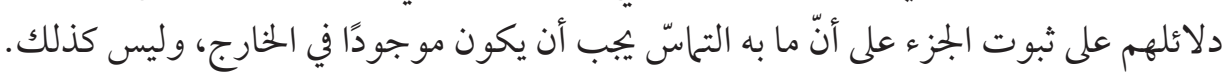

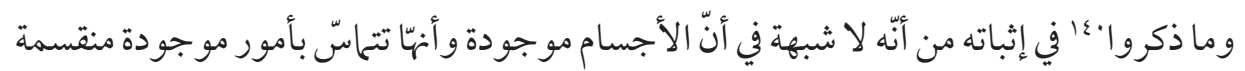

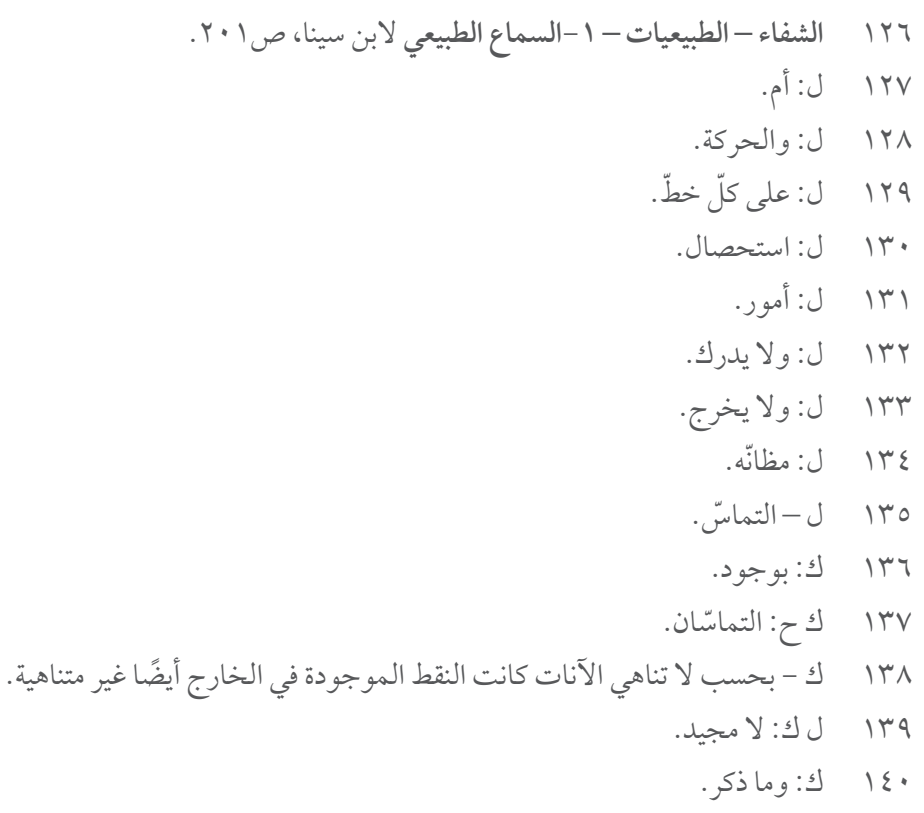




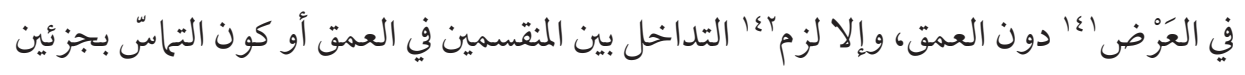

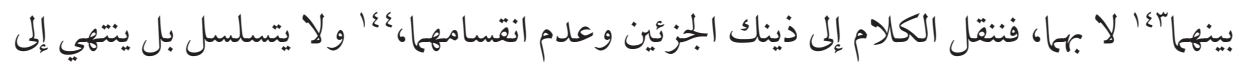

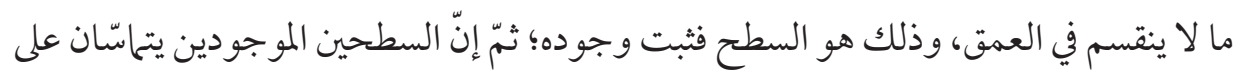

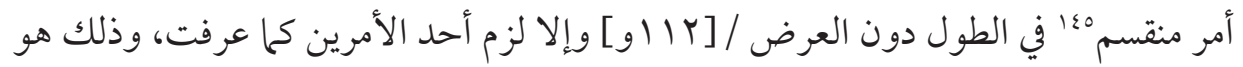

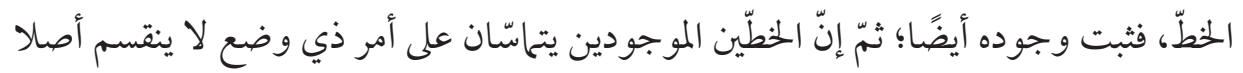

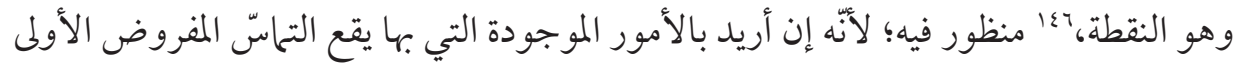

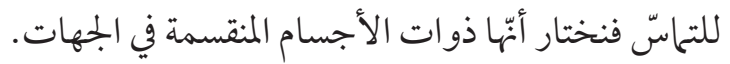

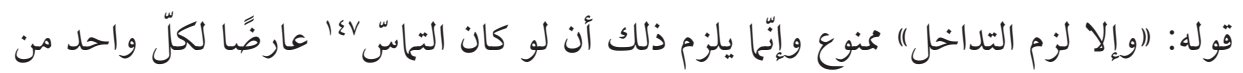

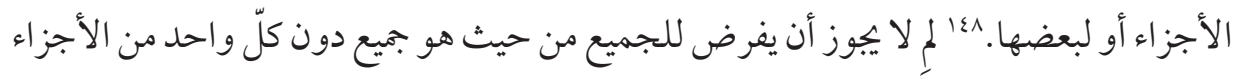

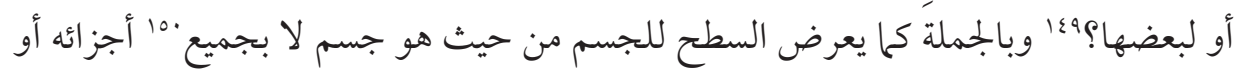

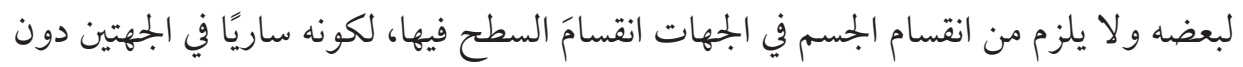

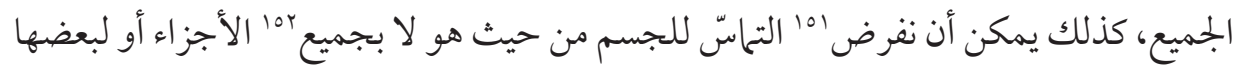

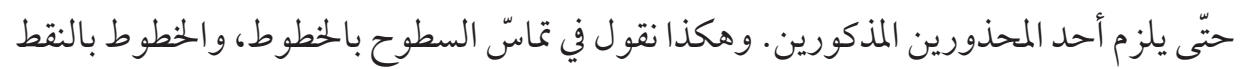

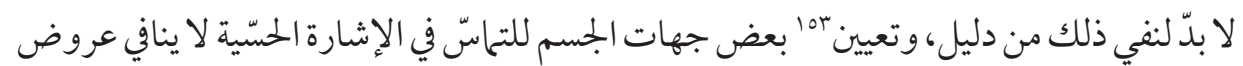

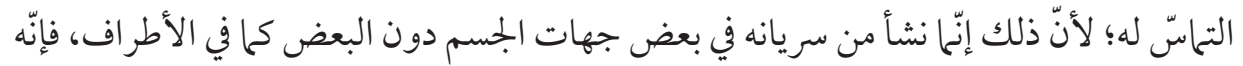

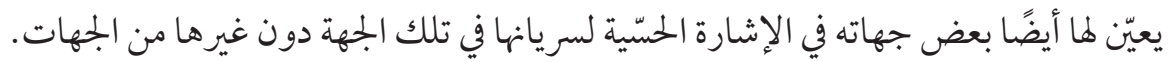

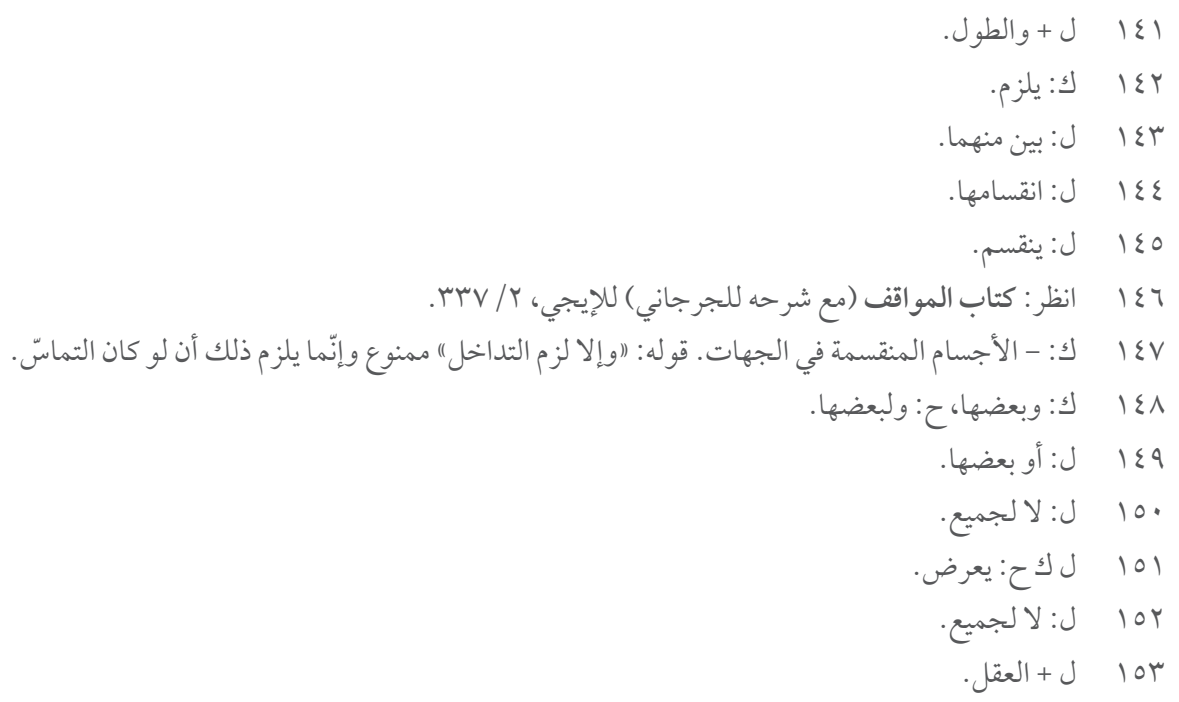


وأقول: إذا أريدعا بها به 100 التهاسّ المفروض الأولى للتماسّ ولم يتوجّه هذا المنع على الدليل لزم

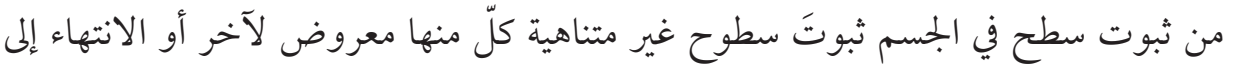

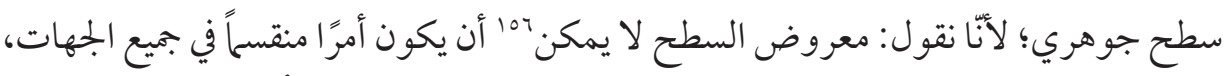

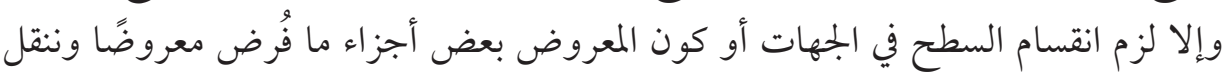

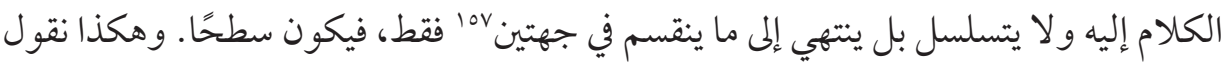
في ذلك السطح أيضًا فيتسلسل أو ينتهي إلى سطح جوهري.

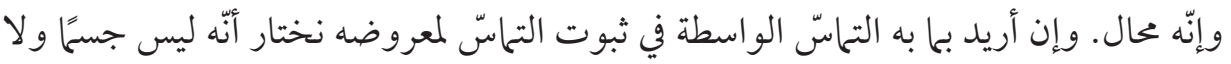

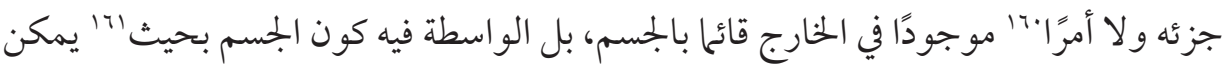

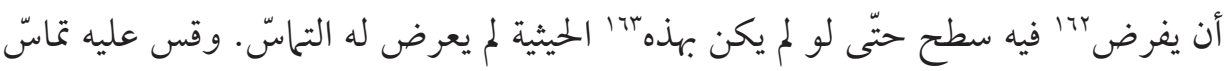

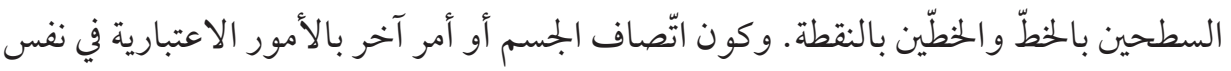

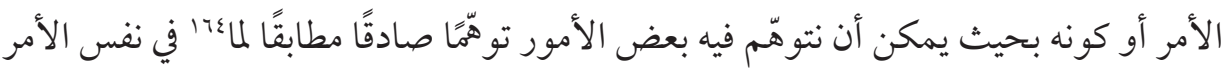

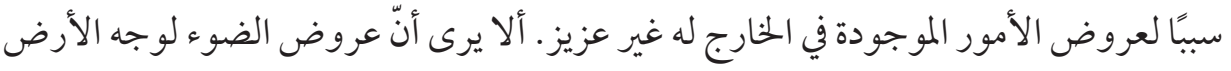

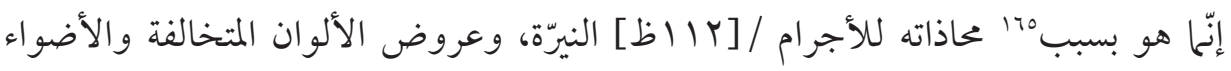

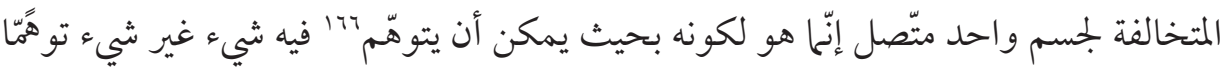

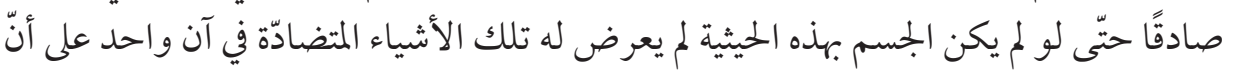

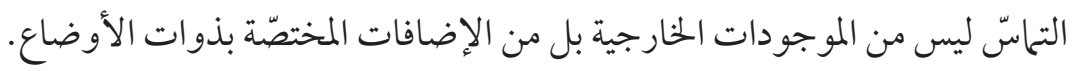

إذ

100 100

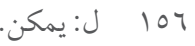

10V

101 في هامش ك: هذا بيان لزوم السطوح الغير المتناهية أو الانتهاء إلى سطح جوهري.

أول: 109

17 .

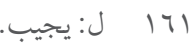

(r

عا7 ال: بهذا؛ ح:لهذه.

ع7ا لك: بما.

170

17 إك: ليتوهّم. 


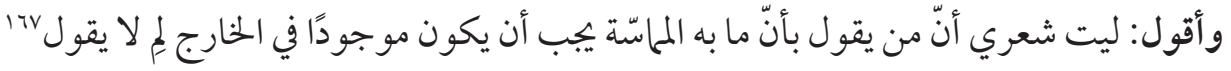

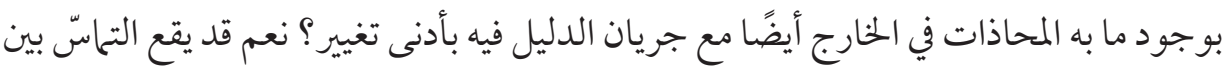

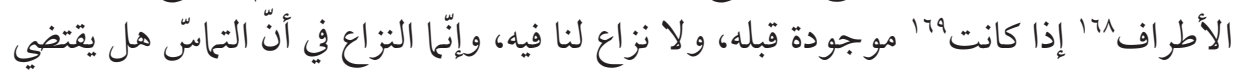

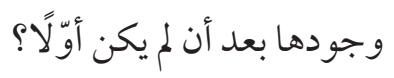

وإن أخذوا تلك المقدّمة إلزامية فنقول: ما ذُكر في معرض الدليل تنبيه على وجود الأطراف، لا

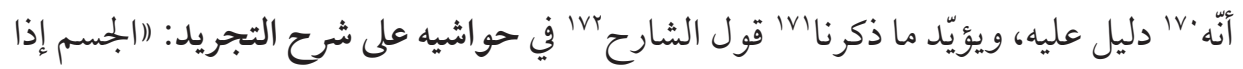

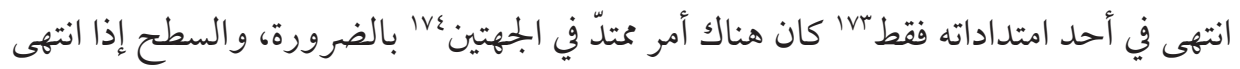

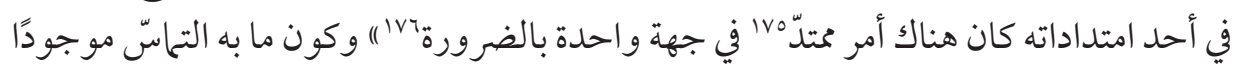

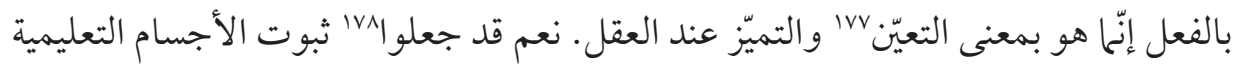

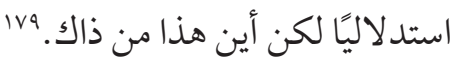
وقال في المحاكحات بعد أن بالغ في أنّ اختلاف الأعراض لا يوجب قسمة خارجية في الأجسام:

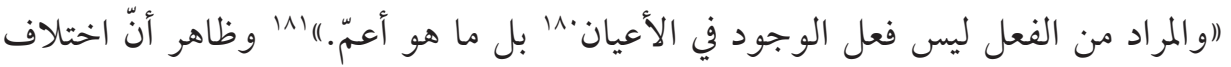

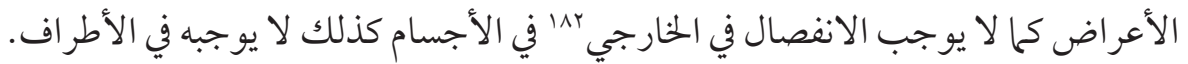

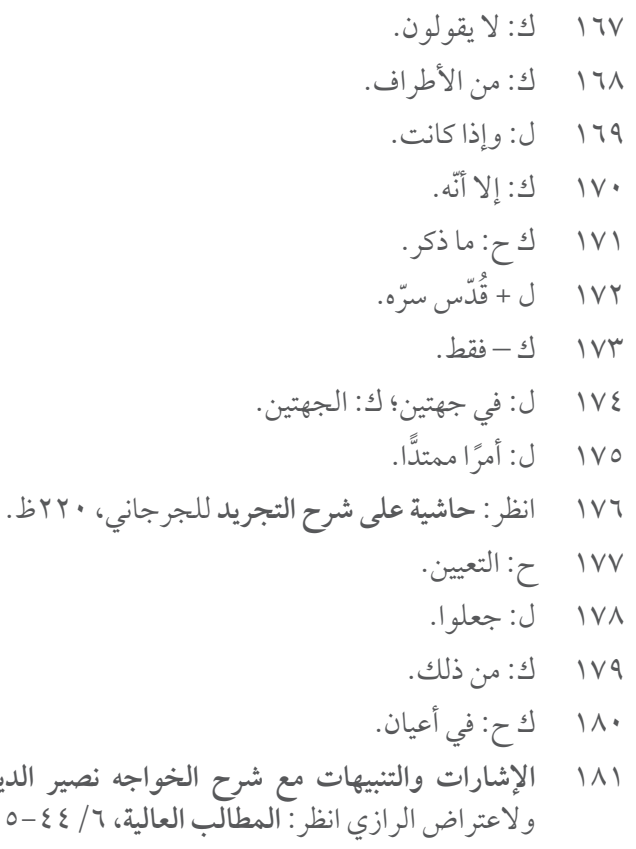

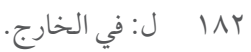




$$
\text { وقال في دليل تخلّل السكون بين كلّ حركتين مستقيمتين: }
$$

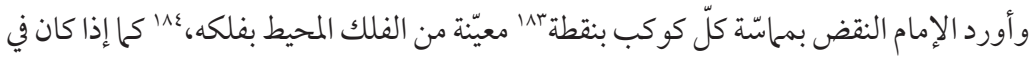

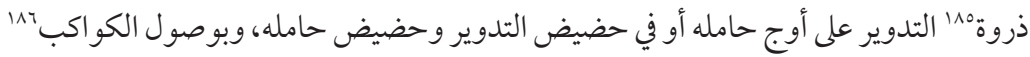

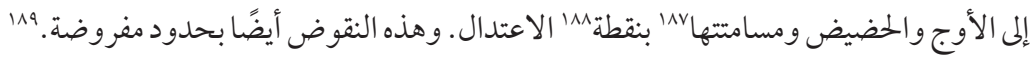
وهذا صريح في أنّ نقطة التماسّ غير موجودة في الخارج كنقطة المسامتة. بل19

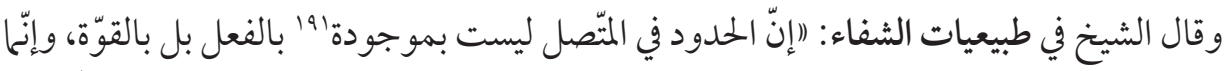

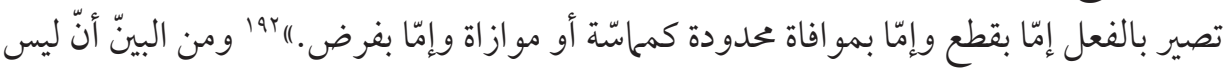

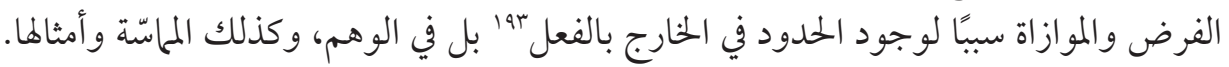

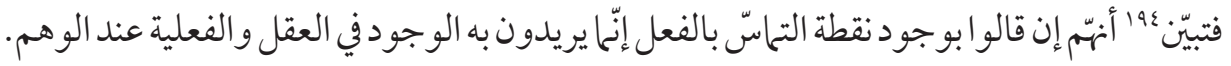
/ [ا / او ] ولمّا وضح أنّ تلك المقدّمة التي يبنون دلائلهم عليها لا يمكن أن تؤخذ برهانية ولا إلزامية. فأقول: إذا ماسّت الكرة سطحًا مستويًا فالتماسّ في الحقيقة ليس إلا لسطح 190 الكرة بنفس ذلك

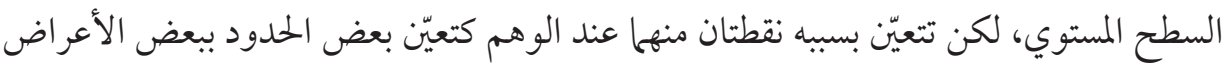

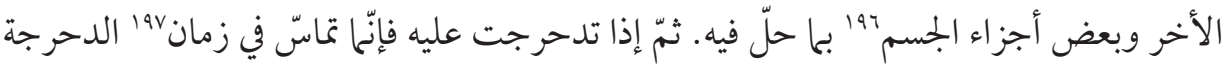

$$
\begin{aligned}
& \text { rی1 إل لنقطة. } \\
& \text { عها إل ل: لفلكه. } \\
& \text { 1/10 ك: ذروة. }
\end{aligned}
$$

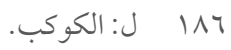

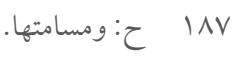

$$
\begin{aligned}
& \text { إ ل ل لنقطة. } \\
& \text { 1199 الإشارات والتبيهات مع شرح الخو اجه نصير الدين الطوسي والمحاكمات لقطب الدين الرازي، ب/ 199 . } \\
& \text { 19. } 19 . \\
& \text { 191 } \\
& \text { r } 194
\end{aligned}
$$

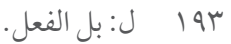

$$
\begin{aligned}
& \text { 19 إ: وتبيّن. } \\
& \text { 190 } 190 \\
& \text { 197 } 197 \\
& \text { 19V ل ك-5مان. }
\end{aligned}
$$


أيضًا بنفس السطحين، لكن يتعيّن ويتميّز في الوهم بسببها،19 خطّ مستدير 199 في الكرة ومستقيم في

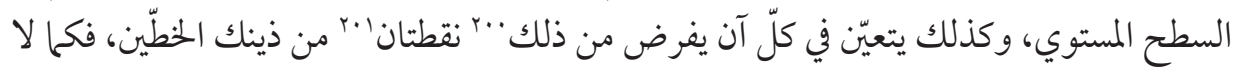

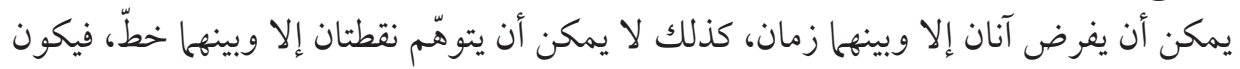

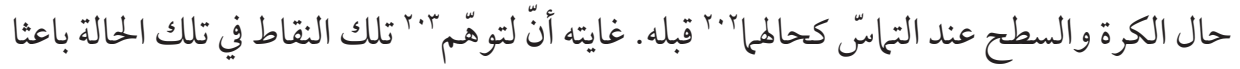

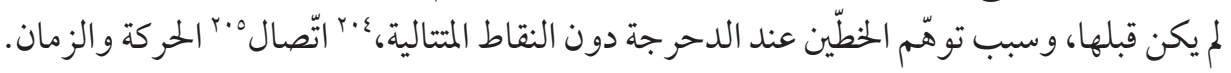

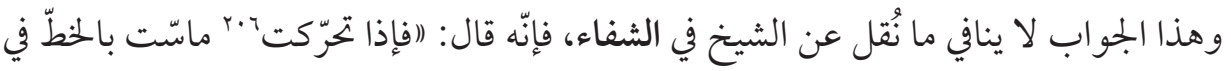

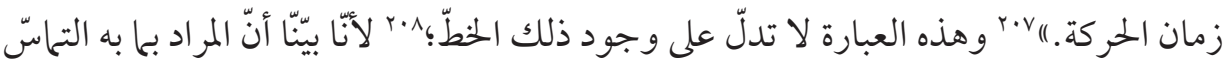

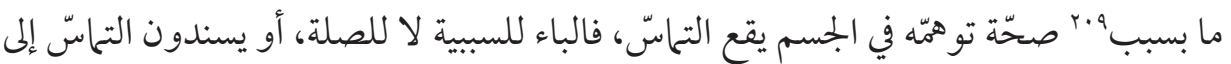

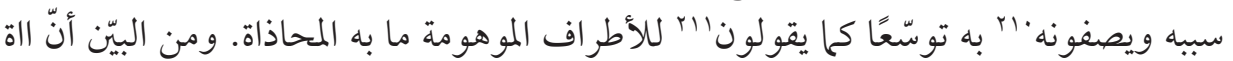

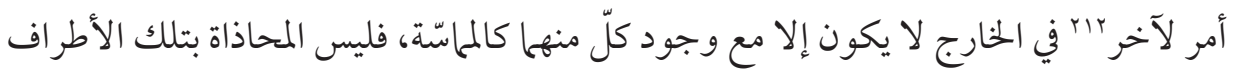

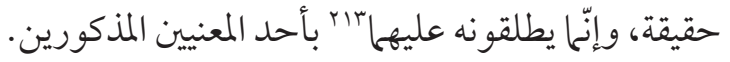

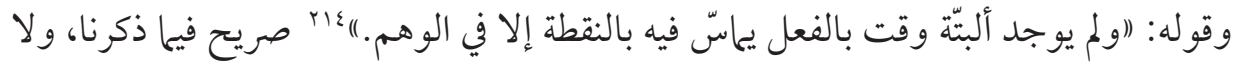

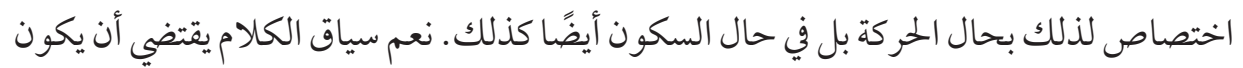

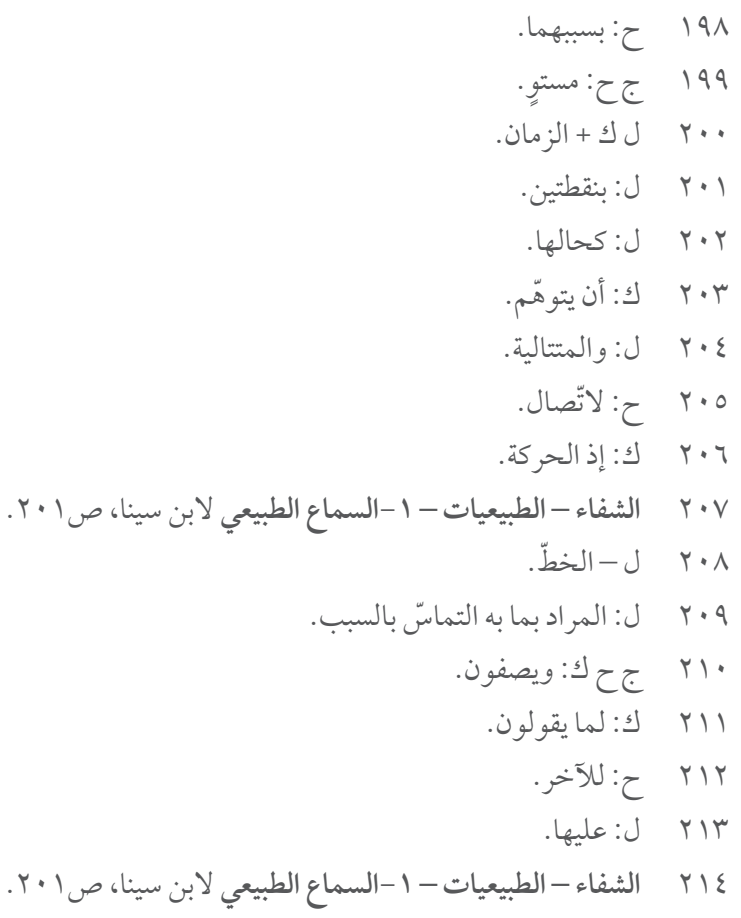




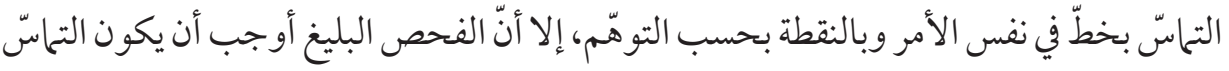

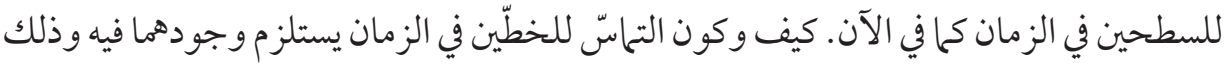

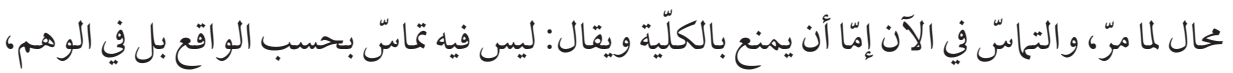

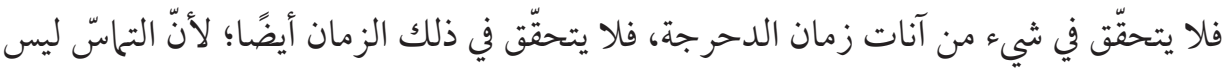

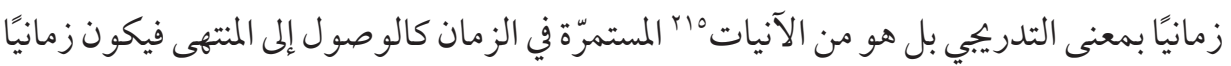

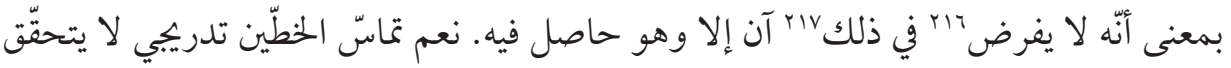

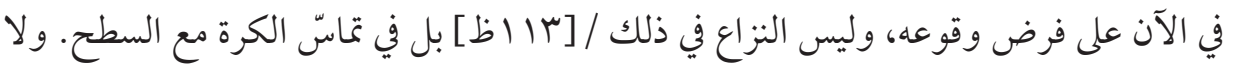

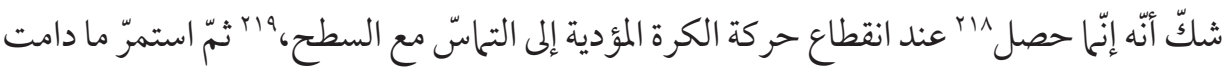

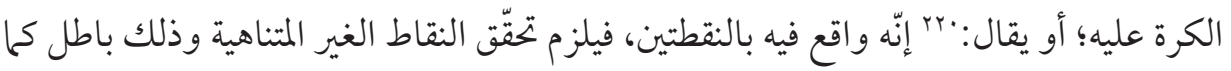

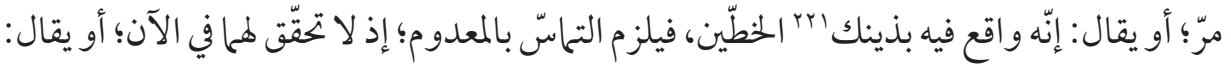

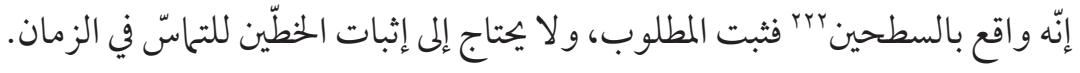

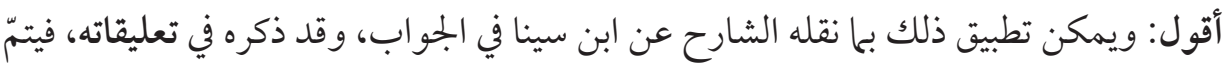

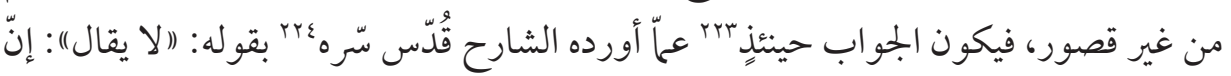

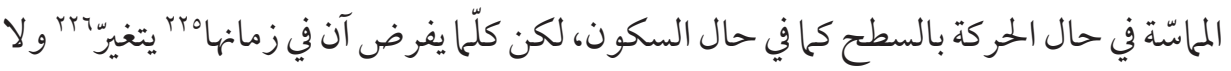

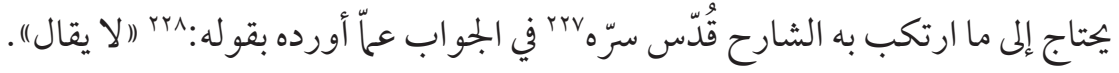

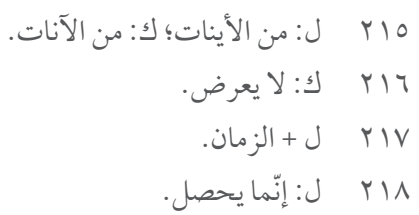

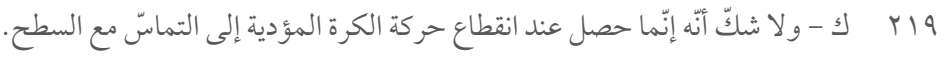
r.

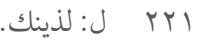

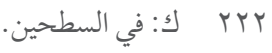
r

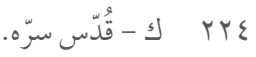

דro

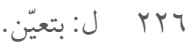
N

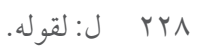




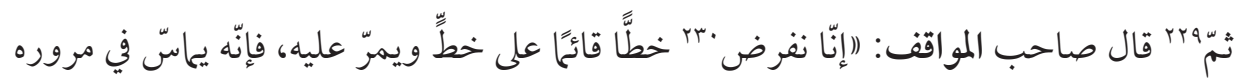

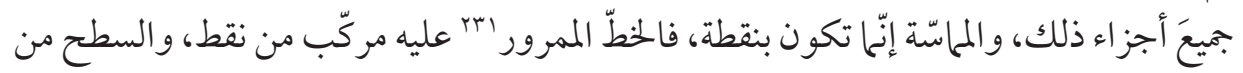

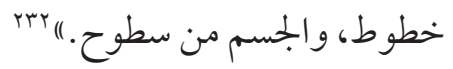

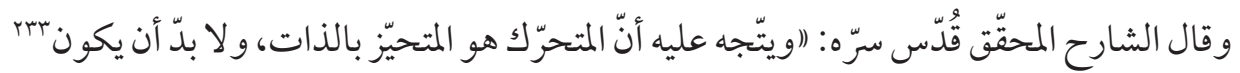

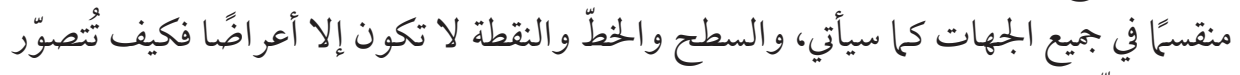

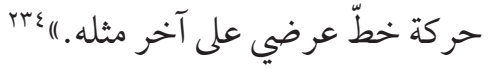

أقول: لا يتوقّف غرض المصنّف على أنّ الخطّ متحيّز بالذات فإنّ قيام خطّ على آخر ومروره عليه

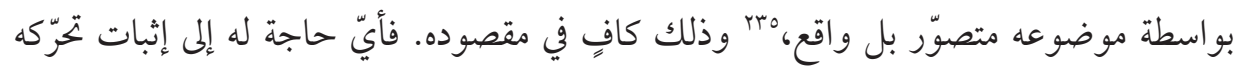

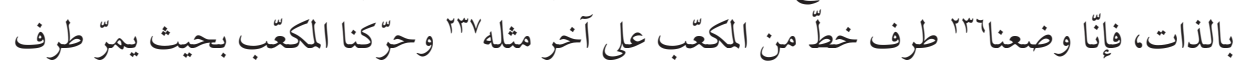

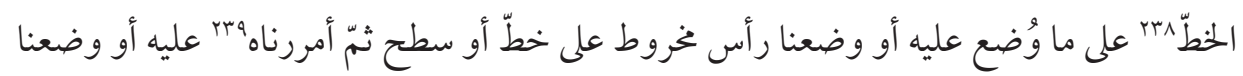

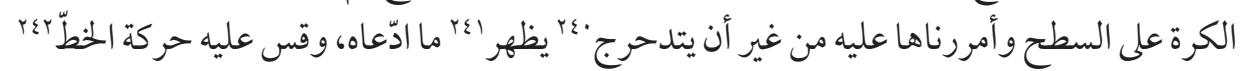

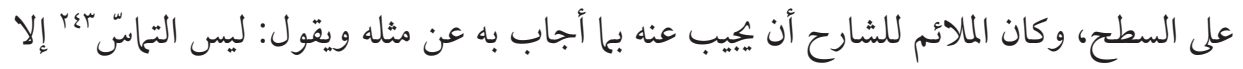

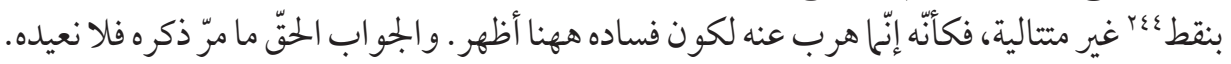
تمّت الرسالة بعون الله الملك الوهّاب

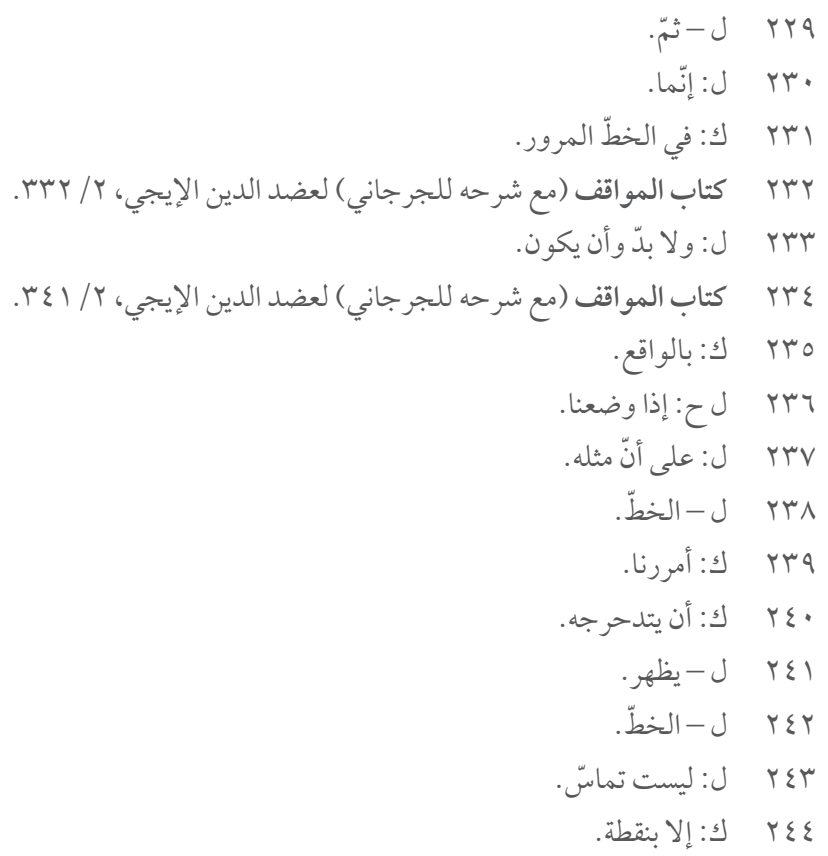




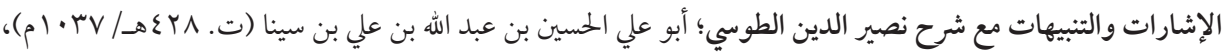

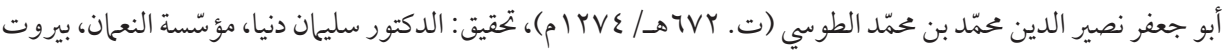

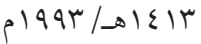

الإشارات والتنبيهات مع شرح الخواجه نصير الدين الطوسي والمحاكحات لقطب الدين الرازي؛ أبو علي الحسين بن عبد الله

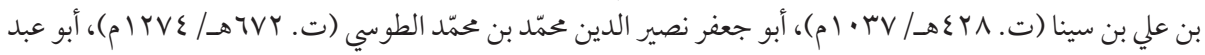

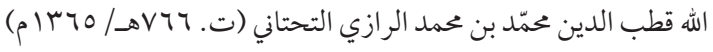

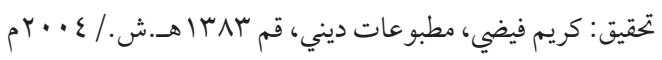

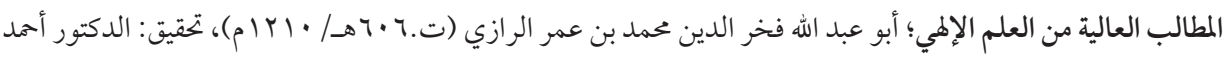

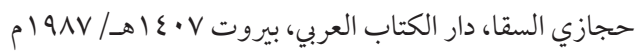

تحرير الأكر لثاوذوسيوس(الرسالة الثانية في مجموع الرسائل)؛ أبو جعفر نصير الدين محمّد بن محمّد الطوسي (ت.

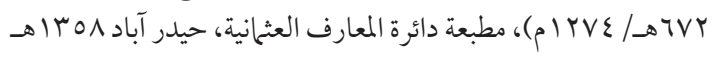

تحرير الكرة المتحرّكة لأوطولوقس (الرسالة الثالثة في مجموع الرسائل)؛ أبو جعفر نصير الدين محمّد بن محمّد الطوسي (ت. آل

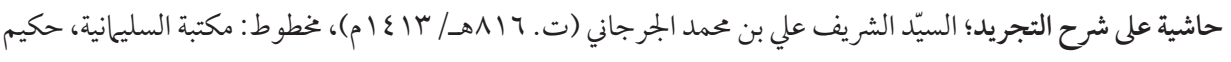

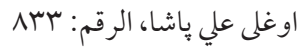

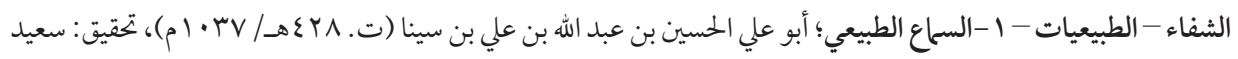

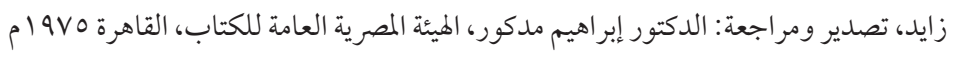

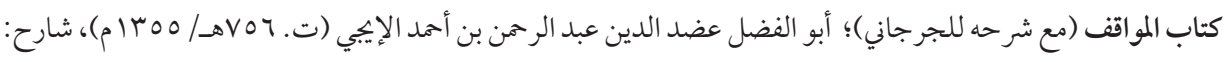

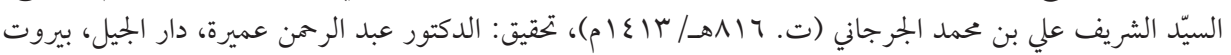

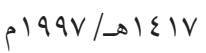




\title{
D. Translation
}

\section{TREATISE ON THE INDIVISIBLE PART}

\section{Mu'ayyadzāda 'Abd al-Raḥmān Efendi}

\author{
In the name of Allah, the Most Compassionate and Most Merciful. \\ From Him we ask for help.
}

The author of al-Mawāqif [al-Jurjānī] said in the "Chapter on the Indivisible Part": "Let's assume that a sphere is touching a flat surface. What makes contiguity is not divisible; otherwise, it is either divided in one direction, which is the line, or in many directions, which is the surface. But in this case, the sphere is not a sphere. We also assume that all parts roll into contact with the surface, and in that case, all parts will be undivided."

The shärih, muhaqqiq, and scholar [al-Jurjānī], May Allah make a good treat in heaven, said: "Ibn Sinnā replied to this: 'When the sphere touches the surface at some point, it may come into contact with a divisible time and a divisible movement at another point. Also, this point is not adjacent and contiguous to the first [one], for if it were it would overlap with it because continuity between two indivisible things can only ocur through the entire overlap between two touchpoints. This is the case for other points between which contiguity took place. Thus, neither the sphere's perimeter nor the flat surface are compounds of [those] points that follow each other."

[Ibn Sīnā:] "It can not be said: 'According to this, contiguity on the other point will only occur after movement, and in the state of motion there will be contiguity. So, if the contact happens at the first point, then the sphere rests in the time of motion. If the contact is at a moderate point between the two points, then there is a situation that will reverse the assumed provision, and we [will] carry on the debate to this midpoint. Then, in this case there must be no vehicles between the two points of contiguity, which requires that the points come in succession." Because we say: "Even though the contiguity on the first point occurs at one time, it keeps continuing its succession during the time of the rolling motion, which leads to contact at another point. The first contact is eliminated as soon as this second contact is realized. So, every contact that happens on a single point both occurs and 
continues to exist at a single instant. This situation is not contrary to the sphere's continuous movement, as it is clearly understood from the correct imagination.

[Mu'ayyadzāda:] I say: "The continuity of touch at one point is invalid (bāțil) in terms of following directions."

First: It was proved in the first article of Kitāb al-Ukar that when the sphere comes into contact with a flat surface, the diameter (quțr) resulting from the touchpoint is vertical to this surface. This diameter either moves or does not move at the time of the contact's continuation at one point. In the first case, this diameter cannot remain vertical or a right angle should be part of another right angle, because the diameter was assumed to be vertical. Therefore, this is a contradiction. In the latter case, the rolling motion should be interrupted. However, it was assumed that the sphere was rolling, and so this is also a contradiction.

Second: It was proved in the work of al-Kurat al-Mutaharrika that when a sphere returns at constant velocity (mu'tadil), all of the points on its surface form proportional arcs to each other in equal time and in corresponding parallel orbits. If the contact that occurred at some point had continued in time - for example, at a certain time like an hour - then the relation of this arc that the point passed on to the orbit of that point was supposed to be smaller than the arc of another point that passed on in the same hour to the orbit of that point, because unlike other points, the point of touch does not leave its position during any part of this hour. If it is accepted that one of the points does not move, in this case because the point of touch occurs after each other, then the [sphere] will not move during the entire period of rolling. In parts of these rolling times, there is no part for the continuation of contact at any time. So, this is clearly invalid.

Third: If a certain point of contact persists at the time, then this point can never be separated from its position at this time of contact and will not be polar for the sphere's circular movement. Otherwise, if it were polar, then the sphere would revolve around its own axis and would not leave its own location. However, it is assumed that the sphere is rounded, and so that is also a contradiction. [In case this point is not polar,] it is also necessary to stop a point outside the pole of the rotating sphere, which is likewise invalid.

Fourth: We draw on a sphere a large circle that passes through its two touchpoints. Then we assume that the sphere moves on a flat line on this circle and surface and say: "If the contact on the first point persists in time until contact occurs at the second point, and if another contact occurs in one of the points that 
are assumed to be in a limited arc with these two points, then the sphere must contact the surface at many parts. This is invalid. If [there is no such contact] and this arc is parallel to this line - it was assumed that this arc did not come into contact with this line - either the sphere cannot be a sphere or this surface is not flat. This is a contradiction. When the arc is not parallel to the line, the [sphere's movement] is either a leap (țafra) or the rounding should not happen in this circle. This is a contradiction in the same way.

Fifth: Each point which is assumed between two touchpoints in a limited arc with these two points are closer to the surface than the second point of touch. A point closer to the first point is closer to the surface than a point that is farther away from the first point. When the closer point does not reach the surface, the farthest point also cannot reach the surface in such a way that wemove all of them to the surface by a single movement. Since there is no point in this arc that does not come into contact with the surface, it is not possible for the contact to be made with non-successive points and the continuation of contact at a single point in time. This is what we mean.

Sixth: If the touchpoints [in the same arc that is limited by the mentioned points again] have not moved from their locations, but before they were able to complete a return due to their inactivity during the time of contact, then they had completed their rounds during their movements. In this case, [ which the touchpoints that the big circle transits on them had not yet been completed a tour] other points that differ from these touchpoints must have not completed their tours. But they were assumed to have completee their tours. This is a contradiction.

Seventh: The angle between the sphere's belt (mințaqa) and the straight line on the surface does not accept to the shrink, and so we cannot assume that an angle smaller than the first one occurred between this circle and this line. Otherwise, a right angle would be part of an[other] upright angle. The continuity of the touchpoint would, along with the movement of the sphere, require it. This is a contradiction.

Eight: If the touch at the first point had continued until contact was made in the second one, and if it were eliminated at the moment of contact with the second [point], then in that moment there is either only one point between the first point and the surface, which clearly requires the succession of three points, including the surface, the sphere, and the point between them. [Or, between the point and the surface] there are multiple points, which requires the sphere to move one distance in one instant, which is impossible. The overlap among distance (masäfa), time, and movement is required. 
As for the famous doubt, it is: When the sphere moves, passing from one end to the other, on a flat surface, each assumed point of contact between the movement's beginning and end constitutes one of the boundaries of the sphere's distance. As long as the moving object keeps moving, it cannot remain at one of the limits of its distance for more than an instant. How could this happen, given that the form of movement between the start and the end is intermediate? In other words, the limit that the moving object assumed at the moment of the move has no before or after.

It is necessary to prepare an introduction (muqaddima) to describe it as it requires, which is as follows: The falāsifa (qawm) classified occurrence (husūūl) as [1] gradual (tadrijī), which is a continuous entity that overlaps with time like movement, [2] momentary (daf'i), which occurs only in instant or in an instant with the time, or [3] (daf'i $/$ ghayr tadrijī), which was meant to overlap with it but occurs at this instant assumed in that time, not at the end of it. They said that the [final] one is an instrument between the momentary and the gradual, which are used in both directions.

Muhaqqiq al-Ṭūsī added a momentary occurrence (husṣūl) to the first session [2a] in the former sense. He divided the third session into "it exists in time and also ends" - which is the second session of the momentary hușūl in the former sense - and [2b] "it exists in time but does not end" - which is the third session in the previous divisions. There is no debate on such a division. For this reason, sometimes you will hear them by saying, "The end of the arrival (wușūl) is momentary ( $\bar{a} n \bar{\imath})$ and sometimes it is temporal." [In fact, these words] mean the same. As the shärih and muhaqqiq [al-Jurjānī) explained in various chapters of his books, they said: "It is momentary occurrence to reach a moving any one of the boundaries of the distance in the sense of momentary occurrence." They did not explain the issues that should be proved because they are clear enough.

I say: "This is the explanation: If it was not momentary occurrence to reach any limit, [1] it would either be gradually - and in this case, the boundaries of the distance would have to be divided into its extensions - or [2] not gradually. This is also invalid whether it is in the moment and in time or only in time, because if hușūl persists at any time on a particular border, it would have to stop at this border, since [1] no other ones would be moving at one of the boundaries of the distance at this time. But we hsf assumed that it was still moving. [2] Or, in the same way, the moving object would have to be at another boundary, which would require the combination of the parts of the movement and its boundaries. Both of these are impossible." 
In another way: "If an object moves constantly in time, it is contrary to the assumption that this is the time of rest. If it is the time of motion, [this movement] must either be [1] at this limit - which had not yet arrived, but was assumed to have reached - or [2] through this limit - which is invalid, because this requires that the boundaries of the distance be divided in their extensions - or [3] [starting] from this limit, which is also invalid because the movement [emerging] from an assumed beginning is a mediation (tawassuț) between this beginning and the end; it cannot come together with the accident of location (kawn) in here. They also said that the end of the arrival (wușül), starting at a border of the distance, is temporal, just as it was in the third session. If it was gradual this limit would have to be divided, and when it was momentary, the moments would come in succession. Likewise, it is understood that the arrival will occur at the moment.

When this is thoroughly understood, we say: "If the sphere is rounded on a flat surface, each touchpoint between the beginning and the end of this rolling is one of the boundaries of its distance. The sphere's contiguity to that point is arriving to that limit and the cessation of the contiguity to that point is arrival of this particular border by leaving through another limit. It is understood from all of this information that the movement on each border cannot meet with the location (kawn) here and, if it precedes [the arrival] with an essential priority, then the cessation of movement creates a temporal association. The part and the instant cannot be assumed at this time before the end of the arrival, and thus movement cannot be realized and each point cannot come together with an arrival toward another boundary. The meaning of their words: "The end of the arrival is only with movement and gradual [hușül]" is that the arrival depends on the motion and falls behind it with essential posteriority, which is not contrary to the occurrence of movement at all times of arrival. It is required if the temporal lateness happens gradually in the aforementioned sense, which is not because of the issue we have described before. Yes, it happens later temporally from the movement that leads toward the arrival, but it does not harm what it meant, because the end of the contiguity is at another time and at another point. What this means is: "Another point in the moment of extinction (zawāl) cannot be assumed, without putting together that cessation in that instant with the contiguity to another point," as was mentioned before. Between each point (i.e., the second point) where the end of contact at the first point meets the contiguity and first point, there is a distance in which the sphere moves between the instantaneousness of the contact in time. This first contiguity does not proceed in the moment of movement; on the contrary it ends, as was mentioned earlier. So until the moment of contact occurs at another 
point, any assumed point will not be sustained. Yes, if the contact at the first point does not end but occurs in the moment of contact wtih another peculiar point, then the previous contact must continue until the next touch occurs. This is possible only if there is a certain limit for distance and time; however, it is impossible to assume this limit for anything else. Thus, it is revealed that the end of the contact occurs in motion and that the gradual occurrence does not require perpetuity of the contact at the time of movement. On the contrary, it has occurred along with the movement in time and thus has been concluded to desired result (mațlūb).

I say: "Thus, the estimated issue is eliminated: "There is a definite distance (bu'd) between each point on the sphere and the surface, except for the touchpoint. The contiguity at one point ends when the second occurs. The contiguity of a second point also occurs only when it moves along the distance between the surface. So the contiguity continues at this time of movement. Otherwise, the act of rolling canot be realized without contact." So we say, as it turns out that the end of the contiguity will not happen at the moment, his sentence that "Contiguity does not end at the first point unless the second point arises" cannot be true.

Since the assumed time is limited by the instantaneousness of both contacts, it is also part of its expiration time and therefore will not be the time of the first contact's perpetuity. At this instant assumed in this time, contact occurs with the points that are assumed to be between these two points. The first contact does not continue at this time; it is even eliminated. By that way, this also resolves the confusion of some virtuous people (fudalä') about the "occurrence of the movement in any boundaries of the distance and in the sense of intermediary in any instant," because, as was mentioned earlier, movement does not occur at the beginning and the boundaries of the distance, or it should be achieved without movement to reach this limit from the beginning. When it is manifested that what is happening in time -not its extremes- is also a kind of occurrence (hușūl) and the movement is also from this kind of husūl, it is also understood that there is no instant in the time of movement allocated for its emergence. [We say this] because between each boundary and its ends, which are assumed in time, it is possible to assume the infinite boundaries in which the movement takes place, due to the continuity of time and the nature of the movement that accepts infinite division. Likewise, there is no limit on the distance, as it overlaps time and accepts infinite division.

When it is proved that the successive points could not have caused contact, then let's begin to examine what caused the state of rolling to occur. 
We say: [1] It is not possible for contiguity to occur with consecutive (mutatālī) points. Although the points occur one after another according to the renewal and interruption of the contact, it is not a consecutive and consequent (mutarattab) thing. [This is so] because it both necessitates that one considers the consecutive points and also requires the successive moments, even one of which is sufficient to prove the atom. [2] As is known from the answer of the famous doubt (alshubhat al-mashhüra), contiguity does not occur with a flowing point whose individuation (shakhșiyya) continues from the rolling's beginning to its end and its some assumed accidents substitute (tabaddul) every instant by its individuality and with the perpetuity of its essence, because this requires the point move by itself, which is impossible. If both are to be handicapped, the impossibility here is better understood than the contact point in the sphere than the contact point on the surface. [3] The contact does not occur with two lines, one of which is linear (mustaqim) and the other circular (mustadir) and their pieces are found together $(q \bar{a} r r)$. Because there is no line in the sphere or on the surface, contact cannot cause these lines to appear on them. We certainly know that the thing that provides the contact as well as its stuation after the contiguity's cessation is the same [as that] before it. Therefore, there is no line after contact, as it is not before contact. When these options are invalid, it becomes apparent that the parts of the contact are not together at the same time (ghayr qärr) with two lines, which is clearly understood. Because the contact, which leads to the emergence of something that is not before, and the movement of the sphere followed by the contact is the thing that has no actual parts and its components do not come together in reality (ghayr qärr) and it is also a single-continuous in the nafs al-amr (matter of fact) then the contiguity must be something like this. That is the only line at which their parts do not come together in reality.

The Sheikh [Ibn Sīnā] has put forth a long chapter in his al-Shifä' to prove that movement and time do not have first parts. He did this to prove that what provides contiguity is the state of movement, which is constant, and that the first part of the time was not formed by the first part of the movement. Let that piece be a point! He made that claim after he said: "The sphere's contact with the surface and the line does not need to be just a point, no matter in which case, but it is in the states of permanence and rest. When the sphere moves, it touches the line at the time of movement. The time at which the contact with the point occurs is only in the estimation, because this contact can only be imagined at the moment, and the moment has no actual existence." This answer can only be considered after ignoring the part, which is where the debate is, because that is sufficient to declaring to the 
hakim (the philosopher) [to ignore the part]: "Why would it be permissible for the state of movement to provide the contiguity, which is a continuous thing, and its parts do not come together in reality like the movement? The final purpose of the issue is that he believes that there may be a possibility of [contact with the point].

I say: In this answer, there are two problems (ishkāl):

The first problem is that, as the sharif and muhaqqiq explains with the benefit of the words of the Imām [al-Rhāzī] found in Sharh al-Ishārāt, the existence of something similar to that is not reasonable, how would it be? If that were possible, it would permit the existence of movement in the sense of time and transition. Besides the Sheikh refuted it in his al-Shifä' as follows: "If it is meant by movement that is a reasonable and constant thing for a moving object between the beginning and the end, it is clear, it can't happen in anyway while the moving object between the beginning and the end. On the contrary, it is believed that this happens through the occurrence while moving at the end. There is no provision of that reasonable constant thing here (between the beginning and the end) having any real occurrence in the reality. On the contrary, it is a circumstance that has no essence, which is existence in the concrete world (a'yān)

Second problem: "As the sphere has contact with the line at the time of movement, there is a contact with that line in every moment that is assumed in time. In addition, the thing that provides contiguity should be present at the time [just] as it should be present in the moment, which is the only point. For this reason, although it is limited between two delimits, in this line whose parts do not come together, there must be an infinite point that has a regular position in the nafs al-amr.

In relation to the words of [Ibn Sīnā]: "The actual time in contact with the point is only in the estimation. This only happens by thinking of the moment, but the moment has no reality." I said: "The occurrence of the contiguity in the instant, according to the nafs al-amr, whether this instant is real or not, is sufficient to prove that point, just like the happening of contiguity at the time of movement was enough to prove that the line and the estimation of the time and movement did not damage it. Also, it cannot be said: "This problem also applies to the line, [for] it is possible to assume an infinite point on the line."

I said: Estimation cannot afford to bring infinite situations into the intellect. Because of estimation, the conditions that emerge from the potential to the actual are finite in all cases. As for the intellect, it can comprehend these infinite points 
only in a way that encompasses them all and universal manner. As explained in the relevant part, infinite things do not come from the potential to the actual by assuming the intellect. Regarding our review here, when the contact at the moment is the cause of the body of the moment, and the contacts that occur in the instants are infinite in terms of an eternity of the instants, then the points in the external world happen infinitely in the same way.

I say: The true answer, which is not possible to escape, here requires the preparation of a premise, which is: "This evidence and most of the [other] proofs are based on the permanence of the part/atom. Accordingly, it is necessary to have a reality of the thing that provides contact, whereas that is not the case [here]. The [proofs] that they mention to prove the part, such as [1] there is no doubt about the reality of objects and they are in contact with the entities divided by width and length, not in depth, or that interpenetration is required between two things that are divided in depth or [2] the contiguity happens with two parts between two lines, not with two objects." In that case, we carry on the debate of these two parts and their non-division, so that this division does not regress infinitely (tasalsul), but rather results in a thing that is indivisible in depth, which is the surface. This is why the reality of the surface will be proved. Then the two existent surfaces come into contact with something that is divided not in width - but as you know, one of two states is required - which is the line. Thus, the existence of the line is proved. Then the two existent lines come into contact with something that is located and never undivided, which is the point. Here is the debate, because if it is meant by the existents that the assumed contiguity took place, the most suitable thing for the contiguity, we prefer to have the essences of the bodies (line-surface) divided in the directions.

His claim, "Otherwise, interpenetration must occur" is unacceptable (mamnū), because interpenetration requires that the contact be attached to each one of the parts or to some of them. Why would it not be permissible to assume [this] for the all body in terms of its entirety rather than each part or just some of them?

In summary: Due to the fact that a surface is an object, it attaches only to the body, not to all or some of its parts, because the division of the body in directions does not necessitate the division of the surface, because of its spread only in two directions, not all. As such, it is also possible to assume that it contacts in terms of it is a body, not with all parts of it or some of them in a way that will cause the abovementioned two problems to arise. Like this, we also say this in the contact of the surfaces with lines and the contact of the lines with points, and one needs 
evidence to reject it. The intellect's determination of some aspects of the object for contact in the sensory signal is not an obstacle to the contiguity's attachment to it. This is caused by the spread of the object only in some aspects, such as at the ends. Because it spreads in some directions in the same way as does the sensory signal, it is determined in these directions and not in other ones.

I say: If "the thing that provides the assumed contiguity" means "the most suitable thing for the contact," and this denial (man) could not be meant for the evidence, then the permanence of the surface in the body requires the permanence of infinite surfaces that attach theselves to each other, or [all these surfaces] must come to an end in the surfaces par soi (jawharì). We say: "The thing that the surface is attached to (ma'rū for that requires either division of the surface in directions or the attached thing must be the part of it's assumed parts that are attached to. In that case, the debate is carried on there and does not regress infinitely; rather, results in the surface par soi, which is the surface." Likewise, we say that this surface either goes on forever (tasalsul) or that it ends on a surface par soi. This is the case with the status of the line and the point; however, it is impossible to say that about them too. If "the thing that provides the contact" means "the vehicle that ensured the permanence of the contact in the subject of the attachment," we prefer that it not be an existing circumstance that co-exists either with the object or with part of it, or that it occurs with the body in the external world. On the contrary, the vehicle here, it is the possible to assume the surface in the object. So if this property (i.e., the surface) is not in the object, then the contact is not attached to it. Compare the contiguity of two lines with one point, and the contiguity of two surfaces with a line! Therefore, characterizing the object or something else in the nafs al-amr with the mental concepts, or the possibility of our thinking of some situations in the object thanks to the true consideration that overlapped the nafs al-amr, is not a condition that can be denied. Is it not understood in terms of the relationship of light to Earth that Earth is in the opposition of the light-giving objects and that the relationship of different colors and lights to the adjacent object is only possible because we are able to imagine that thing in the object according to the true consideration? Even if the object did not have this characteristic, the opposite things in one moment were not attached to the object, since the contact is not from the external entities, but from the relations that are specific to those things that have a location.

I say: A person who says that the cause of contiguity must be in the external, why not say that the cause of the contraposition (muhāadhāt) will be in the external, 
with a very small modification and by presenting evidence? Yes, contiguity can occur between the extremes if they were before the [contiguity], and there is no debate in this regard for us. The main debate is, "Does contiguity require these extremes later if they were not before?"

When they obtain this premise as an argumentum ad hominem, (ilzāmī) we say: What is mentioned in the position of evidence is a caution concerning the existence of the ends, or is not evidence of contact. What the commentator said in the Häshiyat Sharh al-Tajrìd also corroborates the issue that we mentioned: 'If the object only ends in one of its directions, then there is something (i.e., the surface) that necessarily must extend in both directions. If the surface ends in one of its directions, then there is something (i.e., the line) that also necessarily must extend in one direction.' Therefore, the actual reality of the thing that caused the contact (i.e., line) means the determination (ta'ayyun) and the distinction (tamyiz). Yes, they made the permanence of the mathematical bodies inferential, but are they the same thing?

[Quṭb al-Dīn al-Rāzī] after saying in al-Muhākamāt that the differentiation of the attributes does not require an external division in the bodies, went a little further and said: "What is meant by the action is not an act of existence in the concrete world ( $a^{\prime} y \bar{a} n$ ), but a more general thing." It is clear that the differentiation of the attributes require neither a discontinuity in the external objects, nor a division at the ends.

As for the evidence provided by [Ibn Sīnā] for locating the rest between two linear movements (rise and fall), he said: "The Imām demonstrated the invalidity of this view by following examples: i) each star contacts with its own celestial spheres to the certain points of the celestial sphere of Atlas, which, as a matter of fact, is also the same for the contact of the epicycle while it was in the apogee to the apogee of its carrier celestial sphere or the contact of epicycle while it was in the perigee to the perigee of its carrier celestial spheres - ii) reaching of the stars to the apogee and perigee iii) and projecting stars toward the point of the equinox." These refutations also occur with the assumed limits. This is evident about the contact point, such as the point of encounter (musāmata), that does not exist in the external. ${ }^{1}$

The Sheikh said that in the chapter of Tabī'iyyāt of al-Shifä': "The limits in the continuous [entity] are not actual but potential. These limits become actual 
either with a cutting (qat) or with limited conformance (muwāfāt maḥdūda) like contiguity and parallelism (muwāzāt), or with the assumption (fard)." It is obvious that assumption and parallelism are not the reason for the boundaries to be actual in the external, but in the estimation, and that contiguity and its counterparts are the same. So when they said that the contact point actually existed, it turned out that they meant existence in the intellect and actuality in the estimation.

When it clarified that this precise that they depended their evidence on, it can't be accepted neither demonstrative nor obligatory, I say: "When the sphere touches a flat surface, the real contact is only the contact of the sphere's surface with this flat surface. However, due to this contact, two points become evident in the sphere's surface and the flat surface in the estimation, just as the determination of some limits by some parts of other attributes and some parts of the body by the thing that resides in the body. Then, when the sphere is rounded on the surface, it also touches the two surfaces itself in the same way at a rolling time. However, due to this rolling, a smooth circular (mustadir) line in the sphere and a straight (mustaqim) line on the smooth surface become apparent and differentiated (tamayyuz). Thus, at each moment assumed in that time, the two points are distinct from these two lines. It is also impossible to think about two moments that have no time between them, just as it is not possible to assume two points that have no line between them. Therefore, the condition of the surface and the sphere in the moment of contact is like that before the contact. And the aim ( $g h \bar{a} y a)$ of this, thinking of these points as an incentive ( $b \bar{a}$ i $i t h)$ that was not before. The reason for thinking about the two lines, not two successive points in the time of movement, is the continuity of time and movement."

This answer is not contrary to the information narrated from the Sheikh's alShifä'. He said: "When the sphere moves, it touches the [surface] with a line at the time of movement." This sentence does not indicate the [external] entity of this line, because we explained earlier that what is meant by the "thing that makes contact" is the thing that contiguity has found in the object, thanks to the imagination. The " $b \bar{a}$ " in the phrase [mā bihì al-tamāss] is not for the connection (șila), but for the causality. They also attributed contiguity to its cause and, as they used the phrase the "thing that makes parallelism" ( $m \bar{a}$ bihì al-muhādhāt), they describe it in order to expand the meaning (tawassu). It is clear that, the fact that something was in the encounter of another thing else in the external world due to the existence of both things as like as contiguity. However, parallelism is not really with these ends. However, they use one of these two meanings ascribed for them. 
He [Ibn Sinnā] said: "The actual time that the contiguity will be only in the estimation" is also clear, as we mentioned earlier. There is no specific situation to the state of movement, but it is exactly the same as in the state of rest. That is correct, because the context of the word (siya q) necessitates that contiguity be with the line in the nafs al-amr and with the point in the estimation. However, a serious investigation requires that the contiguity of two surfaces be the same at the moment. How can this be possible, for the occurrence of contiguity in time with two lines requires the existence of these lines at that moment, which, as was mentioned earlier, is impossible? In that case, the momentary contact is either completely rejected, and said: [1] "There is no contact at the time according to reality," and thus contiguity does not occur in any moment of the time of the rolling, and therefore at this moment. Because the contact is not temporal in terms of being gradual - as it has to be to arrive at the end - it is momentary occurrences (äniyyät) that continue in time. Thus, it is temporal in the sense that one cannot assume a moment in time without the occurrence of contiguity in time. Yes, there is no debate on the graduality of the contiguity of two lines and its not happening in a moment, according to the assumption of its incidence. Undoubtedly, contact takes place when the sphere's movement, which leads to contact with the surface, is interrupted, and then it continues as long as the sphere remains on the surface. [2] Or it is said that the contact occurs at two points on the surface. This is also invalid because it requires the accruals of infinite points, as was mentioned earlier. [3] Or contiguity is said to occur with these two lines, which requires contact with something that is non-existent, because it has no accrual in reality for two points. [4] Or the contiguity is said to occur with two surfaces so that the desired thing (mațlūb) is fixed and there is no need to prove the two lines for contact in time.

I say: "It is possible also in the answer to apply the issue that the muhaqqiq narrated from Ibn Sinnā. He mentioned this in his al-Talīqāt, and then the topic will be completed without any gap. Then the answer that the muhaqqiq [al-Jurjāni] responded with his sentence "It isn't possible to say" is as follows: "Contact with the surface on the state of movement is like that on the state of rest." However, whenever this moment is assumed at the time of movement, it will be changed, and, in fact, there is no need for the muhaqqiq (q.s.) to say "It is not possible to say" in the answer.

Then the author of al-Mawäqif [al-Ijji] said: "Let's assume a line that is perpendicular to a line and passes over it. This line touches all parts of that line in this progression. The contiguity here is done with a point, and the line that is 
passed over consists of the points. Thus, the surface from the lines and objects are composed of surfaces."

The shärih al-muhaqqiq [al-Jurjānī] said: "This following [objection] is directed against al-İji: 'Moving is spatial by itself and must be divided in all directions, as will be described later on. As the surface, line, and point are accidents, how can it be imagined that an accidental line moves on another one that is similar?"

I say: The purpose of the author [al-İji $]$ here cannot be attributed to the fact that the line is spatial by itself. The subsisting of the line on the other line through its subject and its progress on it can be imagined even if it is present. Then why is it necessary to prove its movement by itself? If we (a) put one end of the cube's line on another and then move the cube so that it passes through the line on the end of the line, or (b) place the cone's top point on a line or the surface and then forward it to the surface, or (c) put the sphere on the surface and forward it without rolling - all of these reveal the point that he claims. Compare that with the movement of the line on the surface! What is adequate for the author is that he respond to that objection just as he did it for the similar ones and say: "Contiguity happens only by the points that do not come in succession." He avoided this statement because its corruption was so obvious. We do not repeat the aforementioned correct answer here.

This treatise has been completed by the assistance of God. He is the Sovereign [al-Malik] and the Bestower [al-Wahhāb]. 